Avaliação do valor sistemático do Processo do I Urotergito em machos de onze espécies da subfamília Triatominae (Hemiptera, Reduviidae)

Tese apresentada ao Departamento de Epidemiologia da Faculdade de Saúde Pública da Universidade de São Paulo para obtenção do grau de Doutor em Saúde Pública. 


\section{AVALIAÇÃo do VALOR SISTEMÁTICO dO PROCESSO DO I UROTERGITO EM MACHOS DE ONZE ESPÉCIES DA SUBFAMÍLIA TRIATOMINAE (HEMIPTERA, REDUVIIDAE)}

LISARDO OSÓRIO- QUINTERO

Tese apresentada ao Departamento de Epidemiologia da Faculdade de Saúde Pública da Universidade de São Paulo para obtenção do grau de Doutor em Saúde Pública.

ÁREA DE CONCENTRAÇÃO: EPIDEMIOLOGIA

ORIENTADOR: PROF. TITULAR DR. JOSÉ MARIA SOARES BARATA 
Autorizo exclusivamente para fins acadêmicos e cientificos, a reprodução total ou parcial desta tese, por processos fotocopiadores.

Assinatura: hisond OSvio kinuthe

Data: $21 / 08 / 2002$

$$
4275312002 d x
$$


"Que ninguém se vanglorie do seu saber, nem despreze os humildes, pois estes sabem muitos segredos que Deus não revelou aos que têm fama de sábio".

Roger Bacon

(1214- 1294) 


\section{Dedicatória}

A minha filha Susana, por ter suportado as saudades geradas por minha ausência. 


\section{Homenagem}

Ao Prof. Dr. Oswaldo Pinto Serra, Professor aposentado do Departamento de Parasitologia do ICB/USP, a nossa homenagem pela identificação e revelação da estrutura do Processo do I Urotergito, assim como pelo estímulo e incentivo no prosseguimento do estudo desses caracteres. 


\section{AGRADECIMENTOS}

Ao Prof. Titular Dr. José Maria Soares Barata, pela orientação, apoio e sobretudo pelo carinho e amizade.

À Prof Nilza N. da Silva pela realização da análise estatística e pelo incentivo.

À Prof ${ }^{a}$ Eunice Aparecida Bianchi Galati pela troca de idéias, informações, amizade e incentivo.

Ao Prof. Dr. João Aristeu da Rosa da Faculdade de Ciências Farmacêuticas da UNESP de Araraquara, pela troca de idéias e informações e sobretudo pela amizade e incentivo.

Ao Dr. José Jurberg, componente da banca examinadora, pela sua contribuição em suas sugestões e critica pertinente ao trabalho.

Ao Prof. Dr. Delsio Natal pelo incentivo e amizade.

Ao Prof. Titular Dr. Almério de Castro Gomes, Chefe do Departamento de Epidemiologia, pelo incentivo.

Ao Prof. José Arana Varela, coordenador dos projetos de Microscopia Eletrônica de Varredura do Instituto de Química da UNESP, Araraquara pelo apoio logístico.

Ao Prof. Mario Zilense, responsável pelo laboratório de Microscopia Eletrônica de Varredura do Instituto de Quimica da UNESP, Araraquara pelo apoio logístico.

Aos funcionários da Comissão de Pós-graduação, Assessoria Acadêmica e Serviço de Aprimoramento da FSP/USP, Ângela Maria Pereira da Silva, Maria Aparecida Mendes, Renilda Maria de Figueiredo, Silvia Ivone Botelho, Marilene Rosa da Silva 
França e pessoas ligadas às áreas pela atenção dispensada, pela paciência e pelo apoio constantes.

Aos funcionários da Biblioteca CIR da FSP e pessoas ligadas à área, pela atenção, dedicação e costumeira disposição na prestação dos serviços.

Aos técnicos do Laboratório de Microscopia Eletrônica de Varredura (MEV) e processamento de imagens do Instituto de Geociências das USP, Isaac Jamil Sayeg e Douglas Vivona pela orientação e facilidades para a realização de imagens digitais.

Ao Sebastião Dameto, técnico de MEV do Instituto de Química de UNESP de Araraquara, pelo apoio na realização das fotografias.

Ao desenhista Daniel Flores pela revelação e cópias fotográficas.

Ao Cezar, funcionário da Seção de Informática da Sala Pro- aluno da FSP, pelo apoio técnico.

Ao funcionário da Secretaría do Departamento de Epidemiologia da FSP Valdecir, Rosana e Laurindo pela amizade, apoio e facilidade concedidos.

Aos colegas do Laboratório de Triatomíneos e Culicídeos da FSP, Walter Ceretti Junior, Paulo Roberto Urbinatti, Marcos Takashi Obara, pelo convívio, colaboração e amizade.

Ao biólogo Alberto Ricardo Papa pelo apoio na edição de imagens e pela amizade.

À Sara Elizabeth Palacios Sanchez, pela ajuda na digitação e sobretudo pela amizade.

À Betina dos Santos Ruiz Coelho pelas correções do Português. 
Aos amigos da Pós-graduação Alcides, Luiz Cláudio, Heliana, Vera, Ozinaldo, Nívea, Betina, Dilmara e demais colegas pela amizade, carinho e colaboração pessoal.

Ao PEC-PG-CAPES (Programa Estudantes Convênio- Pós-graduação-Coordenação de Aperfeiçoamento de Pessoal de Nível Superior), pelo apoio financeiro concedido.

A todas as pessoas que, de forma direta ou indireta contribuíram com o desenvolvimento deste trabalho, os sinceros agradecimentos. 


\section{RESUMO}

Osório- Quintero L. Avaliação do valor sistemático do Processo do I Urotergito em machos de onze espécies da subfamília Triatominae (Hemiptera, Reduviidae). São Paulo, Brasil; 2002. [Tese de Doutorado- Faculdade de Saúde Pública- FSP da Universidade de São Paulo- USP].

Objetivos. Avaliar o valor taxonômico da estrutura denominada "Processo do I Urotergito" (PIU) para a utilização na identificação de espécies de Triatominae, considerando parâmetros morfológicos e morfométricos. Comparar a eficiência da Microscopia Óptica (MO), da Microscopia Digital (MD) e da Microscopia Eletrônica de Varredura (MEV) na descrição das características morfológicas e ou morfométricas desse processo. Material e Métodos. Através de MO, MD e MEV partindo-se da observação direta, da fotomicrografia e/ou do desenho em câmara clara, estudaram-se machos de 12 colônias de triatomíneos procedentes de diversas localidades do Brasil, mantidas no insetário do Serviço Especial de Saúde de Araraquara (SESA), pertencente à FSP da USP. Foram observados cinco exemplares de cada amostra das espécies Panstrongylus megistus (Burmeister, 1835), Rhodnius nasutus Stal, 1859, Rhodnius neglectus Lent, 1954, Rhodnius prolixus Stal, 1859, Triatoma brasiliensis Neiva, 1911, Triatoma infestans (Klug, 1834), Triatoma pseudomaculata Correa \& Espinola, 1964, Triatoma rubrovaria (Blanchard, 1843), Triatoma sordida (Stal, 1859), Triatoma tibiamaculata (Pinto, 1926) e Triatoma vitticeps(Stal, 1859) Resultados. A análise morfológica do PIU permitiu observar diferenças significativas entre as espécies estudadas. Embora o estudo morfométrico tenha permitido definir atributos taxonômicos do PIU, tais como "Largura Basal do Urotergito 1", "Largura Basal do Urotergito 2", "Largura Apical do Urotergito 2" e “Comprimento do Urotergito 2", como parâmetros a serem utilizados na sistemática, a análise dos resultados não permitiu uma coerência com o padrão taxonômico tradicional da subfamília Triatominae, talvez pelo pequeno número de espécies trabalhadas. Conclusões. O PIU demonstrou ser uma estrutura útil na separação e identificação de espécies de triatomíneos. No estudo, considerou-se importante tanto a utilização da MO como a MD e a MEV. Recomenda-se particularmente a 
ampliação do estudo das observações morfométricas que deverão comparar e analisar um maior número de espécies.

Descritores: Triatominae, urotergito, taxonomia, morfometria, microscopia eletrônica de varredura. 


\section{SUMMARY}

Osório- Quintero L. Evaluation of the systematic value of the Process of the I Urotergito in males of eleven species of the subfamily Triatominae (Hemiptera, Reduviidae). Sao Paulo, Brazil; 2002. [Tese de Doutorado- Faculdade de Saúde Pública- FSP da Universidade de São Paulo- USP].

Objectives. To evaluate the taxonomic value of the structure, called "Processo of the I Urotergito" (PIU), for the use in the identification of species of Triatominae, considering morphologic and morphometric parameters. To compare the efficiency of Optic Microscopy (OM), Digital Microscopy (DM) and Scanning Electronic Microscopy (MEV) in the description of the morphologic and or morphometric characteristics of that process. Material and Methods. Through OM, DM and SEM, breaking itself of the direct comment, of the photomicrography and/or the drawing in clear chamber, male of 12 colonies of triatomine bugs originating of diverse localities of Brazil, had been studied. They had been kept in the insectary of the Special Service of Health of Araraquara (SESA) of the FSP of the USP. Five units of each sample of the species Panstrongylus megistus (Burmeister, 1835), Rhodnius nasutus Stal, 1859, Rhodnius neglectus Lent, 1954, Rhodnius prolixus Stal, 1859, Triatoma brasiliensis Neiva, 1911, Triatoma infestans (Klug, 1834), Triatoma pseudomaculata Correa \& Espinola, 1964, Triatoma rubrovaria (Blanchard, 1843), Triatoma sordida (Stal, 1859), Triatoma tibiamaculata (Pinto, 1926) and Triatoma vitticeps (Stal, 1859) had been observed. Results. The morphologic analysis of the PIU, allowed to observe significant differences between the studied species. Even though the morphometric study has allowed to define taxonomic attributes of the PIU, such as "basal width first urotergite", "basal width $2^{\text {nd }}$ urotergite", "apical, width $2^{\text {nd }}$ urotergite" and "length $2^{\text {nd }}$ urotergite", as parameters to be used in the systematic, the analysis of the results did not allow coherence with the traditional taxonomic standard of the subfamily Triatominae, perhaps due to the small number of species worked. Conclusions. The PIU demonstrated to be a structure useful in the separation and identification of species of triatomine bugs. In this study, the use of OM was considered in such a way important as the DM and the SEM. It's advised 
particularly extending the study of the morphometrics comments that will must compare and analyze a greatest number of species.

Keywords: Triatominae, urotergite, taxonomy, morphometry, scanning electronic microscopy. 


\section{Sumário}

\section{INTRODUÇÃO}

1.1. Vetores da doença de Chagas

1.2. Ciclo de Infecção dos Triatominae

1.3. Estudos Morfológicos com vista à sistemática dos Triatomíneos 5

1.4. Utilização da morfometria na taxonomia dos Triatominae 7

$\begin{array}{lr}\text { 1.5. Justificativa } & 10\end{array}$

2. OBJETIVOS $\quad 12$

$\begin{array}{ll}\text { 2.1. Geral } & 12\end{array}$

2.2. Específicos $\quad 12$

3. MATERIAL E MÉTODOS

3.1. Espécies selecionadas para o estudo do Processo do I Urotergito 13

$\begin{array}{ll}\text { 3.2. Descrição das técnicas } & 14 \\ 3.2 .13\end{array}$

3.2.1. Realização dos desenhos, fotografias e imagens 14

$\begin{array}{ll}\text { 3.2.2. Descrição das características morfológicas } & 15\end{array}$

3.2.3. Mensuração das estruturas morfológicas e descrição dos atributos $\quad 15$

3.3. Análise estatística das medidas morfométricas 16

$\begin{array}{ll}\text { 3.3.1. Dispersão e estabilidade das medidas } & 16\end{array}$

$\begin{array}{ll}\text { 3.3.2. Comparação das médias entre colônias } & 17\end{array}$

$\begin{array}{ll}\text { 3.3.3. Similaridade entre colônias } & 18\end{array}$

4. RESULTADOS E DISCUSSÃO 20

4.1. Aspectos gerais sobre as espécies de Triatominae estudadas 20

$\begin{array}{ll}\text { Panstrongylus megistus (Burmeister, 1835) } & 20\end{array}$

$\begin{array}{ll}\text { Rhodnius nasutus Stal, } 1859 & 21\end{array}$

Rhodnius neglectus Lent, $1954 \quad 21$

$\begin{array}{ll}\text { Rhodnius prolixus Stal, } 1859 & 22\end{array}$

\begin{tabular}{lr} 
Triatoma brasiliensis Neiva, 1911 & 22 \\
\hline
\end{tabular}

Triatoma infestans (Klug, 1834) 23

Triatoma pseudomaculata Correa \& Espínola, 1964

Triatoma rubrovaria (Blanchard, 1843) 24

\begin{tabular}{lr} 
Triatoma sordida (Stal, 1859) & 25 \\
\hline
\end{tabular}

Triatoma tibiamaculata (Pinto, 1926) 26

$\begin{array}{ll}\text { Triatoma vitticeps (Stal, 1859) } & 26\end{array}$

4.2. Estudo morfológico do Processo do I Urotergito (PIU) 27

$\begin{array}{ll}\text { 4.2.1. Descrição do Processo do I Urotergito } & 27\end{array}$

4.2.2. Características morfológicas do Processo do I Urotergito segundo $\begin{array}{ll}\text { espécies } & 29\end{array}$

$\begin{array}{ll}\text { 4.2.2.1. Gênero Panstrongylus } & 29\end{array}$

Panstrongylus megistus (Burmeister, 1835) 30

4.2.2.2. Gênero Rhodnius 31

Rhodnius nasutus Stal, $1859 \quad 32$

Rhodnius neglectus Lent, $1954 \quad 33$

Rhodnius prolixus Stal, $1859 \quad 34$

4.2.2.3. Gênero Triatoma

$\begin{array}{ll}\text { Triatoma brasiliensis Neiva, } 1911 & 37\end{array}$

$\begin{array}{ll}\text { Triatoma infestans (Klug, 1834) } & 38\end{array}$

Triatoma pseudomaculata Correa \& Espínola, 1964 
$\begin{array}{lr}\text { Triatoma rubrovaria (Blanchard, 1843) } & 40\end{array}$

Triatoma sordida (Stal, 1859) $\quad 41$

Triatoma tibiamaculata (Pinto, 1926) $\quad 42$

$\begin{array}{ll}\text { Triatoma vitticeps (Stal, 1859) } & 43\end{array}$

4.3. Estudo morfométrico do Processo do I Urotergito 47

4.3.1. Dispersão e confiabilidade das distribuições por atributo 47

4.3.2. Comparação entre colônias $\quad 55$

5. CONCLUSÕES E RECOMENDACÕES 64

6. REFERENCIAS $\quad 66$

7. ANEXOS 


\section{INTRODUÇÃO}

\subsection{Vetores da doença de Chagas}

As referências aos ancestrais dos atuais insetos vetores da doença de Chagas (DCH) datam do período Permiano (232-280 milhões de anos), época da qual foram encontrados restos fossilizados de insetos da ordem Hemiptera (SCHOFIELD 1994). LENT \& WYGODZINSKY (1979) e ZELEDON (1983) escrevem sobre os conhecimentos do Padre Reginaldo Lizarraga, quando em 1590 durante sua passagem por vários países da América do Sul (Bolívia, Chile, Argentina), relatou sobre o aspecto e hábitos dos triatomíneos e descrevia o ataque das "hitas" que correspondem certamente a $T$. infestans. SHERLOCK (1979) fez referência a Darwin na sua viagem pela América do Sul, citando que ele conhecia os triatomíneos e os chamava de "Percevejos negros sanguinários das Pampas".

Os insetos da subfamília Triatominae (Hemiptera, Reduviidae), chamados de "barbeiros" devido ao fato de picarem o rosto das pessoas enquanto dormem, são conhecidos desde o ano de 1773, quando foi descrita por De Geer, como Cimex rubrofasciatus a primeira das espécies que hoje corresponde a Triatoma rubrofasciata, espécie-tipo do gênero Triatoma (JURBERG 1999, SHERLOCK 2000).

A maioria das espécies de Triatominae habita o continente americano, entre a Latitude $42^{\circ} \mathrm{N}$ nos Estados Unidos e $43^{\circ} \mathrm{S}$ no sul da Argentina (OMS 1991, CORRÊA et al 1996). Porém, a espécie T. rubrofasciata (De Geer) habita tanto o Velho Mundo (Ásia), como o Novo Mundo, particularmente domiciliado em alguns bairros de cidades litorâneas do Brasil. Outras sete espécies de Triatoma e cinco de Linshcosteus, existem somente em países da região oriental (GORLA et al. 1997).

A importância dos triatomíneos no âmbito médico está relacionada com as perturbações que podem causar quando em grande número, tais como alteração no sono, irritações na pele e até anemia nas crianças desnutridas. As picadas causam poucas reações alérgicas, porém, existem algumas espécies norte-americanas que podem determinar até a provocação de choque anafilático dependendo da sensibilidade das pessoas picadas (MARCONDES 2001). 
Sob o ponto de vista de saúde pública, os triatomíneos são importantes devido ao papel vetorial na $\mathrm{DCH}$. $\mathrm{O}$ primeiro triatomíneo identificado como vetor da doença, o Panstrongylus megistus (Burmeister, 1835), foi achado infetado por Carlos Chagas entre 1907 e 1908 (CORRÊA \& SIQUEIRA- BATISTA 1996); até hoje, foram encontradas mais de 100 espécies natural ou artificialmente infetadas por $T$. cruzi (SHERLOCK et al. 1997, VINHÃES \& DIAS 2000).

Até o ano 2000, eram conhecidas 130 espécies de triatomíneos (SCHOFIELD 2000), sendo que dessa data em diante particularmente devido aos trabalhos de Carcavallo \& Jurberg houve um considerável incremento na descrição de novas espécies: Triatoma baratai Carcavallo \& Jurberg, 2000 (CARCAVALLO \& JURBERG 2000); Panstrongylus sherlocki Jurberg, Carcavallo \& Lent, 2001 (JURBERG et al. 2001); Rhodnius milesi Valente, Valente, Carcavallo, Rocha, Galvão\& Jurberg, 2001 (VALENTE et al. 2001); Triatoma klugi Carcavallo, Jurberg, Lent, Galvão, Steindel \& Pinto, 2001 (CARCAVALLO et al. 2001); Triatoma sherlocki Papa, Jurberg, Carcavallo, Cerqueira \& Barata 2002 (PAPA et al. 2002) e Triatoma vandae Carcavallo, Jurberg, Silva Rocha, Galvão, Noireau \& Lent, 2002 (CARCAVALLO et al. 2002). Assim, contam-se até esta data 136 espécies. Essas espécies estão agrupadas em seis tribos e dezessete gêneros (JURBERG \& GALVÃO 1997, CARCAVALLO et al. 2000, CARCAVALLO et al. 2001). As espécies mais importantes quanto à transmissão da doença de Chagas, pertencem aos gêneros Panstrongylus, Rhodnius e Triatoma, dentre as quais, são de maior risco as espécies domiciliadas (BARRETTO 1976, ZELEDON \& RABINOVICH 1981). De todos esses, o gênero Triatoma apresenta o maior número de espécies, cerca de 71 e tem a maior distribuição geográfica entre a Latitude $42^{\circ} \mathrm{N}$ nos Estados Unidos e $43^{\circ}$ $\mathrm{S}$, na região situada na Província de Chubut na Argentina (LENT \& WYGODZINSKY 1979, GORLA et al. 1997), sendo que estes limites coincidem com a área de distribuição da DCH (WHO 1991).

A DCH apareceu quando o homem invadiu áreas silvestres, transformou os habitats dos vetores e construiu moradias onde antes existiam ambientes naturais. Em áreas endêmicas, a doença está associada a fatores ambientais e sócio-políticos, tais como migração, moradia, educação podendo estar associada a outras doenças como desnutrição, diarréia, tuberculose e outras infecções parasitárias (DIAS 1987, 2001). 
Essa doença constitui ainda, um dos grandes problemas de Saúde Pública na América Latina, sendo que cerca de 100 milhões de habitantes moram ainda em regiões consideradas de risco (CDC 2002) com incidência ao redor de 16 a 18 milhões de chagásicos (WHO 1991, DIAS 1992, WORLD BANK 1993, SCHOFIELD 1994, DIAS \& SILVEIRA 1996). No Brasil, no início da década passada, estimava-se que cerca de cinco milhões de indivíduos estavam infectados e que poderia haver 20.000 casos novos ao ano no país (OMS 1991, DIAS 1992, RIBEIRO \& ROCHA 2000).

A DCH é considerada a terceira causa de óbitos dentre as doenças infecciosas e parasitárias, tendo sido registrados em torno de 6.000 óbitos por ano, na década de 1980-1990 (SILVEIRA \& REZENDE 1994).

A infecção do homem geralmente acontece devido à deposição das fezes contaminadas pelo Trypanosoma cruzi nas feridas causadas pelas picadas dos triatomíneos, por transfusão sanguínea, pela ingestão de carne crua de animais silvestres e domésticos, pelo transplante de órgãos, de forma congênita e em acidentes de laboratório e hospitais. Em alguns casos o homem pode infectar-se com as secreções das glândulas anais de gambás (MARCONDES 2001).

Diferentes pesquisadores (CARCAVALLO et al. 1985 e 1997, WENDEL et al. 1992, DIAS 2000, REY 2002) mostraram a existência de três distintos ciclos epidemiológicos da DCH, chamando-os de ciclo silvestre ou enzoótico, ciclo intermediário ou zooantroponótico e ciclo doméstico ou antroponótico, interligados por vetores e reservatórios localizados respectivamente em ecótopos silvestres, peridomiciliares ou domiciliares.

O ciclo silvestre ou enzoótico é formado por espécies de barbeiros silvestres que abrigam o T. cruzi. Esses insetos podem circular em diversos tipos de ecótopos, tais como: ninhos de pássaros e ratos (BARRETO \& CARVALHEIRO 1967 e 1968, BARRETO et al. 1967), cavernas e covas de morcegos (BARRETTO et al. 1968), tocas de canídeos como o cachorro-do-mato conhecido cientificamente como Cerdocyon thous (Linnaeus, 1766) (ALBUQUERQUE \& BARRETTO 1968), copas de palmeiras, ocos de árvores, locas de pedra, ninhos de gambá e tocas de felinos silvestres e tatus (BARRETTO et al. 1978), infectando diversas espécies de mamíferos das ordens Marsupialia (familia Didelphidae), Edentata (famílias 
Myrmecophagidae, Bradypodidae e Dasypodidae), Chiroptera (famílias Emballomeridae, Noctilionidae, Phyllostomidae, Desmodontidae, Vespertilionidae e Mollosidae), Carnívora (familias Canidae, Mustelidae e Felidae), Lagomorpha, Rodentia (famílias Sciuridae, Heteromidae, Octodontidae, Echymidae, Caviidae, Dasypodidae, Agoutidae e Brethizontidae), e Primata (famílias Cebidae e Callithricidae).

No ciclo intermediário ou zooantroponótico participam mamíferos domésticos e silvestres que por se aproximarem das moradias humanas fazem a transição desta biocenose da área silvestre para a área domiciliar, principalmente mamíferos das ordens Rodentia e Marsupialia.

Os triatomíneos que participam desse ciclo colonizam o peridomicílio e habitam particularmente os galinheiros, pombais, currais, coelheiras, chiqueiros e paióis. Tais espécies podem freqüentar também o ambiente silvestre ou domiciliário; cerca de 30 espécies já foram relacionadas nesses habitats.

Já, o ciclo domiciliar ou antroponótico passa-se no interior da casa entre seres humanos e mamíferos domesticados (cães, gatos) ou domiciliados (roedores, marsupiais, etc.). Esses reservatórios hospedam o $T$. cruzi que é transmitido por espécies de triatomíneos domiciliadas, algumas exclusivamente como o $T$. infestans (Klug, 1834) e T. rubrofasciata ou domiciliadas como o P. megistus, o T. brasiliensis Neiva, 1911, o T. pseudomaculata Correa \& Espínola, 1964, T. rubrovaria (Blanchard, 1843), T. vitticeps(Stal, 1859) etc.

\subsection{Ciclo de Infecção dos Triatominae}

Desde 1909, quando Carlos Chagas descobriu a tripanossomíase americana, observou-se que as formas sangüíneas de $T$. cruzi eram arredondadas no estômago de $P$. megistus e que essas se dividem para produzir epimastigotos compridos, no intestino delgado, que depois de 25 horas da infecção do inseto triatomíneo multiplicavam-se ativamente. Ele descreveu também os tripanossomas delgados que aparecem nas fezes do inseto e denominou aquele Trypanosoma de $T$. cruzi, em homenagem ao amigo e cientista Oswaldo Cruz (CORREA \& SIQUEIRABATISTA 1996). 
O ciclo completo do parasita no inseto foi estudado por DIAS (1934), que observou a duração do desenvolvimento de $T$. cruzi desde o momento da infecção do triatomíneo até $\mathrm{o}$ aparecimento das formas metacíclicas nas fezes. O tempo demandado entre a infecção e o aparecimento das formas tripomastigotas metacíclicas nas fezes depende entre outros fatores do estado de evolução do inseto. Assim, nas ninfas jovens, os tripomastigotas metacíclicos aparecem entre o $6^{\circ}$ e o $7^{\circ}$ dia, enquanto que nas ninfas mais maduras e nos adultos, podem aparecer nas fezes do inseto entre 10 e 15 dias após a infecção.

Embora todas as espécies de triatomíneos sejam potencialmente vetoras de $T$. cruzi, é necessário que seja conhecida a epidemiologia da transmissão de cada área para que seja determinado o papel significativo de cada espécie triatomínea vetora. Tal estudo começa naturalmente pelo conhecimento empírico dos índices de infecção por $T$. cruzi de cada espécie triatomínea conhecido como competência vetorial ou pelos índices de infestação de cada área endêmica onde é estudada a densidade, uma das características da capacidade vetorial. Estes são determinados de modo global, por ecótopos como o intradomicílio, peridomicílio e extradomicílio, por procedência como localidades, municípios, estados ou por estádios como adulto macho, fềmea e ninfa (SHERLOCK 2000).

\subsection{Estudos Morfológicos com vista à sistemática dos Triatomíneos}

Os insetos da subfamilia Triatominae apresentam inúmeros caracteres morfológicos usados na sua identificação que, em geral, são de fácil distinção, permitindo na maior parte dos exemplares determinação específica. Entretanto, para algumas espécies, esses caracteres são muito semelhantes, dificultando uma identificação adequada.

Nas pesquisas sobre taxonomia de triatomíneos, têm sido realizados estudos morfológicos nas fases de ovos, ninfas e adultos.

Os caracteres morfológicos dos ovos como auxiliares na identificação dos hemípteros da subfamília Triatominae, tais como o estudo do exocório, tem sido usado por diversos autores (BARATA et al. 1980, BARATA et al. 1981, BARATA et al. 1993, BARATA et al. 1994b, BARATA 1995, COSTA et al. 1991, JURBERG 
et al. 1993, JURBERG \& CAMPOS 1995, ROSA et al. 2000b, SILVA et al. 2000, JURBERG et al. 2002).

Em relação às pesquisas sobre ninfas, ESPÍNOLA (1966) estudou as diferenças quanto ao dimorfismo sexual de ninfas de $5^{\circ}$ estádio de 11 espécies de triatomíneos; PERLOWAGORA-SZUMLEWICZ \& CRUZ (1972) estudaram o dimorfismo sexual de ninfas de $3^{\circ}$ estádio de quatro espécies do gênero Triatoma; ROSA et al. (1992a) e SANTOS et al. (1999) realizaram estudos sobre as diferenças quanto ao dimorfismo sexual de ninfas de $5^{\circ}$ estádio; ROSA et al. (1992b) trabalharam em observações de espiráculos das ninfas de $5^{\circ}$ estádio. A estrutura do $8^{\circ}$ e $9^{\circ}$ urosternito de ninfas fêmeas de $5^{\circ}$ estádio foi estudada por ROSA et al. (1997); ROSA et al. (1999) estudaram a estrutura da cabeça do $1^{\circ}$ e $5^{\circ}$ estádio das ninfas; SILVA et al. (1999) trabalharam com placas apicais do lábio das ninfas de $1^{\circ}$ estádio; ROSA et al. (2000b) analisaram a morfometria dos segmentos antenais de ninfas e adultos.

Em relação aos adultos, como em todos os insetos a morfologia foi sempre muito utilizada; uma das estruturas usadas há longo tempo foi o padrão da relação da implantação dos tubérculos anteníferos na cabeça para diferenciar os gêneros Panstrongylus, Rhodnius e Triatoma (PINTO 1930); as estruturas fálicas para diferenciar machos de triatomíneos, foram particularmente incorporadas a partir de 1969 (LENT \& JURBERG 1969), enquanto que os aspectos morfológicos, de cor e distribuição geográfica foram incluídos posteriormente (LENT \& WYGODZINSKY 1979); a morfologia dos tubos testiculares foi utilizada por SCHREIBER et al. (1968) e por GONÇALVES et al. (1987); o uso de estruturas cuticulares, por CARCAVALLO et al. (1994); ápice do processo do escutelo, por CARCAVALLO \& GIRÓN (1995), a morfologia das cerdas abdominais, por ROSA et al. (1989 e 1995); a distribuição das sensilas nos segmentos abdominais, por GORLA et al. (1993), CATALÁ \& SCHOFIELD (1994), CATALÁ (1996 e 1997) e morfometria da cabeça e das asas (DUJARDIN et al. 1997a e 1997b, CAHET et al. 1999, MATIAS et al. 2001).

Mais recentemente os usos da genética e da biologia molecular têm ganhado muita importância na separação das espécies e populações desses insetos que apresentam características de comportamento e distribuição geográfica diferentes 
(HARRY et al. 1992, HARRY 1993, SOLANO et al. 1996, DUJARDIN et al. 1997c e 1999c, CHAVEZ et al. 1999; SOARES et al. 1999, NOIREAU et al. 2000). Mais recentemente, a utilização do Processo do I Urotergito, motivo da sistematização do presente trabalho, tem mostrado grande utilidade (BARATA et al. 1994a, 1996a, 1996b, 1996c, 1998a, 1998b, 1999a, 1999b).

O Processo do I Urotergito situa-se na região dorsal, na divisa entre o tórax e o abdome, logo abaixo do escutelo e das asas. A estrutura tem mostrado, em estudos preliminares, excelentes resultados na diferenciação de alguns gêneros e de várias espécies de triatomíneos (BARATA et al. 1994a). Entretanto, a proposta deste trabalho foi aprofundar o estudo da utilização dessa estrutura, particularmente no que concerne às comparações morfométricas entre as diferentes espécies, com ênfase nas brasileiras.

A determinação e a sistematização mais precisa dessas estruturas, em muito contribuirá para facilitar a identificação de espécies, principalmente aquelas de difícil separação taxonômica. Para isso, contar-se-á com a participação de recursos ópticos avançados como o microscópio eletrônico de varredura e o equipamento para processamento digital de imagens pelo software Leica Qwin.

\subsection{Utilização da morfometria na taxonomia dos Triatominae}

A palavra morfometria foi cunhada por Blackith em 1965 para designar métodos usados na mensuração da "distância de forma" entre espécies, e a partir daí, construir fenogramas levando em consideração as características ecológicas ou filogenéticas de cada grupo (MONTEIRO \& REIS 1999).

Pode ser subdividida em morfometria tradicional e geométrica, sendo que na primeira, as variáveis são calculadas por distâncias entre pontos homólogos que posteriormente são analisados por métodos estatísticos univariados e multivariados. Na segunda modalidade, os pontos de referência são transformados em coordenadas que logo viram distâncias que posteriormente são tratadas estatisticamente.

As aplicações da morfometria nos estudos de insetos geralmente são orientadas para os seguintes aspectos: estudos morfométricos para justificar sinonímias, detecção de diferenças entre populações muito próximas e 
reconhecimento de novos taxa em nível de espécie (CARCAVALLO et al. 1997, DALY 1985).

A morfometria, como mais uma ferramenta para o esclarecimento da taxonomia dos triatomíneos, tem sido usada há vários anos, por diferentes pesquisadores, para as análises sistemáticas e filogenéticas.

BARATA et al. (1980, 1981) estudaram aspectos morfológicos e morfométricos dos ovos de 10 espécies do gênero Rhodnius Stal, 1856. Como resultado dessa pesquisa foi possível elaborar chaves dicotômicas para a classificação dessas espécies, baseadas na utilização dos caracteres visíveis pela Microscopia Óptica (MO) e Microscopia Eletrônica de Varredura (MEV).

MASCARENHAS (1982) realizou mensurações no comprimento e na largura de exemplares adultos de Rhodnius brethesi Matta, 1919, comparando-as com as realizadas por BARATA et al. (1981) para outras 10 espécies de Rhodnius. O valor médio obtido para o comprimento e a largura do ovo foi de $1,668 \mathrm{~mm}$ e $0,785 \mathrm{~mm}$ respectivamente.

JURBERG \& CAMPOS (1995) trabalharam detalhadamente o exocório de ovos e a morfologia, morfometria e anatomia dos folículos testiculares das ninfas do $5^{\circ}$ estádio de Triatoma vitticeps. Através do MO, eles conseguiram ampliar os parâmetros para identificação dos estádios imaturos dessa espécie.

GORLA et al. (1993) realizaram análise morfométrica de dezessete variáveis, para diferenciar algumas espécies do complexo Triatoma sordida (Stal, 1859), usando análise multivariada. Estatísticas descritivas das três espécies mostraram que compartilham o mesmo leque de valores dos parâmetros calculados.

GALINDEZ-GIRON et al. (1994) aplicaram técnicas de análise multivariada para comparar 19 caracteres morfológicos em 6 colônias de $R$. prolixus Stal, 1859 e $R$ robustus Larrousse, 1927 , a partir de mensurações morfométricas. $O$ resultado revelou que os três tipos de testes estatísticos permitem diferenciar as características morfométricas das seis amostras analisadas.

HARRY (1994) comparou seis populações domésticas de $R$. prolixus, uma silvestre de $R$. robustus, uma de $R$. pictipes Stal, 1872 da Venezuela, uma de $R$. nasutus Stal, 1859 e uma de $R$. neglectus Lent, 1954 do Brasil; por meio da análise morfométrica de 16 caracteres morfológicos observou que espécimes domésticos 
apresentaram dimensões menores que aqueles coletados no ambiente silvestre. Em relação à variabilidade morfológica interespecífica, observou marcada diferenciação de $R$. pictipes das outras espécies. $R$. nasutus e $R$. neglectus mostraram clara diferenciação morfológica uma da outra; GALINDEZ-GIRON et al. (1997) visando a conhecer as variações morfométricas fenotípicas de $R$. robustus da Venezuela, utilizaram Análises de Componentes Principais (ACP) e análise discriminante, sobre um total de 22 variáveis quantitativas e detectaram diferenças significativas entre machos e fềmeas da mesma localidade e de localidades diferentes.

GORLA et al. (1997) estudaram espécies de gênero Linchcosteus e Triatoma e conseguiram mostrar diferenças entre eles por meio da análise morfométrica; DUJARDÍN et al. (1997a) usaram sete medidas da cabeça para comparar ninfas de $T$. infestans de $5^{\circ}$ estádio, um primeiro grupo coletado antes do tratamento químico das casas, um segundo originado na população silvestre e um terceiro das ninfas que reinfestaram as casas a partir da população silvestre ou que sobreviveram à aplicação do produto químico, com o intuito de estabelecer diferenças entre populações de triatomíneos submetidos a controle químico em diferentes épocas.

As diferenças morfométricas entre as ninfas da população reinfestante e as ninfas da população silvestre, como as semelhanças entre as ninfas reinfestantes e as ninfas domésticas, fazem sustentar a hipótese de uma população doméstica residual que sobreviveu à aplicação do inseticida. DUJARDÍN et al. (1997b) usaram análise canônica para diferenciar populações silvestres e domésticas de $T$. infestans através do estudo morfométrico da cabeça e das asas. As diferenças morfológicas observadas entre as populações silvestres e domésticas são interpretadas como uma possível incipiente reagrupação entre elas. DUJARDÍN et al. (1998) usaram diferenças morfométricas para monitorar populações de P. rufotuberculatus (Champion, 1899) em processo de domiciliação na Bolívia. Um total de nove medidas da cabeça dos adultos machos foram utilizadas para demonstrar redução de tamanho dos espécimes domiciliados em relação aos espécimes silvestres. DUJARDíN et al. (1999b) demonstraram através da análise morfométrica que alterações no dimorfismo sexual de Rhodnius e Triatoma podem ser usadas como indicadores de espécies em fase de transição de habitats silvestres para habitats artificiais. Esse fato permite incluir as 
análises morfométricas para monitorar populações sob o ponto de vista de vigilância epidemiológica em programas de controle da doença de Chagas.

ROSA et al. (2000b) estudaram a morfologia dos ovos de T. circummaculata Stal, 1859 e T. rubrovaria através de Microscopia Eletrônica de Varredura (MEV) e a morfometria usando Projetor de perfil. Os resultados mostraram que as espécies apresentam tamanhos e caracteres morfológicos distintos, sendo os ovos e cascas de T. rubrovaria significativamente maiores que os de $T$. circummaculata.

ROSA et al. (2000a) estudaram morfometricamente os segmentos antenais de ninfas e adultos de duas colônias de $T$. rubrovaria. Os resultados e respectivas análises estatísticas mostraram que os comprimentos de cada um dos quatro segmentos antenais diferem nos estádios evolutivos da seguinte forma: $1^{\circ}$ e $2^{\circ}$ estádios ninfais $\mathrm{IV}^{\circ}>\mathrm{III}^{\circ}>\mathrm{II}^{\circ}>\mathrm{I}^{\circ} ; 3^{\circ}$ estádio, III $>\mathrm{IV}>\mathrm{II}>\mathrm{I} ; 4^{\circ}$ estádio ninfas fềmea e macho do $5^{\circ}$ estádio e fềmea e macho adultos II $>$ III $>I V>I$.

SILVA et al. (2000) realizaram estudos morfológico e morfométrico de ovos e ninfas de Triatoma guazu Lent \& Wygodzinsky, 1979 utilizando MO e MEV. Para a descrição desses estados foram incluídos três caracteres dos ovos e doze caracteres da cabeça dos cinco estádios ninfais.

MATIAS et al. (2001) utilizaram medidas morfométricas das asas para comparar populações de $R$. stali Lent, Jurberg \& Galvão, 1993, $R$. robustus, $R$. pictipes e $R$. prolixus; os resultados mostraram claras diferenças entre $R$. robustus, $R$. stali e $R$. pictipes e poucas diferenças com $R$. prolixus. Essa análise confirmara a presença de $R$. robustus na Bolívia.

PATTERSON et al. (2001) demonstraram alto grau de similaridade entre $T$. rubrofasciata e espécies triatomíneas do Velho Mundo, por meio da análise multivariada de dados morfométricos.

\subsection{Justificativa}

O estudo do Processo do I Urotergito em adultos de triatomíneos, por meio de Microscopia Óptica (MO), Microscopia Digital (MD) e Microscopia Eletrônica de Varredura (MEV), contribuirá para a identificação taxonômica mais precisa dos Triatominae. Essa estrutura, embora seja perceptível por MO, mostra detalhes morfológicos tais como cerdas, estrias ou outros tipos de ornamentações, que 
somente são visualizados por $\mathrm{MD}$ e ou por $\mathrm{MEV}$, daí a importância da utilização dessas duas técnicas.

O uso desses equipamentos permitiu a ampliação da visualização de estruturas até então pouco utilizadas na taxonomia.

Por outro lado, a mensuração e a análise morfométricas dos diversos atributos e estruturas morfológicas, utilizando as imagens digitais obtidas, forneceu parâmetros precisos para a efetiva caracterização do PIU, considerando que a morfometria tem-se mostrado nos últimos anos com uma ferramenta taxonômica adicional que associada aos parâmetros fálicos, isoenzimáticos, morfológicos e ecológicos contribuirá no futuro para o esclarecimento da sistemática e filogenia das espécies de triatomíneos. 


\section{OBJETIVOS}

\subsection{Geral}

Avaliar o valor taxonômico de uma estrutura morfológica dos Triatominae, ainda pouco conhecida, e propor seu uso na caracterização de espécies, particularmente, àquelas de difícil distinção.

\subsection{Específicos}

I. Avaliar o valor taxonômico da estrutura denominada "Processo do I Urotergito" para a utilização na identificação de espécies de Triatominae.

II. Mostrar a eficiência da Microscopia Eletrônica de Varredura, Microscopia Óptica e Microscopia digital, na descrição das características morfológicas do Processo do I Urotergito.

III. Analisar morfometricamente o valor taxonômico das áreas do Processo do I Urotergito nas espécies de triatomíneos estudadas, utilizando a Microscopia Digital.

IV. Obter informações baseadas no estudo do Processo do I Urotergito, de modo a contribuir ao esclarecimento da taxonomia dos triatomíneos. 


\section{MATERIAL E MÉTODOS}

\subsection{Espécies selecionadas para o estudo do Processo do I Urotergito}

Foram usados insetos machos de onze espécies de triatomíneos provenientes do Insetário do Serviço Especial de Saúde de Araraquara (SESA), pertencente à Faculdade de Saúde Pública da USP. Foi dada prioridade às espécies com importância na transmissão de $T$. cruzi e com disponibilidade de material naquele insetário. Cada uma das espécies ou colônia de espécie, porém tem procedência diferenciada, e foi identificada com um código alfanumérico CTA (Colônia Triatomíneos de Araraquara) e um número de ordem.

Selecionaram-se as seguintes espécies para o estudo: Panstrongylus megistus (Burmeister, 1835), Rhodnius nasutus Stal, 1859, Rhodnius neglectus Lent, 1954, Rhodnius prolixus Stal, 1859, Triatoma brasiliensis Neiva, 1911, Triatoma infestans (Klug, 1834), Triatoma pseudomaculata Correa \& Espínola, 1964, Triatoma rubrovaria (Blanchard, 1843), Triatoma sordida (Stal, 1859), Triatoma tibiamaculata (Pinto, 1926) e Triatoma vitticeps (Stal, 1859). Para cada uma dessas espécies, foi preparada uma amostra composta por cinco exemplares de cada procedência.

Assim, foram estudadas: P. megistus CTA 145 Município de Almino AfonsoRN e CTA 151 Curitiba- PR; $R$. nasutus CTA 060 Município de Patú -RN; $R$. neglectus CTA 001 Município da Guaíra- São Paulo; $R$. prolixus CTA 034 da Colômbia; T. brasiliensis CTA 076 Município de São João- Piauí, Triatoma infestans CTA 007 Município de Mambai- GO, T. pseudomaculata CTA 111 Município de Messias Targino- RN; $T$. sordida CTA 026 Município de Tanhaçu- BA; $T$. rubrovaria CTA 117 Município de Pelotas- RS; T. tibiamaculata CTA 157 Município de Mogi Guaçu- SP e T. vitticeps CTA 006 Município de Guaraparí- ES. 


\subsection{Descrição das técnicas}

\subsubsection{Realização dos desenhos, fotografias e imagens}

Para a realização dos desenhos, fotografias e imagens do Processo do I Urotergito das espécies selecionadas, foi obedecido o seguinte procedimento:

Cinco exemplares de cada procedência foram sacrificados em tubo mortífero com clorofórmio; uma vez mortos, foram retiradas as asas anteriores e posteriores dos insetos por meio de pinças entomológicas de ponta fina; após isso, foram separados sob lupa estereomicroscópica com iluminação artificial, os Processos do I Urotergito de cada um dos exemplares, utilizando tesoura e pinças entomológicas.

Com o objetivo de eliminar tanto as impurezas como restos de tecidos, foi realizada a limpeza das peças. Para tal, as estruturas foram colocadas em pequenas placas de Petri, contendo acetona e levadas ao aparelho de ultra-som por meia hora.

Posteriormente, as peças foram submetidas a secagem em estufa a $40^{\circ} \mathrm{C}$, por 24 horas.

Já secos, os urotergitos foram levados à lupa estereoscópica Zeis® Stemi SV6 acoplada à câmara clara para realizar os desenhos das peças.

As mesmas peças foram posteriormente fotografadas por meio de câmara fotográfica marca Zeiss ${ }^{\circledR}$ acoplada ao microscópio estereoscópico Zeiss® Stemi SV6, utilizando como referência para as medidas uma régua com escala em milímetros.

A captura de imagens digitais foi realizada em um equipamento composto de câmera digital JVC® modelo TK-C 1380U acoplada ao microscópio estereoscópico Leica ${ }^{\circledR}$ MZAPO e a um computador provido de software para análise de imagens. Posteriormente, as imagens gravadas foram utilizadas para realizar a morfometria digital e impressas para posterior análise morfológica.

Para a realização das fotografias em $\mathrm{MEV}$, as peças do Processo do I Urotergito foram fixadas em pequenos toros de latão e/ou alumínio $\mathrm{com} 1.0 \mathrm{~cm}$ 
de diâmetro por $0,5 \mathrm{~cm}$ de altura através de esmalte de unhas (incolor). Posteriormente as peças foram revestidas primeiramente pelo carbono e depois pelo ouro em metalizador a vácuo JEE-SS-JEOL®.

As fotografias no MEV foram realizadas com câmera fotográfica acoplada ao microscópio marca JEOL® JSMT-330A, utilizando aumentos de $35 \mathrm{X}$ ou 50X, de acordo com o tamanho da peça.

Por fim, foi realizada a revelação das fotografias, sendo selecionadas as melhores para as análises sob o ponto de vista morfológico.

\subsubsection{Descrição das características morfológicas}

As características morfológicas mais evidentes do Processo do I Urotergito de cinco exemplares de cada amostra das espécies de triatomíneos selecionadas, foram descritas e comparadas qualitativamente, utilizando os desenhos realizados com câmera clara, as imagens digitais e as fotografias obtidas no $\mathrm{MEV}$.

\subsubsection{Mensuração das estruturas morfológicas e descrição dos atributos}

As imagens do Processo do I Urotergito de cinco exemplares de cada uma das colônias de triatomíneos, foram mensuradas em milímetros, utilizando analisador de imagem (QWin Image Analysis System ${ }^{\circledR}$ ) dotado de programa de computador Leica Q win®.

Os seis atributos do Processo do I Urotergito medidos foram: Largura Basal do $1^{\circ}$ Urotergito (LBU1), determinada como a distância entre os pontos extremos da base do urotergito 1; Largura Basal do $2^{\circ}$ Urotergito (LBU2), determinada como a distância entre os pontos extremos da base maior do trapézio formado pelo urotergito 2 ; Largura Maior da Área Circular (LMAC), determinada como a distância entre as duas estrias centrais dessa área, no ponto de maior separação delas; Largura Apical do $2^{\circ}$ Urotergito (LAU2), determinada como a linha reta que une os extremos apicais das linhas oblíquas que formam a base menor do trapézio formado pelo urotergito 2 ; Comprimento do $1^{\circ}$ Urotergito (CU1) no nível da linha média, determinado como a distância entre o ponto médio da base do urotergito 1 e o vértice do triângulo formado e Comprimento do $2^{\circ}$ Urotergito (CU2) no nível da linha média, 
determinado como a distância entre o ponto médio da base do urotergito 2 e o ponto médio da linha apical do mesmo (Fig. 1).

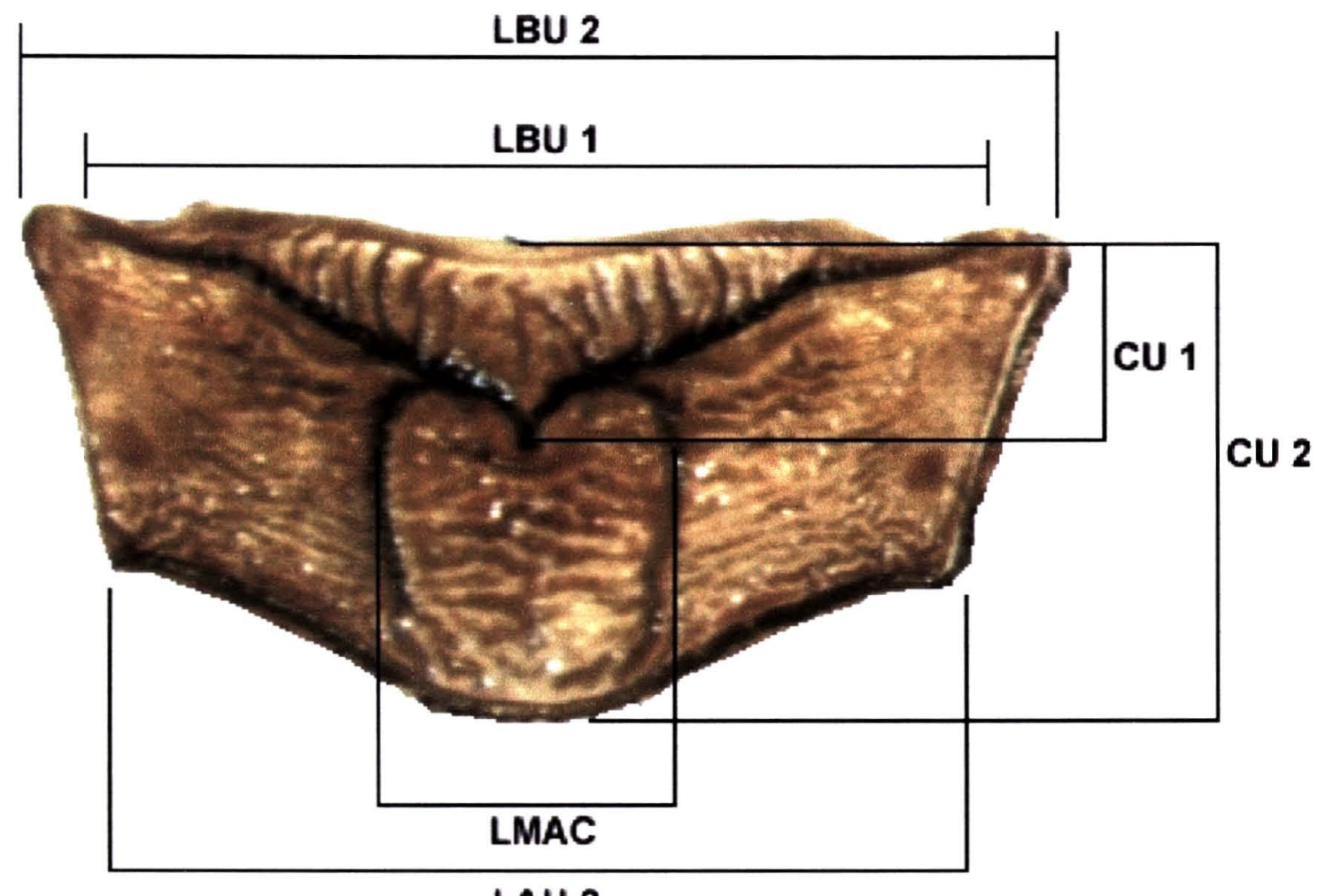

Figura 1- Vista dorsal do Processo do I Urotergito de Triatoma tibiamaculata (Pinto, 1926) com as mensurações morfométricas: LBU1- Largura Basal do $1^{\circ}$ Urotergito; LBU2- Largura Basal do $2^{\circ}$ Urotergito; LMAC- Largura Maior da Área Circular; LAU2- Largura Apical do $2^{\circ}$ Urotergito; CU1- Comprimento do $1^{\circ}$ Urotergito; CU2Comprimento do $2^{\circ}$ Urotergito.

\subsection{Análise estatística das medidas morfométricas}

\subsubsection{Dispersão e estabilidade das medidas}

O estudo descritivo das medidas morfométricas foi realizado pelo cálculo da média, desvio padrão e coeficiente de variação para os seis atributos, segundo cada uma das espécies analisadas. O Coeficiente de Variação (CV) foi calculado pela expressão: 


$$
\mathrm{CV}=\frac{\sqrt{\sum_{i=1}^{5}\left(x_{i}-x\right)^{2} / n-1}}{x} \text {, sendo o i-ésimos valor de x corresponde à }
$$

cada medida observada. Os termos dessa razão (desvio padrão e média) foram obtidos por processamento do comando MEANS no software Epi Info versão 6.04B (DEAN et al. 1994).

Ainda para cada espécie, foram calculados os Coeficientes de Correlação de Pearson (BERQUÓ et al. 1981) por

$$
(\mathrm{r})=\frac{\sum_{i=1}^{5}\left(x_{i}-\bar{x}\right)\left(y_{i}-\bar{y}\right)}{\sqrt{\sum_{i=1}^{5}\left(x_{i}-\bar{x}\right)^{2} \cdot \sum_{i=1}^{5}\left(y_{i}-\bar{y}\right)^{2}}} \text {, sendo os i-ésimos pares de desvios em }
$$

relação às respectivas médias $\left(x_{i}-\bar{x}\right),,\left(y_{i}-\bar{y}\right)$ correspondem às mensurações registradas para cada dois atributos. Os resultados, obtidos por processamento no Excel, foram apresentados mediante matrizes de correlação referentes às 12 colônias.

\subsubsection{Comparação das médias entre colônias}

Possiveis diferenças para um mesmo atributo foram avaliadas pela comparação simultânea das doze médias verdadeiras referidas para o conjunto das espécies estudadas. Os resultados obtidos para as análises de variância foram processados pelo uso do comando MEANS do software Epi-Info 6.04, e apresentamse em seis tabelas, conforme modelo abaixo, contendo valores para a estatística $F$ (COSTA NETO 1977) e o valor-p, cujos resultados inferiores a 0,05 indicaram a existência de diferenças significantes para o mesmo atributo entre as colônias estudadas. 
Quadro 1- Termos para calculo da estatística F sob o modelo ANOVA para amostras de tamanhos iguais $(n=5)$.

\begin{tabular}{|c|c|c|c|c|c|}
\hline Variação & $\begin{array}{l}\text { Graus de } \\
\text { Liberdade }\end{array}$ & $\begin{array}{l}\text { Soma de } \\
\text { Quadrados }\end{array}$ & $\begin{array}{l}\text { Quadrado } \\
\text { Médio }\end{array}$ & $\mathrm{F}$ & Valor-p \\
\hline $\begin{array}{l}\text { Entre } \\
\text { espécies }\end{array}$ & 11 & $\begin{array}{l}\mathrm{SQT}= \\
5 . \sum_{i=1}^{12}\left(\bar{y}_{i .}-\bar{y}\right)^{2}\end{array}$ & $\mathrm{QMT}=\mathrm{SQT} / 11$ & & \\
\hline Resíduo & 48 & $\begin{array}{l}\mathrm{SQR}= \\
\sum_{i=1}^{12} \sum_{j=1}^{5}\left(y_{i j}-y_{j}\right)^{2}-\end{array}$ & $\mathrm{QMR}=\mathrm{SQR} / 48$ & QMT/QMR & \\
\hline Total & 59 & $\begin{array}{l}\mathrm{SQT}= \\
\sum_{i=1}^{12} \sum_{j=1}^{5}\left(y_{i j}-\bar{y}\right)^{2}\end{array}$ & & & \\
\hline
\end{tabular}

A normalidade para a distribuição das medidas observadas em cada amostra é a pressuposição básica para a realização do processamento. Nos atributos em que se registrou ausência significante de homogeneidade entre as variâncias das doze amostras, a estatística $\mathrm{F}$ foi substituída pelo teste não paramétrico de Kruskal-Wallis (SIEGEL 1956), também calculado pelo Epi Info 6.04B.

\subsubsection{Similaridade entre colônias}

Gráficos de dispersão das 12 colônias permitiram visualizar a possível existência de agrupamentos de algumas delas para os seis atributos avaliados. A similaridade entre as espécies foi, então, avaliada pela técnica multivariada de análise de agrupamentos, com aplicação do método aglomerativo hierárquico, denominado “average link" (ALDENDERFER \& BLASHFIELD 1986). A análise multivariada diferentemente da univariada, tem a vantagem de combinar as variáveis iniciais, 
transformando-as em fatores, ou seja, condensam de forma sucinta uma grande massa de dados (JAMES \& McCULLOCH 1990).

O processamento efetuado pelo software S- PLUS 2000 (MATHSOFT 2000) teve como entrada a matriz exposta na Tabela 1, em que cada linha refere-se a uma colônia como o objeto a ser agrupado.

Tabela 1- Médias estimadas para seis atributos taxonômicos nas colônias Panstrongylus megistus 145 (PM145), P. megistus 151 (PM151), Rhodnius nasutus (RNA), $R$. neglectus (RNE), R. prolixus (RPRO), Triatoma brasiliensis (TBRAS), $T$. infestans (TINF), T. pseudomaculata (TPSDM), T. rubrovaria (TRUB), T. sordida (TSOR), T. tibiamaculata (TTIB) e T. vitticeps (TVIT).

\begin{tabular}{lllllllll}
\hline \multirow{2}{*}{ colônias } & \multicolumn{7}{l}{ Atributos Taxonômicos } \\
\cline { 3 - 5 } & LBU1 & LBU2 & LMAC & LAU2 & CU1 & CU2 \\
\hline PM145 & 6,92 & 7,75 & 2,19 & 6,33 & 1,67 & 3,54 \\
PM151 & 6,74 & 7,35 & 2,15 & 6,02 & 1,55 & 3,15 \\
RNA & 3,29 & 4,04 & 0,32 & 3,80 & 0,87 & 1,92 \\
RNE & 4,05 & 4,84 & 0,43 & 4,73 & 1,05 & 2,25 \\
RPRO & 3,85 & 4,69 & 0,42 & 4,56 & 1,05 & 2,18 \\
TBRA & 2,97 & 3,74 & 0,99 & 3,38 & 0,97 & 1,72 \\
TINF & 4,47 & 5,20 & 1,68 & 4,41 & 1,10 & 2,35 \\
TPSDM & 3,20 & 3,99 & 1,39 & 3,21 & 1,04 & 1,89 \\
TRUB & 3,25 & 3,26 & 1,20 & 2,83 & 0,73 & 1,44 \\
TSOR & 3,85 & 3,85 & 1,37 & 3,09 & 0,92 & 1,68 \\
TTIB & 6,59 & 7,30 & 2,22 & 6,04 & 1,51 & 3,46 \\
TVIT & 7,48 & 8,14 & 3,01 & 7,04 & 2,03 & 3,97 \\
\hline
\end{tabular}

LBU1: Largura Basal do $1^{0}$ Urotergito, LBU2: Largura Basal do $2^{0}$ Urotergito, LMAC: Largura Maior da Área Circular, LAU2: Largura Apical do $2^{\circ}$ Urotergito, CU1: Comprimento do $1{ }^{\circ}$ Urotergito, CU2: Comprimento do $2^{0}$ Urotergito.

Os resultados apresentados por um diagrama de árvore, intitulado dendrograma, permitiram identificar os principais agrupamentos das espécies consideradas similares, segundo classificação efetuada de acordo com as distâncias calculadas entre as médias dos atributos taxonômicos pesquisados (BUSSAB et al. 1990). 


\section{RESULTADOS E DISCUSSÃO}

A apresentação dos resultados e a discussão foram divididas em três subcapítulos: aspectos gerais sobre as espécies triatomíneas estudadas, estudo morfológico do Processo do I Urotergito (PIU) e estudo morfométrico do Processo do I Urotergito. No primeiro, foram colocados alguns aspectos gerais sobre taxonomia, ecologia e epidemiologia associados a cada uma das espécies, com base na literatura revisada. No segundo foi inicialmente feita a descrição da localização e da estrutura do PIU; depois são apresentadas as características do gênero e finalmente é apresentada a discussão dessa estrutura para cada gênero e espécie.

No terceiro subcapítulo foram discutidas as relações interespecificas, visando a mostrar as variações dos seis atributos taxonômicos nas 12 colônias de triatomíneos.

\subsection{Aspectos gerais sobre as espécies de Triatominae estudadas}

\section{Panstrongylus megistus (Burmeister, 1835)}

Apesar de ter sido descrita utilizando exemplares coletados no Brasil, a localidade tipo não foi especificada por Burmeister, quando da publicação em 1835. Devido a sua ampla distribuição geográfica no país e a sua elevada susceptibilidade ao T. cruzi é considerado o vetor mais importante da doença de Chagas (SHERLOCK 2000).

Foi a primeira espécie implicada por Carlos Chagas na transmissão de $T$. cruzi (CORRÊA \& SIQUEIRA-BATISTA 1996). Em áreas úmidas do litoral brasileiro, especialmente no Estado da Bahia, $P$. megistus é o mais importante vetor de T. cruzi (SCHOFIELD et al. 1987) e sua distribuição abrange a área compreendida desde o Estado do Rio Grande do Sul ao Pará (REY 2002).

$O$ centro de endemismo dessa espécie, segundo FORATTINI (1980), é o ecossistema Atlântico que se estende do Norte do Rio Grande do Sul ao Nordeste brasileiro. Nessa área, coabitam populações de $P$. megistus que apresentam maior ou menor capacidade de domiciliação. Especificamente as populações distribuídas em regiões submetidas a maior alteração ambiental apresentaram maior capacidade de domiciliação. Ao contrário das anteriores, as populações localizadas abaixo da linha 
de clima mesotérmico, onde a mata primária ainda se preserva, são populações exclusivamente silvestres, embora em algumas ocasiões possam aparecer adultos invadindo residências próximas às matas (FORATTINI et al. 1970, 1978, FORATTINI 1980).

Nas áreas em que as populações de $P$. megistus são domiciliadas, os insetos podem ser encontrados tanto em domicílios quanto em anexos ou em ecótopos silvestres particularmente nas áreas limítrofes dessas regiões. Contudo na Região Nordeste do país os exemplares têm sido mais encontrados nos domicílios e na área litorânea da Região Sudeste, tem como habitat silvestre preferencial os ninhos de marsupiais (SHERLOCK 2000).

\section{Rhodnius nasutus Stal, 1859}

A localidade onde o exemplar usado como tipo foi coletado é dada por Stal, como "Siará" em 1859. É provável que corresponda ao Estado do Ceará, Brasil, porque é juntamente com o Estado do Rio Grande do Norte onde é mais encontrado; inclusive tem sido verificada a existência de colônias intradomiciliares (SILVEIRA \& REZENDE 1994). O tipo está depositado na Coleção Entomológica do Instituto Oswaldo Cruz, Rio de Janeiro.

Essa espécie tem sido encontrada ocasionalmente em casas, galinheiros e currais. É comum no Nordeste brasileiro, distribuindo-se nos Estados do Ceará, Piauí, e Rio Grande do Norte (LENT \& WIGODZINSKY 1979). Nos Estados do Ceará e Rio Grande do Norte, tem sido observada a presença de colônias intradomiciliares (SILVEIRA \& REZENDE 1994); ainda assim as taxas de infecção natural por $T$. cruzi nessa espécie são baixas.

\section{Rhodnius neglectus Lent, 1954}

O exemplar tipo foi coletado na Fazenda Águas Limpas, Município de Uberaba, Minas Gerais, Brasil, por Lent, em 1954. O tipo está depositado na Coleção Entomológica do Instituto Oswaldo Cruz, Rio de Janeiro.

É considerado vetor secundário da doença de Chagas no Brasil. Sua extensa distribuição abrange as Regiões Sul, Sudeste e Centro- Oeste do País, onde tem sido encontrado nos Estados do Paraná, Minas Gerais, Mato Grosso do Sul, Mato Grosso, 
Sergipe, Piauí, Pernambuco, Bahia, Maranhão e Rondônia. Nesses estados é freqüentemente encontrado no peridomicílio das casas (SILVEIRA 1984).

No Estado de Goiás, essa espécie tem sido mais freqüentemente encontrada naturalmente infectada por T. cruzi e, algumas vezes colonizando moradias humanas, provavelmente como resultado da ocupação de espaços abertos após o controle do $T$. infestans (DIOTAIUTI \& DIAS 1984, SILVEIRA et al. 1983, SILVEIRA \& REZENDE 1994, SOARES et al. 1999, SILVEIRA 2000).

\section{Rhodnius prolixus Stal, 1859}

La Guaira, Venezuela, é a localidade típica dessa espécie. Foi descrita por Stal, em 1859. O Tipo foi depositado no Museu de Berlim, Alemanha.

É o principal vetor da doença de Chagas na Venezuela, Colômbia e alguns países de América Central (MONTEIRO et al. 2000, JARAMILLO et al. 2001) e tem sido encontrado também no Brasil (BARATA et al. 1996a). É provável que, como dito por SCHOFIELD et al. (1987), tais achados na região Central e Sul do Brasil, sejam devido à confusão taxonômica com $R$. neglectus.

Essa espécie é a mais importante epidemiologicamente, devido à ampla valência ecológica e distribuição geográfica, altas densidades, boa adaptação aos domicílios e eficiência como vetor da doença de Chagas (ZELEDON \& RAVINOVICH 1981).

\section{Triatoma brasiliensis Neiva, 1911}

O exemplar considerado tipo foi coletado na localidade de Caicó, Rio Grande do Norte, Brasil, por Neiva, em 1911; está depositado na Coleção Entomológica do Instituto Oswaldo Cruz, Rio de Janeiro.

No Nordeste é chamado de "bicudo" e de "bicho de parede preto".

É uma espécie que prevalece nos habitats peridomiciliares, tais como galinheiros e currais para cabras. No ambiente silvestre predomina nos montões de rochas associados com ninhos de grandes roedores de porte avantajado denominados vulgarmente de "mocós" e "preás"e cientificamente, conhecidos como Kerodon rupestris (Wied, 1820) e Cavia aperea Erxsleben, 1777 os quais em algumas áreas dessa região são usados como alimento. 
Essa espécie é encontrada nos domicílios, peridomicílios e no ambiente silvestre (SHERLOCK 2000). É o vetor mais importante da doença de Chagas na Caatinga árida do Nordeste Brasileiro (SCHOFIELD et al. 1987, SCHOFIELD 1994, COSTA 2000), albergando altos índices de infecção pelo T. cruzi. Sua presença tem sido assinalada em algumas regiões de Goiás e Minas Gerais (LENT \& JURBERG 1978); não tem sido encontrada em outros países, além do Brasil.

Nos trabalhos rotineiros de vigilância epidemiológica realizados pela Fundação Nacional de Saúde (FUNASA) em 1997 na região endêmica do país, foi considerada a segunda espécie mais abundante, significando $27,9 \%$ do total de triatomíneos capturados (VINHAES \&DIAS 2000) e destes exemplares $1,44 \%$ apresentaram-se positivos para $T$. cruzi.

\section{Triatoma infestans (Klug, 1834)}

O exemplar considerado tipo, descrito como Reduvius infestans Klug in Meyen 1834, foi coletado na Argentina, em localidade desconhecida, no ano de 1834. Encontra-se conservado no Museu de Zoologia de Berlim, Alemanha.

É uma espécie que se dispersou a partir da Bolívia que é considerada seu centro de endemismo sendo a única região onde tem sido encontrada no ambiente silvestre (LENT \& WYGODZINSKY 1979). Essa espécie está amplamente distribuída através da Argentina, Chile, Sul do Peru, Paraguai, Uruguai e Brasil (SCHOFIELD et al. 1987), países onde é encontrado apenas domiciliado.

T. infestans coloniza facilmente o domicílio humano e no peridomicílios prolifera em galinheiros, pombais, criações de cobaias e coelhos e currais de cabras e carneiros (LENT \& JURBERG 1978). No ambiente silvestre, vive em interstícios de muros de pedra, sob o córtex e ocos das árvores, debaixo de pedras soltas, no solo, em troncos caídos e em ninhos de roedores, marsupiais e ninhos abandonados de aves, servindo de abrigo a pequenos mamíferos. É uma espécie de alta competência vetorial (sempre apresenta altas taxas de infecção pelo $T$. cruzi) e acentuada antropofilia (apresenta-se em altas densidades dentro das moradias).

Por um longo periodo apareceu como principal vetor da doença de Chagas no Brasil e em vários países neotropicais. Particularmente devido às medidas de controle impostas por diversos países, inclusive as do "Pacto do Cone Sul", esta 
espécie está em vias de erradicação, o que tem dado ensejo a que cada região designe a espécie nativa local como tendente a ocupar o nicho ecológico do $T$. infestans erradicado.

Dados da FUNASA mostram como nos anos de 1983 a 1998 o número de municípios com $T$. infestans diminuiu de 711 para apenas 102; a participação relativa no total de capturas caiu de $13,5 \%$ para $0,2 \%$ e as taxas de infecção reduziram de $8,4 \%$ para $2,9 \%$ (VINHÂES \& DIAS 2000).

\section{Triatoma pseudomaculata Correa \& Espínola, 1964}

O exemplar considerado tipo foi coletado no Município de Sobral, Ceará, Brasil. Foi descrito por Corrêa \& Espínola em 1964 e está depositado na Coleção Entomológica do Instituto Oswaldo Cruz, Rio de Janeiro.

Essa espécie ocorre na região Nordeste do Brasil, apresentando uma distribuição semelhante a do T. brasiliensis (SILVEIRA \& REZENDE 1994), com a qual compete na transmissão do $T$. cruzi, nessa região (LINHARES 2000).

Os dados epidemiológicos apresentados pela FUNASA, no ano 1997, da área endêmica para a doença de Chagas, mostraram esta espécie como a terceira mais abundante nas capturas realizadas nos estados brasileiros (VINHAES \& DIAS 2000), sendo que dos 199.143 triatomíneos capturados, $48.145(24,2 \%)$ foram $T$. pseudomaculata. O índice de infecção natural foi de $1,29 \%$.

\section{Triatoma rubrovaria (Blanchard, 1843)}

O exemplar tipo descrito como Conorhinus rubro-varius Blanchard 1843, foi coletado na localidade de Maldonado, Buenos Aires, Argentina e não se conhece o local de depósito do mesmo; só existe o tipo de Conorhinus rubroniger Stal, 1859, depositado no Museu de Berlim, Alemanha.

Segundo LUCENA (1959), sua distribuição geográfica é restrita ao Estado de Rio Grande do Sul, mas LENT \& WYGODZINSKY (1979) e LENT \& JURBERG (1980) informaram-na também no Estado de Paraná. Essa espécie tem sido encontrada naturalmente infetada por $T$. cruzi, ocorrendo raramente nas habitações humanas. Vive preferencialmente em áreas pedregosas, onde convive com pequenos répteis e anfibios. 
No Estado de Rio Grande do Sul, esta espécie tem sido encontrada naturalmente infectada por $T$. cruzi e, algumas vezes, colonizando moradias humanas, provavelmente como resultado da ocupação de espaços abertos pela eliminação do T. infestans (SILVEIRA et al. 1983, SILVEIRA \& REZENDE 1994).

\section{Triatoma sordida (Stal, 1859)}

Embora o exemplar tipo dessa espécie encontre-se depositado no Museu de Zoologia de Berlim, não existem dados exatos da localidade do Brasil, onde foi coletado.

Considera-se uma espécie basicamente silvestre que apresenta marcada ornitofilia; tem seu centro de dispersão no Cerrado da Região Centro Oeste do País (FORATTINI 1980), distribuindo-se nos Estados do Sul do País e propagando-se até Piauí ao Nordeste e Goiás e Mato Grosso ao Centro Oeste (LENT \& JURBERG 1978).

É uma das espécies que apresentam populações mais elevadas no Brasil (SILVEIRA 1983, SILVEIRA \& REZENDE 1994). Localiza-se especialmente em galinheiros peridomiciliares, porém, nos Estado de Minas Gerais, Bahia e sul do Tocantins tem sido encontrada no intradomicílio. No Centro e Sul do Brasil, tem sido coletada numa grande variedade de habitats silvestres, particularmente ninhos de aves, ocos de árvores e debaixo de troncos caídos (GORLA et al. 1993).

Sob o ponto de vista epidemiológico, é considerado um vetor de menor capacidade vetorial, porque sua reprodução é lenta e raras vezes forma colônias grandes. Embora os insetos se infectem facilmente com T. cruzi, o parasita mostra baixa taxa reprodutiva de tripomastigotas metacíclicos (SCHOFIELD 1994). Mesmo assim, é considerado vetor da doença de Chagas no Brasil Central (SILVEIRA 2000).

Desde 1995, tinha sido considerada a espécie triatomínea mais comum no Brasil (DIOTAIUTI et al. 1995). Este fato foi confirmado pelos dados epidemiológicos apresentados pela FUNASA em 1997, quando assinalara esse vetor como o mais abundante nas capturas realizadas na área endêmica do país (VINHAES \& DIAS 2000), apresentando um volume de captura de 81.970 exemplares $(41,2 \%$ do total). 


\section{Triatoma tibiamaculata (Pinto, 1926)}

O exemplar tipo dessa espécie foi coletado na localidade de Japuyba, Angra dos Reis, Rio de Janeiro, Brasil, em 1926. Está depositado na Coleção Entomológica do Instituto Oswaldo Cruz, Rio de Janeiro.

Essa espécie tem sido encontrada nos Estados da Bahia, Espírito Santo, Minas Gerais, Paraná, Rio de Janeiro, São Paulo, Santa Catarina e Sergipe (LENT \& WYGODZINSKY 1979, LENT \& JURBERG 1980), particularmente encontrado com muita freqüência na região litorânea desses estados. Ocorre junto a ninhos de marsupiais dos gêneros Didelphis e Marmosa e roedores; alguns espécimes têm sido achados em bromélias epífitas.

É freqüente encontrá-la invadindo domicílios em áreas não chagásicas, como o litoral do Estado de São Paulo, onde embora seja achado naturalmente infectado com $T$. cruzi e, às vezes, até detectado preferência por sangue humano, não tem sido encontrado domiciliado.

Dados fornecidos pela SUCEN, sobre exemplares triatomíneos capturados entre 1953 e 1974 em municípios do litoral do Estado de São Paulo, revelaram a presença de formas tripomastigotas do T. cruzi em suas fezes (TAKEDA et al. 1976).

Os dados sobre capturas de triatomíneos realizadas pela FUNASA no ano de 1997 mostraram que apesar de ser T. tibiamaculata uma espécie pouco freqüente $(0,005 \%)$, a porcentagem de infecção natural foi alta (10\%) (VINHÃES \& DIAS 2000).

\section{Triatoma vitticeps (Stal, 1859)}

O exemplar tipo dessa espécie foi coletado na localidade de Conceição de Macabú, Rio de Janeiro, Brasil. Foi descrito por Stal, em 1859, como Conorhinus vitticeps, sendo o tipo depositado no Museu de Zoologia de Berlim, Alemanha.

Essa espécie distribui-se na região Sudeste, em Minas Gerais, Rio de Janeiro e Espírito Santo. Foi referida sua presença no Estado de Rio Grande do Sul (LUCENA 1959). Tem sido achada naturalmente infetada com T. cruzi (LENT \& WYGODZINSKY 1979). Embora alguns autores (LENT \& JURBERG, 1978), 
informaram como uma espécie domiciliada, dados recentes (GONÇALVES et al. 1998) confirmaram que continua sendo uma espécie silvestre.

\subsection{Estudo morfológico do Processo do I Urotergito (PIU)}

\subsubsection{Descrição do Processo do I Urotergito}

O Processo do I Urotergito é formado por uma estrutura plana e retangular, constituída pelo conjunto do $1^{\circ}$ e $2^{\circ}$ urotergitos. Tal processo está situado na região dorsal, abaixo do escutelo e da base de implantação das asas anterior e posterior (BARATA et al. 1996a).

Este processo é formado por duas placas superpostas, uma superior, o primeiro urotergito, formado por uma placa triangular de tamanho quase sempre menor que a metade do segundo urotergito, cuja base desse triangulo está voltada para a região anterior e faz divisa dorsal entre o tórax e o abdome; seu ápice está projetado para a região mediana do segundo urotergito. $\mathrm{O} 2^{\circ}$ urotergito está formado por uma placa retangular, cuja região anterior está parcialmente coberta pelo $1^{\circ}$ urotergito; na junção dos dois urotergitos existem estruturas com configurações que diferem de acordo com a espécie triatomínea considerada, tais como estrias e cerdas (Fig. 2).

Circundando o ápice do triângulo formado pelo $1^{\circ}$ urotergito, existe uma área esférica, escavada e que foi denominada como Área Circular. Via de regra, a borda inferior dessa área não atinge o limite posterior do $2^{\circ}$ urotergito.

Geralmente, o $1^{\circ}$ urotergito apresenta-se em um plano superior em relação ao $2^{\circ}$ urotergito, sendo mais marcada tal característica ao nível da Área Circular. 


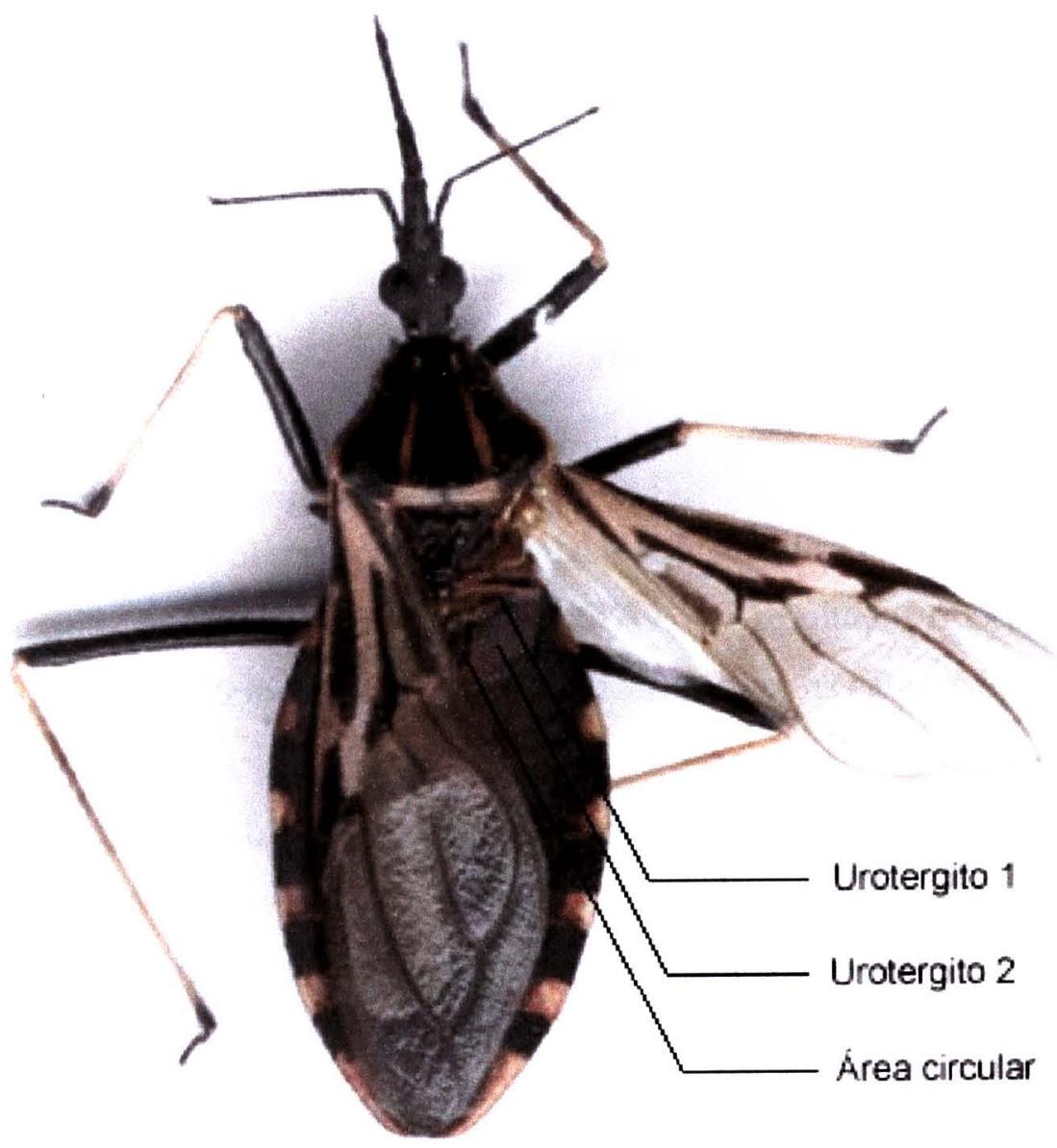

Figura 2- Tórax de inseto adulto macho de Triatoma tibiamaculata (Pinto, 1926) (Hemiptera, Reduviidae) com asas direitas abertas para visualizar as estruturas do Processo do I Urotergito. 


\subsubsection{Características morfológicas do Processo do I Urotergito segundo espécies}

Para cada uma das espécies são detalhadas as observações morfológicas sobre o PIU.

Apresentam-se para cada espécie as seguintes ilustrações: adulto para visualizar a localização do Processo do I Urotergito ${ }^{\prime}(\mathrm{A})$, foto em Microscopia Óptica do Processo do I Urotergito (B), desenho esquemático em câmara clara do Processo do I Urotergito (C) e foto em Microscopia Eletrônica de Varredura do Processo do I Urotergito (D).

\subsubsection{Gênero Panstrongylus}

Com base nas observações realizadas nesta pesquisa em relação ao Processo do I Urotergito da espécie P. megistus (Fig. 3) e nos resultados obtidos no trabalho de BARATA et al. (1996c) para P. herreri, descrevem-se as características do gênero Panstrongylus.

Em vista dorsal, a placa triangular aparece em um plano mais elevado em relação à placa retangular.

$\mathrm{O} 1^{\circ}$ Urotergito apresenta forma triangular ou trapezoidal, com ápice pouco pronunciado e ponta romba, aparecendo uniformemente coberto por perceptíveis estrias verticais paralelas de aspecto rugoso e ramificado; na região próxima ao ápice apresenta um par de estrias verticais paralelas alongadas e retas, com curvatura pouco acentuada nas extremidades inferiores. Observa-se uma estria mediana semelhante a uma carena que se estende da borda anterior ao ápice; aparecem cerdas distribuídas principalmente na região central.

O $2^{\circ}$ urotergito apresenta estrias horizontais paralelas e lisas ou com discreta rugosidade que surgem nas bordas laterais da Área Circular e se estendem até as borda laterais da placa.

A Área Circular apresenta forma de ferradura sem ornamentação definida.

\footnotetext{
1 Por esse motivo deixou-se de apresentar a referida escala.
} 


\section{Panstrongylus megistus (Burmeister, 1835)}

Foram estudadas apenas duas amostras desta espécie, que eram procedentes de áreas epidemiologicamente diferentes. A primeira amostra (CTA 145), procedente do Município de Almino Afonso - RN, e a segunda (CTA 151), procedente de Curitiba-PR. As duas amostras do $P$ megistus não apresentam diferenças estruturais significativas quando comparados os desenhos de câmara clara, as imagens digitais e as fotografias de microscópio eletrônico de varredura.

O $1^{\circ}$ urotergito dessa espécie apresenta forma de triângulo e ligeiramente globosa, com ápice muito evidente e rombo. Essa estrutura possui em toda a sua extensão estrias rugosas, verticais, irregulares e ramificadas que saem paralelas no centro, curvando-se nas extremidades (Fig. 3D). Observa-se nessa área a presença de numerosas cerdas dispostas em linhas horizontais, principalmente na região central.

O $2^{\circ}$ urotergito apresenta estrias horizontais e paralelas que surgem nas bordas laterais da Área Circular e se estendem até as bordas laterais dessa, formando um desenho semicircular em torno da placa circular.

$\mathrm{O}$ ápice do $1^{\circ}$ urotergito repousa sobre a região mediana da Área Circular do $2^{\circ}$ urotergito, tomando o conjunto a forma de ferradura. Ambas as porções são desprovidas de cerdas (Fig. 3C).
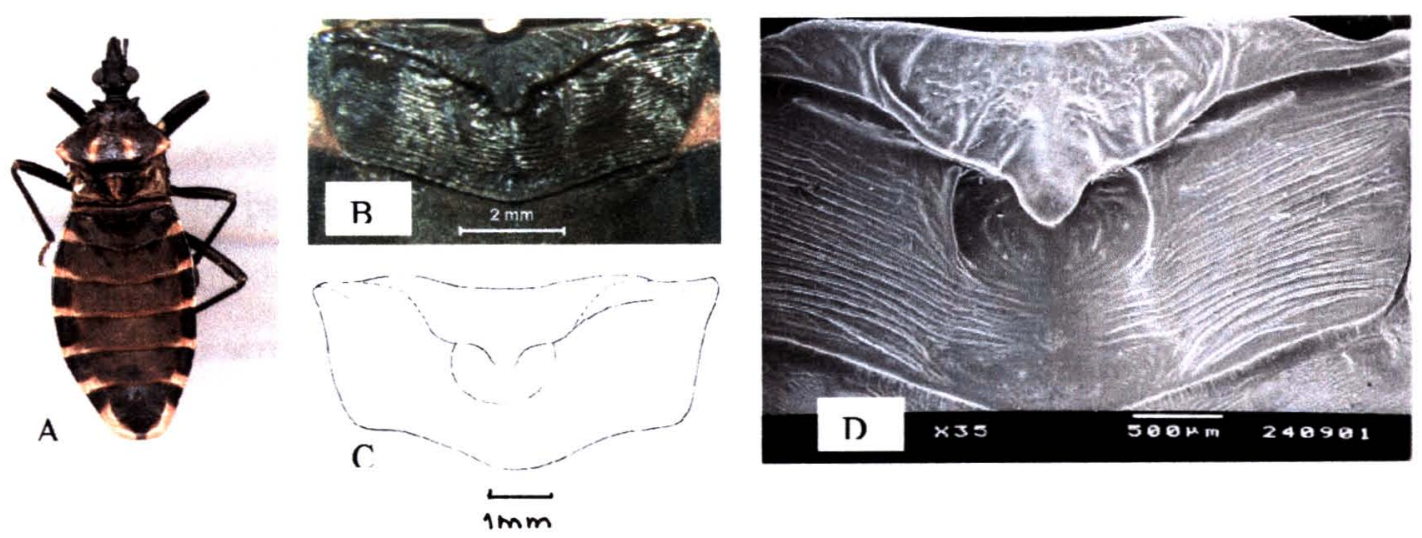

Figura 3- Panstrongylus megistus (Burmeister, 1835). A. Vista dorsal do abdome do adulto macho em microscópio óptico. B. Vista dorsal do Processo do I Urotergito em microscópio digital. C. Vista dorsal do Processo do I Urotergito em câmara clara. D. Vista dorsal do Processo do I Urotergito em microscópio eletrônico de varredura. 
$\mathrm{O} 1^{\circ}$ urotergito de $P$. megistus apresenta ápice rombo com bordas elevadas; estrias verticais, paralelas e rugosas aparecem distribuídas na superficie da placa; as cerdas aparecem espalhadas irregularmente na superficie.

Em relação ao $2^{\circ}$ urotergito, foram observadas estrias horizontais lisas e paralelas distribuídas uniformemente, que atingiram as bordas laterais da placa. As observações anteriores concordam com as realizadas por BARATA et al. (1996c) para $P$. megistus.

A Área Circular apresentou forma de ferradura, sendo que as estrias grossas delimitantes dessa região mostraram discreta convergência.

\subsubsection{Gênero Rhodnius}

Com base nas observações realizadas em relação ao Processo do I Urotergito das espécies $R$. nasutus, $R$. neglectus, $R$. prolixus obtidas nesta pesquisa (Figs. 4, 5 e 6) e os resultados obtidos para $R$. robustus nos trabalhos de BARATA et al. $\left(1996^{\mathrm{a}}\right.$, 1998a), se descrevem as características genéricas do Rhodnius.

Em vista dorsal o $1^{\circ}$ urotergito aparece localizado em um nível superior em relação ao $2^{\circ}$ urotergito, apresentando o ápice rombo ou pontiagudo (Figs $4 \mathrm{D}$ e 5D ).

$\mathrm{O} 1^{\circ}$ urotergito apresenta estrias verticais lisas ou rugosas e ramificadas com discreto paralelismo lateral em toda a superfície. Próximos dos vértices e da região central observam-se depressões nas bordas laterais em continuidade com o ápice.

Podem aparecer diminutas cerdas distribuídas irregularmente sobre a superfície da placa na região central do $2^{\circ}$ urotergito; observam-se entre cinco e onze estrias verticais paralelas, lisas ou rugosas, simples ou ramificadas, concêntricas ou não em continuidade com a arquitetura do $1^{\circ}$ urotergito. $O$ resto dessa placa tem aspecto glabro sem ornamentação definida.

A Área Circular está localizada abaixo do ápice do $1^{\circ}$ urotergito; seu tamanho é muito reduzido; apresenta forma ovóide, sendo que seu extremo apical pode ser aberto ou fechado e não apresenta ornamentação definida. 


\section{Rhodnius nasutus Stal, 1859}

Em vista dorsal, o $1^{\circ}$ urotergito ou placa triangular aparece localizado em nível superior em relação ao $2^{\circ}$ urotergito, característica esta mais evidente na região do ápice que termina de forma pontiaguda.

No $2^{\circ}$ urotergito ou placa retangular, observam-se de cinco a nove estrias não concêntricas, a cada lado da Área Circular e dispostas nos sentidos vertical e paralelo; as estrias mais internas da Área Circular contornam esta área, fechando-a e reduzindo-a a pequena área ovóide situada logo abaixo do ápice do $1^{\circ}$ urotergito (Fig. 4D).
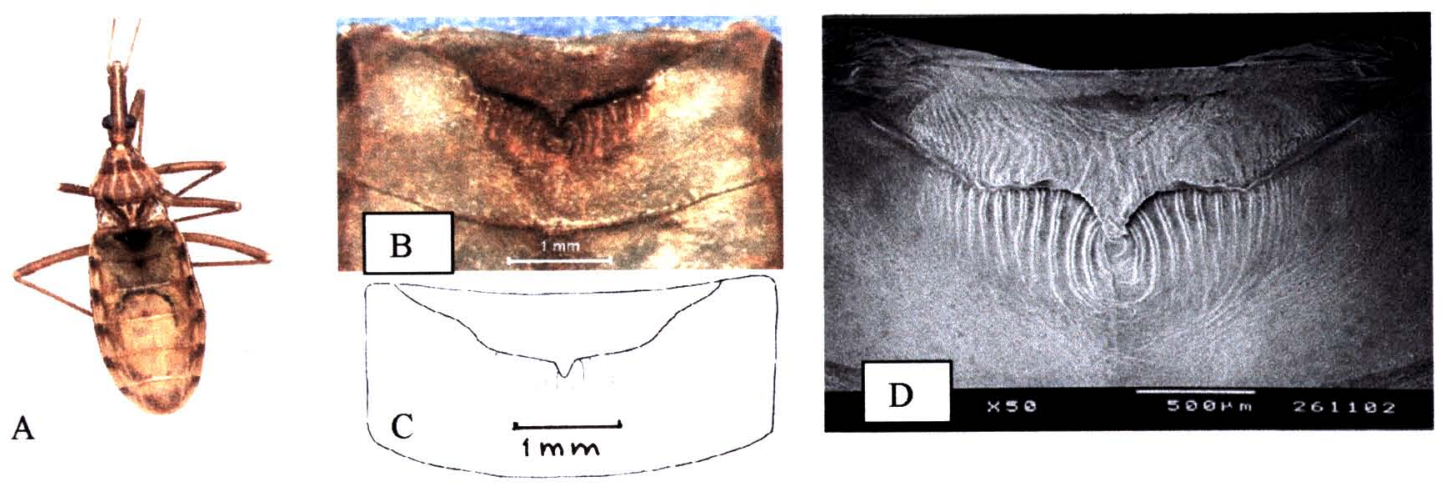

Figura 4- Rhodnius nasutus Stal, 1859. A. Vista dorsal do abdome do adulto macho em microscópio óptico. B. Vista dorsal do Processo do I Urotergito em microscópio digital. C. Vista dorsal do Processo do I Urotergito em câmara clara. D. Vista dorsal do Processo do I Urotergito em microscópio eletrônico de varredura. 


\section{Rhodnius neglectus Lent, 1954}

Em vista dorsal, o $1^{\mathrm{o}}$ urotergito ou placa triangular aparece localizado em nível superior ao $2^{\circ}$ urotergito, característica esta mais evidente na região do ápice que termina de forma romba.

No $2^{\circ}$ urotergito observam-se de oito a onze estrias rugosas, não concêntricas, a cada lado da Área Circular e dispostas em sentido vertical e paralelo; as estrias mais internas da Área Circular contornam esta área, fechando-a e reduzindo-a a pequena área ovóide, mas deixando abertas as estrias mas externas (Fig. 5C).
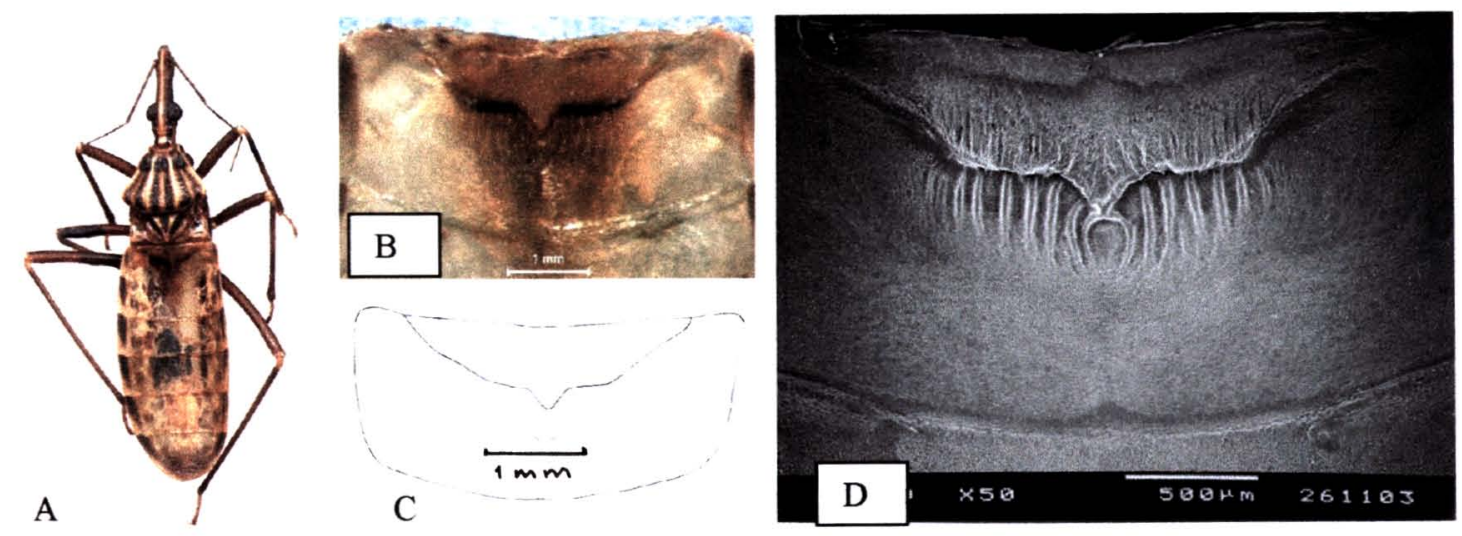

Figura 5- Rhodnius neglectus Lent, 1954. A. Vista dorsal do abdome do adulto macho em microscópio óptico. B. Vista dorsal do Processo do I Urotergito em microscópio digital. C. Vista dorsal do Processo do I Urotergito em câmara clara. D. Vista dorsal do Processo do I Urotergito em microscópio eletrônico de varredura. 


\section{Rhodnius prolixus Stal, 1859}

Em vista dorsal, o $1^{\circ}$ urotergito ou placa triangular aparece localizado em nível superior ao $2^{\circ}$ urotergito, característica esta mais evidente na região do ápice que termina de forma pontiaguda. Próximo dos vértices e da região central dessa placa, observam-se depressões nas bordas laterais em continuidade com o ápice.

No $2^{\circ}$ urotergito, observam-se de oito a onze estrias lisas, não concêntricas, a cada lado da Área Circular e dispostas nos sentidos vertical e paralelo; as estrias mais internas da Área Circular contornam esta área, fechando-a e reduzindo-a a pequena área ovóide situada logo abaixo do ápice do $1^{\circ}$ urotergito (Fig. $6 \mathrm{C}$ e D).
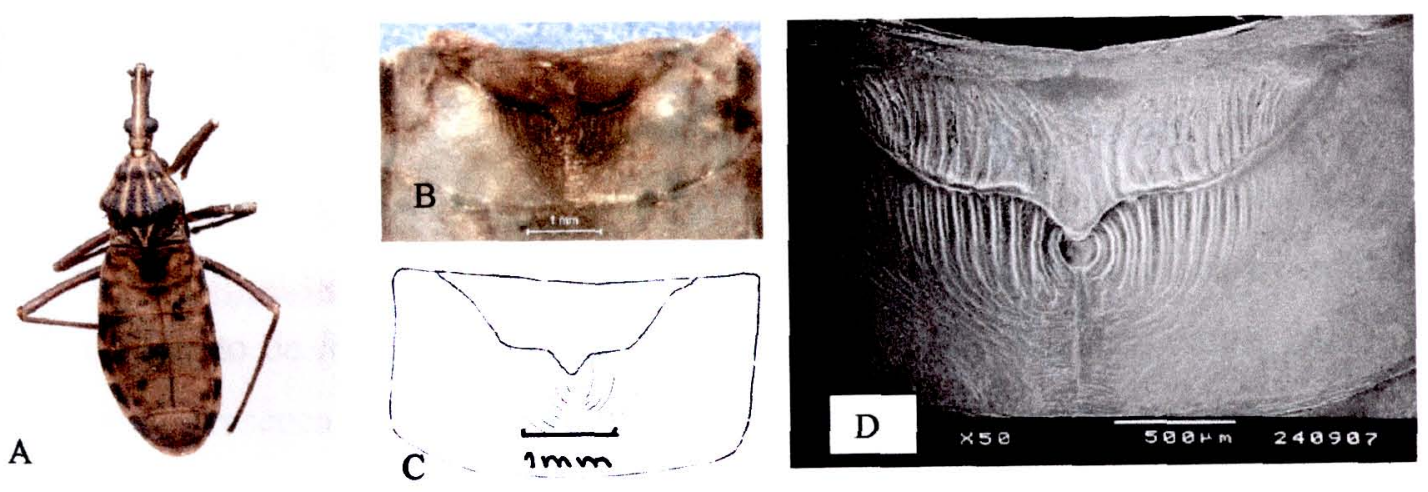

Figura 6- Rhodnius prolixus Stal, 1859. A. Vista dorsal do abdome do adulto macho em microscópio óptico. B. Vista dorsal do Processo do I Urotergito em microscópio digital. C. Vista dorsal do Processo do I Urotergito em câmara clara. D. Vista dorsal do Processo do I Urotergito em microscópio eletrônico de varredura.

O ápice do Processo I Urotergito de $R$. nasutus e $R$. prolixus apresentou forma pontiaguda, diferente de $R$. neglectus que apresentou uma configuração romba. Da mesma forma o $1^{\circ}$ urotergito e a Área Circular das espécies $R$. nasutus e $R$. neglectus foram caracterizadas pela presença de estrias rugosas e ramificadas, enquanto que em $R$. prolixus, as estrias são lisas. Esses resultados concordam com as observações de BARATA et al. (1996b e 1998a) e permitem diferenciar as três espécies.

As observações sobre a forma pontiaguda do ápice do $1^{\circ}$ urotergito nas espécies $R$. nasutus e $R$. prolixus permitem diferenciá-las do $R$. robustus, que 
apresenta o ápice rombo (BARATA et al. 1998a). Esta característica podem ser importante para diferenciar entre $R$. prolixus e $R$. robustus, já que ambas são muito próximas e apresentam grande semelhança morfológica (MONTEIRO et.al. 2000) e enzimática (HARRY et.al. 1992).

Uma característica adicional que permite separar as três espécies de Rhodnius é o número de estrias paralelas àquelas que delimitam a Área Circular. Na espécie $R$. nasutus observa-se um número menor de estrias, entre 5 e 9 , enquanto que em $R$. neglectus e $R$. prolixus observara-se um número maior, entre 8 e 11.

Em relação à comparação da forma da Área Circular nas espécies de Rhodnius estudadas, observam-se discretas diferenças. As três espécies, $R$. nasutus, $R$. neglectus e $R$. prolixus apresentam área circular ovóide, pequena, contornada por inúmeras estrias concêntricas que se estendem lateralmente ao corpo do $2^{\circ}$ urotergito. A estria mais próxima da área circular pode fechar tal área, como em $R$. prolixus e $R$. nasutus e pode deixá-la aberta no sentido inferior como em $R$. neglectus.

Em relação à presença de cerdas nas três espécies de Rhodnius, essas foram evidentes tanto na superfície do $1^{\circ}$ urotergito e na área próxima da placa triangular no $2^{\circ}$ urotergito de $R$. prolixus, sendo que apresentaram tamanho diminuto; não foi observada a presença de cerdas nas outras espécies. 


\subsubsection{Gênero Triatoma}

Com base nas observações realizadas em relação ao Processo do I Urotergito das espécies T. brasiliensis, T. delpontei Romaña \& Abalos, 1947, T. infestans, $T$. lecticularia (Stal, 1859), T. platensis Neiva, 1913, T. pseudomaculata, T. protracta (Uhler, 1894), T. rubrovaria, T. sordida, T. tibiamaculata e T. vitticeps obtidas nos trabalhos de BARATA et al. (1996b, 1998b, 1999a, 1999b) e nesta pesquisa, descrevem-se as características genéricas do Triatoma.

$O 1^{\circ}$ urotergito localiza-se em nível superior ao $2^{\circ}$ urotergito, apresentando o ápice curto ou pronunciado e de configuração romba, pontiaguda ou espiralada; apresenta arquitetura triangular ou trapezoidal; algumas estrias verticais paralelas aparecem concentradas nas bordas laterais e na região centro apical; algumas cerdas aparecem distribuídas principalmente na região central da placa e podem ser curtas ou longas.

O $2^{\circ}$ urotergito apresenta duas estrias grossas paralelas entre si, concêntricas ou divergentes que delimitam a Área Circular; podem aparecer estrias horizontais paralelas ao ápice do $1^{\circ}$ urotergito que se estendem em toda a placa retangular e estriação vertical ou oblíqua paralela ou não às duas estrias grossas. Em alguns casos existe estriação formada por ondulações rugosas tanto em sentido horizontal como vertical, formando uma configuração semelhante a tecido de renda, que percorre as áreas laterais dessa placa. Algumas cerdas diminutas podem aparecer esparsas por toda a placa retangular.

A Área Circular está delimitada por um par de estrias grossas; pode apresentar configuração oval, em ferradura, semicircular, arredondada, de feijão ou de coração. Sob o ponto de vista da área que ocupa, pode estender-se até a região mediana ou atingir o extremo apical do $2^{\circ}$ urotergito; pode ser aberta apicalmente ou estar delimitada por conspícuo sulco perpendicular às estrias grossas verticais; pode formar uma profunda concavidade ou aparecer superficialmente demarcada; pode apresentar estrias horizontais paralelas entre si ou aparecer sem ornamentação definida. 


\section{Triatoma brasiliensis Neiva, 1911}

T. brasiliensis apresenta, em vista dorsal, o $1^{\circ}$ urotergito em um plano superior, quando comparado ao do $2^{0}$ urotergito. $\mathrm{O}$ aspecto geral é liso, sem ornamentação, com estrias e nervuras discretas. $\mathrm{O}$ ápice dessa placa apresenta forma pontiaguda e se aloja na Área Circular côncava, localizada na região central do $2^{\circ}$ urotergito.

O $2^{\circ}$ urotergito apresenta leves estrias na superfície. Embaixo das regiões laterais, próximas do ápice do $1^{\circ}$ urotergito, visualizam-se algumas linhas estriadas, orientadas paralelamente a ele (Fig. 7D).

A Área Circular aparece como uma configuração em ferradura sem ornamentação (Fig. 7B e 7C).
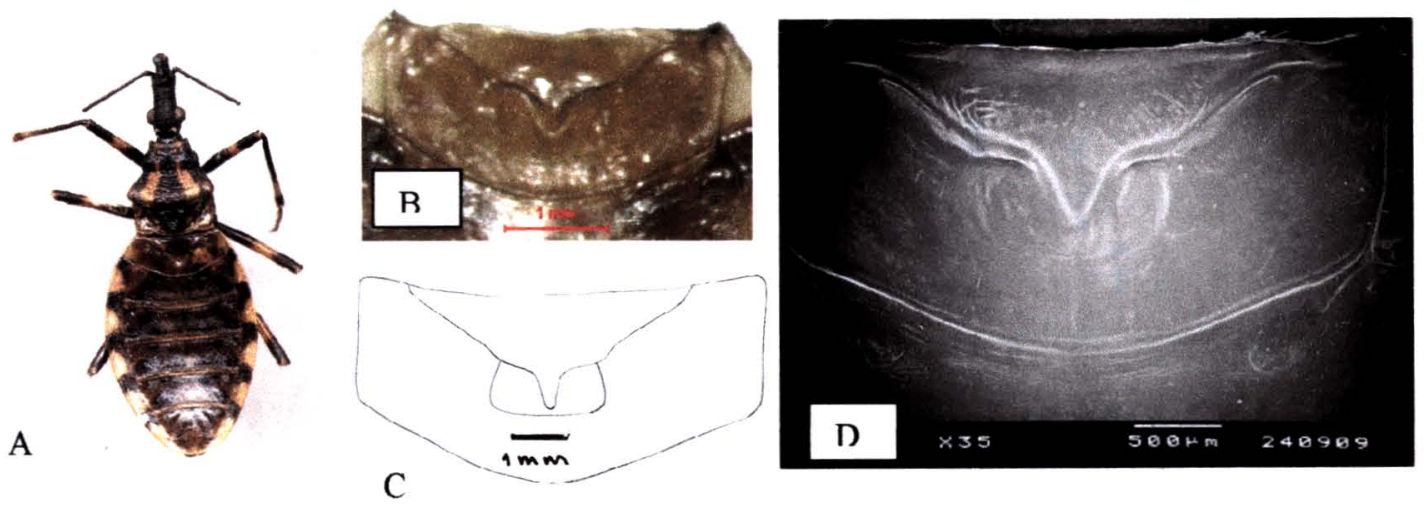

Figura 7- Triatoma brasiliensis Neiva, 1911. A. Vista dorsal do abdome do adulto macho em microscópio óptico. B. Vista dorsal do Processo do I Urotergito em microscópio digital. C. Vista dorsal do Processo do I Urotergito em câmara clara. D. Vista dorsal do Processo do I Urotergito em microscópio eletrônico de varredura. 


\section{Triatoma infestans (Klug, 1834)}

$\mathrm{O} 1^{\mathrm{o}}$ urotergito de $T$. infestans apresenta arquitetura trapezoidal. $\mathrm{O}$ ápice da placa triangular é curto e rombo com um discreto processo angular na região mediana da base menor do trapézio; algumas estrias verticais aparecem concentradas nas bordas laterais (Fig. 8D). Aparecem cerdas localizadas particularmente na área central.

$\mathrm{Na}$ superfície basal das áreas laterais do $2^{\circ}$ urotergito aparecem estrias verticais paralelas às duas estrias grossas que delimitam a Área Central, apresentando evidente rugosidade (Fig. 8B); de maneira semelhante acontece em toda a extensão da área apical, sendo que as estrias são horizontais e perpendiculares às estrias grossas.

A Área Central apresenta forma de semicírculo e está delimitada lateralmente por duas estrias verticais, pronunciadas, paralelas e com curvatura acentuada (Figs. $8 \mathrm{~B}$ e $8 \mathrm{C}$ ). Apicalmente se estende até a região mediana do $2^{\circ}$ urotergito. Observa-se pouca ornamentação nessa área.
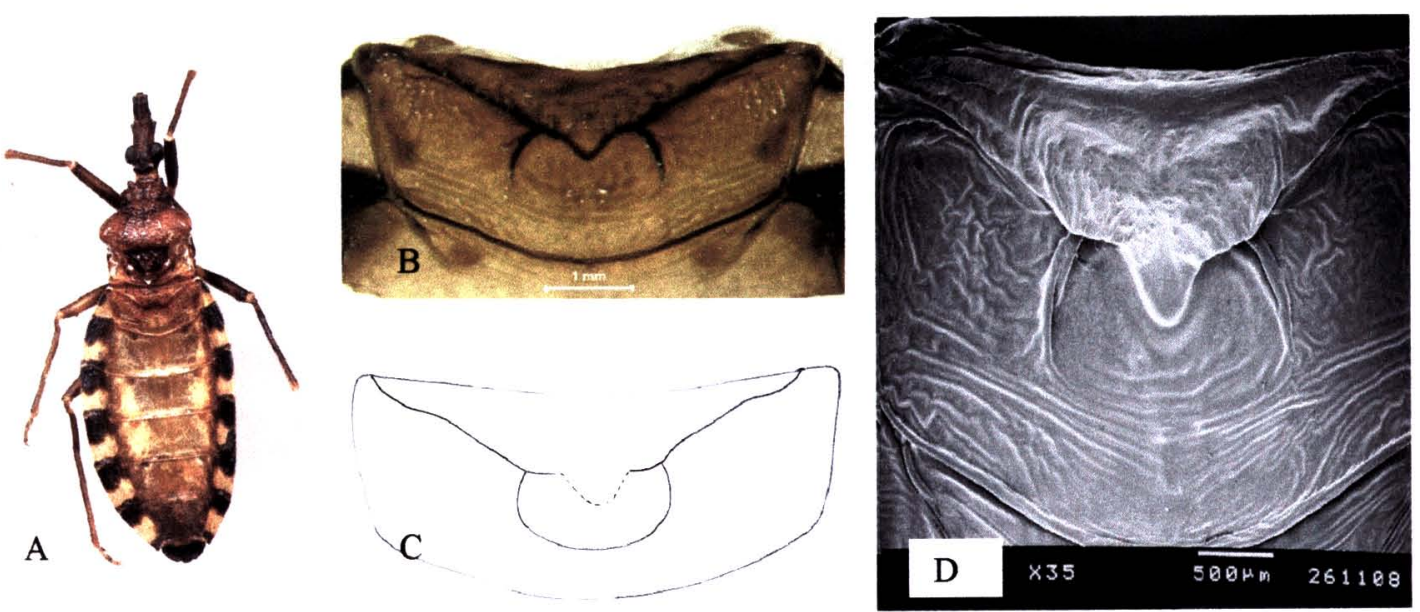

Figura 8- Triatoma infestans (Klug, 1834). A. Vista dorsal do inseto adulto macho com as asas destacadas em microscópio óptico. B. Vista dorsal do Processo do I Urotergito em microscópio digital. C. Vista dorsal do Processo do I Urotergito em câmara clara. D. Vista dorsal do Processo do I Urotergito em microscópio eletrônico de varredura. 


\section{Triatoma pseudomaculata Correa \& Espínola, 1964}

O $1^{\circ}$ urotergito dessa espécie está localizado em um plano superior ao $2^{\circ}$ urotergito. A placa triangular apresenta cerdas distribuídas principalmente nas bordas laterais próximas à declinação do ápice. Essa estrutura apresenta um declive moderado e termina em uma ponta aguçada. Algumas estrias verticais localizam-se nas bordas laterais (Fig. 9D).

O $2^{\circ}$ urotergito apresenta algumas estrias oblíquas paralelas, próximas da Área Circular (Fig. 9D).

A Área Circular apresenta forma arredondada e encontra-se localizada aproximadamente no centro do $2^{\circ}$ urotergito; está delimitada por um par de grossas estrias paralelas, que se estendem nitidamente da parte media apical da placa triangular até a parte média da placa retangular, sendo que dessa localização até a sutura apical do $2^{\circ}$ urotergito aparecem levemente definidas (Fig. 9C). Paralelas às estrias grossas, observam-se estrias menores espalhadas nas áreas laterais do $2^{\circ}$ urotergito (Fig. 9D).
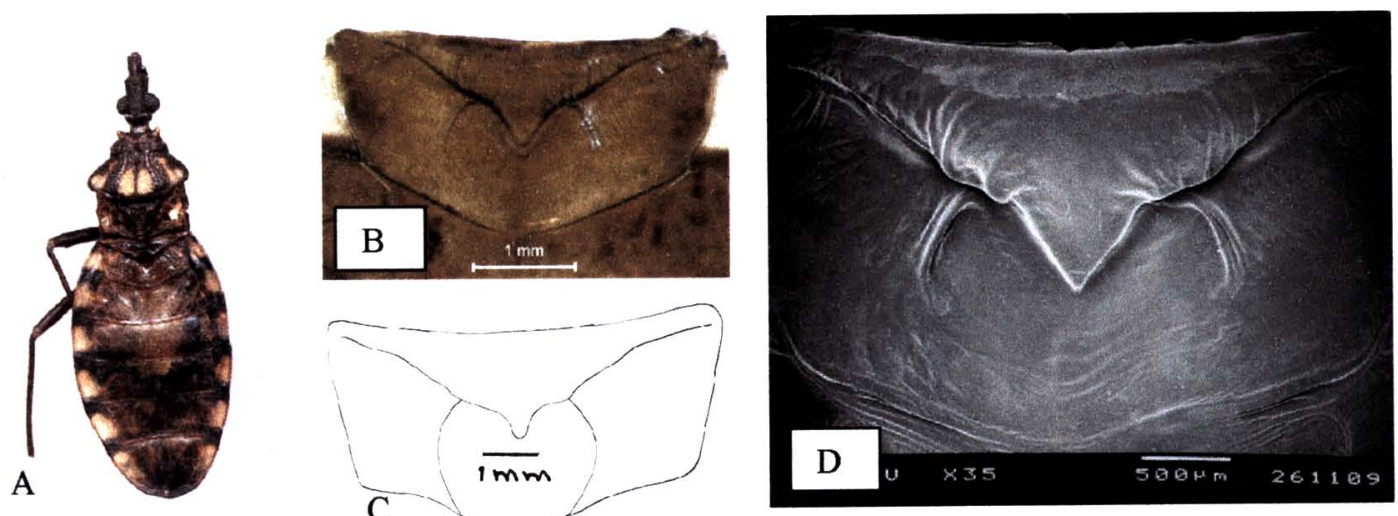

Figura 9- Triatoma pseudomaculata Correa \& Espínola, 1964. A. Vista dorsal do abdome do adulto macho em microscópio óptico. B. Vista dorsal do Processo do I Urotergito em microscópio digital. C. Vista dorsal do Processo do I Urotergito em câmara clara. D. Vista dorsal do Processo do I Urotergito em microscópio eletrônico de varredura. 


\section{Triatoma rubrovaria (Blanchard, 1843)}

T. rubrovaria apresenta o $1^{\mathrm{o}}$ urotergito, em vista dorsal em plano mais elevado do que o $2^{\circ}$. O ápice em geral é pontiagudo; apresentando declive bastante pronunciado.

A placa triangular nessa espécie tem aspecto trapezoidal e mostra rugosidade concentrada nas bordas laterais e na região centro-apical; apresenta em aumentos maiores cerdas longas nas bordas latero-basais, semelhantes às de $T$. delpontei (BARATA et al. 1999a) que, entretanto devido ao pequeno tamanho das fotos apresentadas, não é possível esta visualização.

$\mathrm{O} 2^{\circ}$ urotergito apresenta um par de estrias verticais divergentes que delimitam a Área Circular; em toda a extensão da área adjacente observa-se presença de estrias paralelas. Na região posterior da Área Circular, observam-se estrias horizontais paralelas que se estendem por toda a placa retangular.

A Área Circular apresenta forma oval com pouca ornamentação (Fig. 10C).
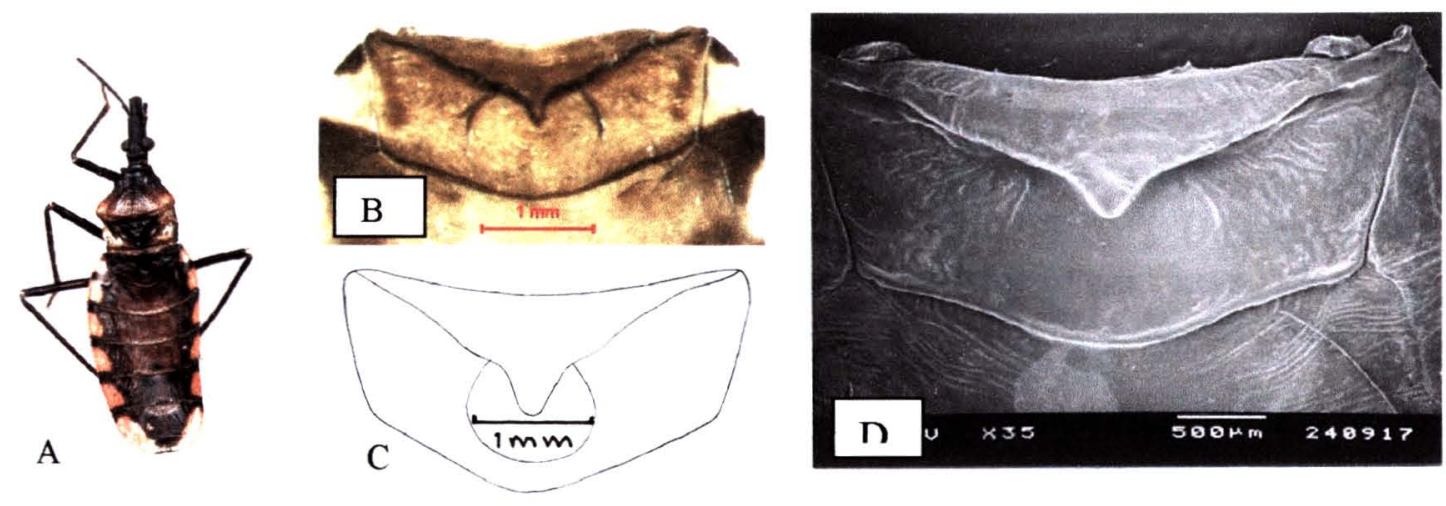

Figura 10- Triatoma rubrovaria (Blanchard, 1843). A. Vista dorsal do abdome do adulto macho em microscópio óptico. B. Vista dorsal do Processo do I Urotergito em microscópio digital. C. Vista dorsal do Processo do I Urotergito em câmara clara. D. Vista dorsal do Processo do I Urotergito em microscópio eletrônico de varredura. 


\section{Triatoma sordida (Stal, 1859)}

$\mathrm{O} 1^{\circ}$ urotergito apresenta forma triangular com ápice pontiagudo e declinado pronunciadamente em direção à Área Circular do $2^{\circ}$ urotergito. Não foi visualizada a presença de cerdas nessa placa. Um aspecto rugoso nota-se tanto no $1^{\circ}$ quanto no $2^{\circ}$ urotergito, onde foram evidentes alguns sulcos, principalmente na região central apical do $2^{\circ}$ urotergito que são paralelos ao ápice do $1^{\circ}$ urotergito (Fig. 11B).

A Área Circular apresenta forma de feijão e se estende somente até a região média do $2^{\circ}$ urotergito, estando delimitada apicalmente por conspícuo sulco perpendicular às estrias grossas e verticais (Fig. 11D).
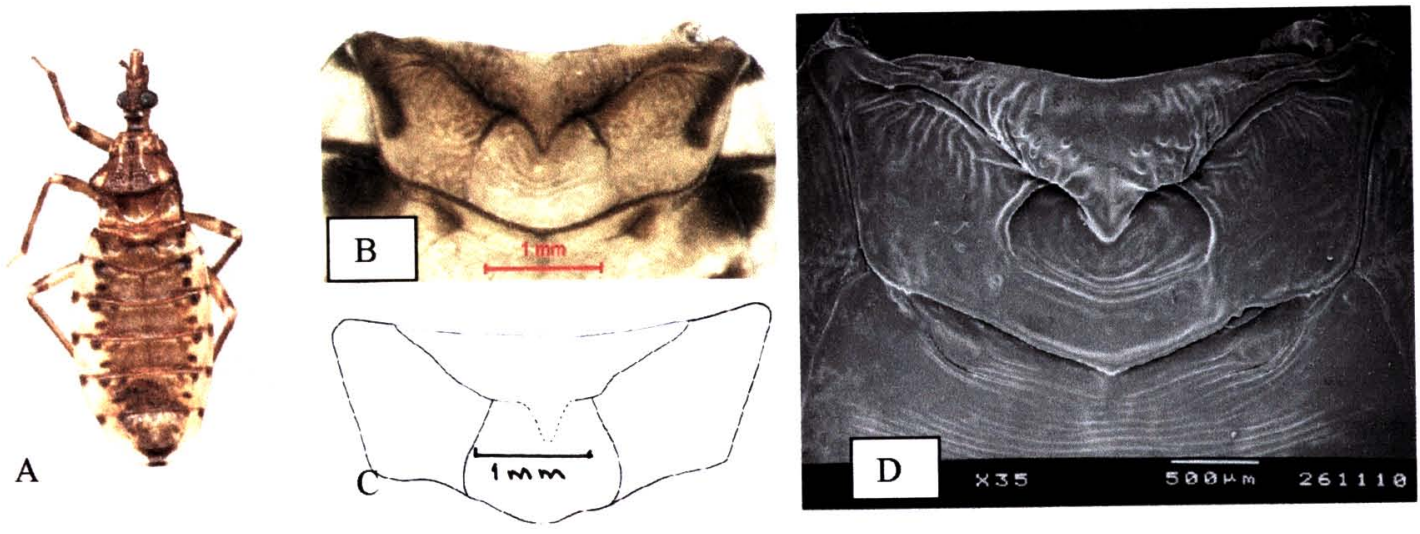

Figura 11- Triatoma sordida (Stal, 1859). A. Vista dorsal do abdome do adulto macho em microscópio óptico. B. Vista dorsal do Processo do I Urotergito em microscópio digital. C. Vista dorsal do Processo do I Urotergito em câmara clara. D. Vista dorsal do Processo do I Urotergito em microscópio eletrônico de varredura. 


\section{Triatoma tibiamaculata (Pinto, 1926)}

O Processo do I Urotergito dessa espécie apresentou conspícuas estriações em sentido dorsal, tanto na placa triangular quanto na retangular, sendo que elas são mais evidentes na primeira estrutura (Figs $12 \mathrm{~B}, \mathrm{C}$ e D). No $1^{\circ}$ urotergito as estriações são formadas por linhas verticais que atravessam a estrutura em sentido longitudinal e paralelas entre si. Na região mediana da placa triangular forma-se uma depressão que vai declinando até quase atingir a concavidade da Área Circular, onde apresenta um ápice com ponta espiralada (Fig 12B e 12C).
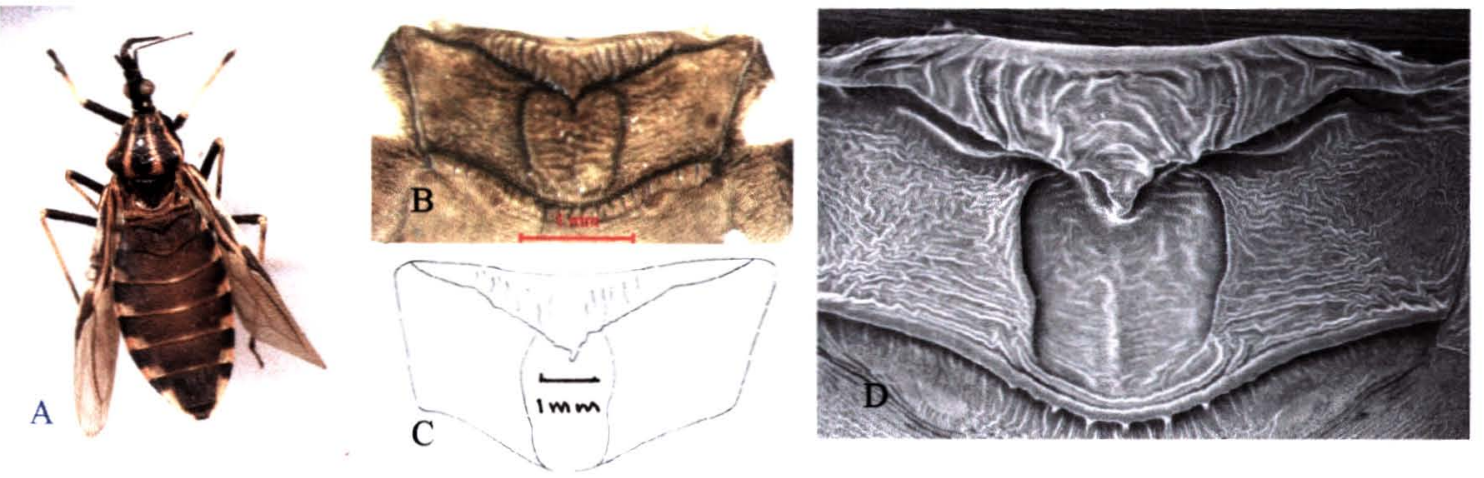

Fig. 12- Triatoma tibiamaculata (Pinto, 1926). A. Vista dorsal do abdome do adulto macho em microscópio óptico. B. Vista dorsal do Processo do I Urotergito em microscópio digital. C. Vista dorsal do Processo do I Urotergito em câmara clara. D. Vista dorsal do Processo do I Urotergito em microscópio eletrônico de varredura (35X).

Já no $2^{\circ}$ urotergito as estriações estão formadas por ondulações rugosas, tanto em sentido horizontal como vertical, formando uma configuração semelhante a tecido de renda, que percorre a placa em sua maior extensão, sendo interceptadas por duas estrias grossas que delimitam a Área Circular central (Fig. 12D).

A Área Circular está formada por uma profunda concavidade apresentando forma de coração, cujas estrias laterais demarcantes se abrem na parte posterior para unir-se à borda apical que forma a base menor do trapézio invertido formado pelo $2^{\circ}$ urotergito. Dentro dessa área existem estrias horizontais, paralelas entre si (Fig. $12 \mathrm{C})$. 


\section{Triatoma vitticeps (Stal, 1859)}

A placa triangular de $T$. vitticeps apresenta estrias verticais paralelas, nas áreas laterais. $\mathrm{O}$ ápice do $1^{\circ}$ urotergito aparece pronunciado e pontiagudo e apresenta acentuada declinação na região central (Fig. 13B).

O $2^{\circ}$ urotergito apresenta estrias verticais nas áreas laterais próximas do $1^{\circ}$ urotergito e estrias horizontais nas porções apicais das áreas laterais. Cerdas pequenas aparecem esparsas tanto no $1^{\circ}$ quanto no $2^{\circ}$ urotergito, porém, devido ao pequeno aumento das fotos apresentadas, não é possível esta visualização.

A Área Circular apresenta forma oval e encontra-se delimitada lateralmente por duas grossas estrias verticais divergentes, cujos extremos atingem a região média do $2^{\circ}$ urotergito; a região apical mostra-se aberta em direção à borda apical do $2^{\circ}$ urotergito. No centro dessa região observa-se uma estria horizontal, curvada e paralela ao ápice da placa triangular do $1^{\circ}$ urotergito (Fig. 13B e 13D).
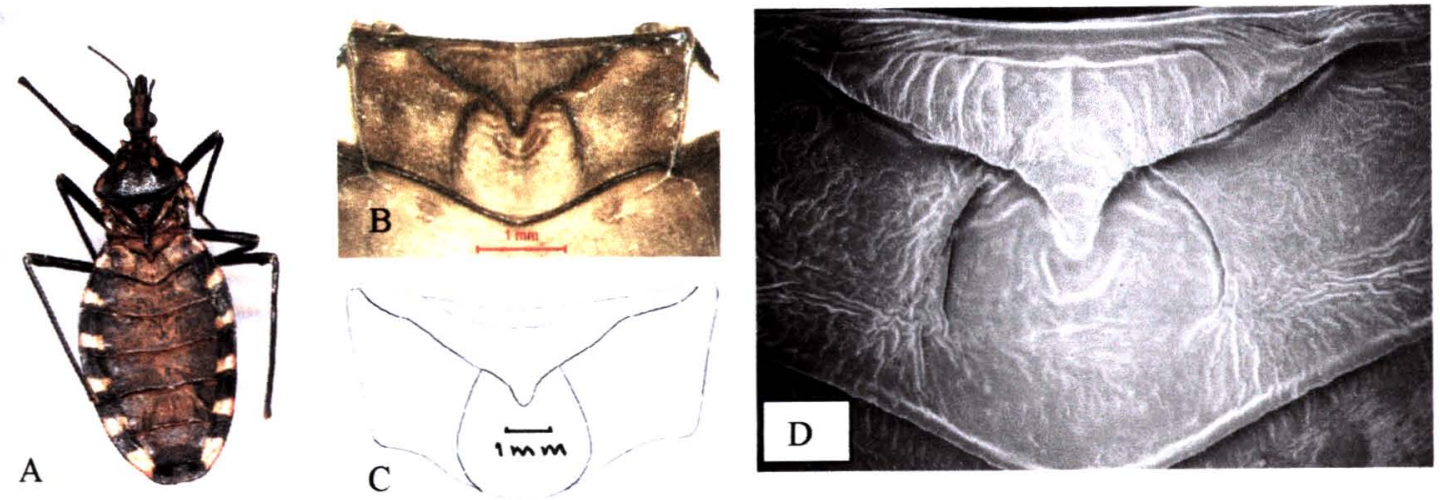

Fig. 13- Triatoma vitticeps (Stal, 1859). A. Vista dorsal do abdome do adulto macho em microscópio óptico. B. Vista dorsal do Processo do I Urotergito em microscópio digital. C. Vista dorsal do Processo do I Urotergito em câmara clara. D. Vista dorsal do Processo do I Urotergito em microscópio eletrônico de varredura (35X).

Em relação às espécies de Triatoma, observou-se que $T$. brasiliensis e $T$. sordida apresentaram o ápice do $1^{\circ}$ urotergito em forma pontiaguda, divergindo das observações de BARATA et al. (1996b), que relataram a forma do ápice destas espécies como sendo romba. Nesta pesquisa observou-se que $T$. infestans e $T$. vitticeps também apresentaram configuração pontiaguda no ápice do $1^{\circ}$ urotergito. 
Semelhante às quatro espécies anteriores, T. rubrovaria apresentou forma pontiaguda no ápice da placa do $1^{\circ}$ urotergito, como foi salientado por BARATA et al. (1996b). A forma pontiaguda no ápice do $1^{\circ}$ urotergito foi observada também na espécie $T$. pseudomaculata. A espécie $T$. tibiamaculata foi única em apresentar configuração espiralada com ponta romba no ápice do $1^{\circ}$ urotergito.

Em relação ao padrão de distribuição de cerdas no gênero Triatoma, não foi observada a presença de cerdas nas espécies $T$. brasiliensis, $T$. infestans e $T$. sordida, discordando das observações de BARATA et al. (1996b e 1998b), que mostraram a distribuição de cerdas em toda a extensão do $1^{\circ}$ urotergito, concentradas, porém, em maior número na porção mediana da placa, nas três espécies. $O$ aspecto liso, com a presença de concavidade na Área Circular, foi confirmado nessas três espécies.

A forma e a distribuição das estrias também apresentaram modalidades distintas. No $1^{\circ}$ urotergito, T. brasiliensis mostrou estrias muito discretas distribuídas irregularmente; $T$. infestans e $T$. pseudomaculata estrias suaves verticais concentradas nas bordas laterais. T. rubrovaria apresentou cerdas distribuídas na área lateral e região centro apical, enquanto $T$. vitticeps e $T$. tibiamaculata apresentaram padrão de estrias verticais acentuadas e paralelas em toda a placa.

No $2^{\circ}$ urotergito, as seis espécies analisadas $T$. infestans, $T$. pseudomaculata, T. sordida, T. rubrovaria, T. tibiamaculata e T. vitticeps, apresentaram um par de estrias verticais, paralelas e grossas delimitando a Área Circular. Só a espécie $T$. brasiliensis apresentou aspecto liso sem ornamentação.

Comparando a extensão das estrias delimitantes da Área Circular, observouse que em cinco espécies $T$. infestans, $T$. pseudomaculata, $T$. sordida, T. rubrovaria e T. vitticeps, essas estrias atingiram a região mediana do $2^{\circ}$ urotergito enquanto que em T. tibiamaculata atingiu a borda apical desse urotergito. Em T. brasiliensis a demarcação da Área Circular não foi muito evidente.

Outros tipos de estrias menos acentuados apareceram diferenciados nas sete espécies de Triatoma. T. brasiliensis apresentou estrias muito discretas distribuídas irregularmente na superficie do $2^{\circ}$ urotergito; $T$. infestans apresentou estrias suaves concentradas nas bordas laterais semelhantes a $T$. sórdida, conforme expressado por BARATA et al. (1996b) e ainda essa última espécie apresentou estrias horizontais ligadas ao extremo apical das estrias grossas que delimitam a Área Circular e, assim, 
configuraram um arco com a concavidade voltada para o ápice do $1^{\circ}$ urotergito. $T$. pseudomaculata mostrou estrias leves verticais e horizontais espalhadas pelas áreas laterais e pela área apical do $2^{\circ}$ urotergito; T. rubrovaria apresentou estrias paralelas em toda a extensão da placa, como em $T$. infestans e $T$. sordida, conforme mostrado por BARATA et al. (1996b, 1998b); T. tibiamaculata apresentou padrão de estrias menores verticais e horizontais semelhantes a tecido de renda, enquanto que $T$. vitticeps mostrou estriação vertical na região lateral próxima do $1^{\circ}$ urotergito e horizontais na porção apical das áreas laterais.

A característica observada nas espécies $T$. brasiliensis, $T$. infestans e $T$. sordida de apresentar o ápice da placa triangular com declive pronunciado como destacado por BARATA et al. (1998b), foi observado de maneira semelhante nas espécies $T$. tibiamaculata e $T$. vitticeps e com menor intensidade nas espécies $T$. pseudomaculata e T. rubrovaria.

A forma apresentada pela Área Circular variou nas sete espécies do gênero Triatoma estudadas. Assim, T. brasiliensis apresentou configuração em ferradura; $T$. rubrovaria e $T$. vitticeps mostraram forma oval; $T$. infestans mostrou configuração semicircular, enquanto que $T$. pseudomaculata, $T$. sordida e $T$. tibiamaculata apresentaram configurações arredondada, de feijão e coração, respectivamente.

Quando comparado o Processo do I Urotergito dos gêneros Panstrongylus, Rhodnius e Triatoma, Observaram-se diferentes padrões de acordo com a região analisada.

A placa do $1^{\circ}$ urotergito do gênero Panstrongylus e Triatoma apresenta forma triangular ou trapezoidal, enquanto que o gênero Rhodnius apresenta forma triangular. Em vista dorsal a placa do $1^{\circ}$ urotergito aparece em um plano mais elevado em relação à placa do $2^{\circ}$ urotergito nos gêneros Panstrongylus e Triatoma mas no gênero Rhodnius as duas placas estão localizadas quase no mesmo nível. Em relação ao ápice do $1^{\circ}$ urotergito observa-se a configuração romba no gênero Panstrongylus, romba ou pontiaguda no gênero Rhodnius e romba, pontiaguda ou espiralada no gênero Triatoma.

$O$ padrão de estriação do $1^{\circ}$ urotergito é também diferenciado. No gênero Panstrongylus aparece coberto por perceptíveis estrias verticais paralelas de aspecto 
rugoso e ramificado, o gênero Rhodnius apresenta estrias verticais lisas ou rugosas e ramificadas com discreto paralelismo lateral em toda a superfície e o gênero Triatoma apresenta estrias verticais paralelas concentradas nas bordas laterais e na região centro apical.

Quando comparadas as configurações do $2^{\circ}$ urotergito, observa-se que o gênero Panstrongylus apresenta estrias horizontais paralelas e lisas ou com discreta rugosidade distribuídas nas regiões laterais da Área Circular; o gênero Rhodnius apresenta nessa placa de 5 a 11 estrias verticais paralelas, lisas ou rugosas, simples ou ramificadas, concêntricas ou não em continuidade com a arquitetura do $1^{\circ}$ urotergito apresentando o resto da placa com aspecto glabro sem ornamentação definida; o gênero Triatoma apresenta nessa placa estrias grossas paralelas entre si, concêntricas ou divergentes, que delimitam a Área Circular. Algumas vezes podem aparecer estrias horizontais paralelas ao ápice do $1^{\circ}$ urotergito, que se estendem em toda a placa retangular e estriação vertical ou oblíqua paralela ou não às duas estrias grossas que delimitam a Área Circular.

Dependendo do gênero, existem diferenças na configuração da Área Circular. No gênero Panstrongylus, essa região apresenta forma de ferradura sem ornamentação definida; no gênero Rhodnius apresenta forma ovóide sem ornamentação definida e no gênero Triatoma mostra diversas configurações tais como ferradura, oval, semicircular, arredondada, feijão e coração. Embora o padrão predominante em relação à demarcação da Área Circular foram duas estrias grossas no gênero Panstrongylus e Triatoma, esse padrão mudou para o gênero Rhodnius, aparecendo um conjunto de estrias verticais aparentemente do mesmo calibre, como demonstrado por BARATA et al. (1996a, 1996b, 1996c, 1998a, 1998b).

O padrão de distribuição de cerdas mostra-se também diferenciado para os três gêneros. $\mathrm{O}$ gênero Panstrongylus apresenta inúmeras cerdas distribuídas principalmente na região central do $1^{\circ}$ urotergito; o gênero Rhodnius pode apresentar diminutas cerdas distribuídas irregularmente sobre a superfície do $1^{\circ}$ urotergito e na região central da placa do $2^{\circ}$ urotergito; no gênero Triatoma podem aparecer algumas cerdas curtas ou longas, distribuidas principalmente na região central da placa do $1^{\circ}$ urotergito sendo que algumas cerdas podem aparecer esparsas por toda a placa retangular. 


\subsection{Estudo morfométrico do Processo do I Urotergito}

\subsubsection{Dispersão e confiabilidade das distribuições por atributo}

A Tabela 2 mostra as 360 medidas morfométricas observadas nas 12 amostras de triatomíneos considerando os seis atributos estudados. Na tabela 3 apresentam-se as estatísticas descritivas, ressaltando-se na ultima coluna os resultados obtidos para os Coeficientes de Variação em cada colônia.

Esses coeficientes calculados para cada uma das colônias com base na razão entre o desvio padrão e a média de cada um dos atributos taxonômicos mostram que os valores dos atributos são inferiores a $20 \%$, valor limite para a indicação da confiabilidade dos resultados a serem obtidos em analises morfométricas (DUJARDIN 1999a).

Entretanto, vale ressaltar a inexistência de um padrão de dispersão nas 72 distribuições consideradas no estudo, bem como a consistência observada em todos os atributos para a amostra da espécie TVIT, cujos resultados são inferiores a $10 \%$. Nota-se ainda, possível instabilidade (valores maiores que $10 \%$ ) nos resultados de todos os atributos nas amostras das espécies TBRAS, TPSDM e TRUB, bem como para os atributos CU1 e CU2 nas amostras das colônias PM145 e PM151, e para o LMAC nas espécies RNA, RNE, RPRO, TINF e TSOR.

$\mathrm{Na}$ Tabela 4 apresentam-se os Coeficientes de Correlação (CC) para o conjunto de medidas dos seis atributos taxonômicos analisados nas 12 colônias de triatomíneos.

Conforme o CC que varia entre -1 a +1 , foi determinado o grau de associação entre os seis atributos.

Os valores registrados entre os atributos para uma mesma colônia, confirmaram a indicação de inexistência de padrão para a variabilidade simultânea entre atributos. Repetiu-se ainda a consistência verificada para a amostra da espécie TVIT, cujos Coeficientes de Correlação foram superiores a $68 \%$, e a instabilidade dos resultados verificados para os atributos CU1 e CU2 nas amostras das colônias PM145 e PM151, com resultados discordantes e a maioria abaixo de $60 \%$.

Com base nos resultados anteriores, pode-se afirmar que os atributos LMAC, CU1 e CU2 foram mais variáveis que os atributos LBU1, LBU2 e LAU2. 
Estes achados sugerem que em próximas pesquisas morfométricas do PIU, poderiam adotar-se esses três últimos atributos que apresentaram menos instabilidade para serem trabalhados mais detalhadamente com espécies triatomíneas de difícil identificação. 
Tabela 2- Medidas morfométricas em milímetros de seis atributos estudados nas colônias Panstrongylus megistus 145 (PM145), P. megistus 151 (PM151), Rhodnius nasutus (RNA), $R$. neglectus (RNE), $R$. prolixus (RPRO), Triatoma brasiliensis (TBRAS), T. infestans (TINF), T. pseudomaculata(TPSDM), T. rubrovaria (TRUB), $T$. sordida (TSOR), T. tibiamaculata (TTIB) e T. vitticeps (TVIT).

\begin{tabular}{|c|c|c|c|c|c|c|c|c|c|c|c|c|c|}
\hline & & PM145 & PM151 & $\overline{\mathrm{RNA}}$ & RNE & RPRO & TBRAS & TINF & TPSDM & TRUB & TSOR & TTIB & TVIT \\
\hline \multirow{30}{*}{$\frac{8}{\frac{8}{2}}$} & \multirow{5}{*}{$\underset{2}{2}$} & 6.91 & 7.11 & 3.51 & 3.90 & 3.38 & 3.72 & 4.05 & 3.68 & 2.64 & 3.50 & 7.75 & 7.25 \\
\hline & & 6.64 & 6.47 & 3.53 & 4.18 & 3.80 & 2.85 & 4.62 & 3.35 & 3.65 & 3.41 & 5.96 & 7.67 \\
\hline & & 7.46 & 6.18 & 3.19 & 4.21 & 4.27 & 2.78 & 4.67 & 3.21 & 2.97 & 3.40 & 6.17 & 7.58 \\
\hline & & 7.30 & 6.89 & 3.10 & 3.92 & 3.68 & 2.51 & 4.69 & 2.81 & 2.81 & 3.15 & 6.31 & 7.92 \\
\hline & & 6.33 & 7.09 & 3.12 & 4.04 & 4.16 & 3.00 & 4.33 & 2.98 & 2.91 & 3.34 & 6.83 & 7.00 \\
\hline & \multirow{5}{*}{ 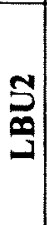 } & 7.79 & 7.78 & 4.16 & 4.50 & 4.30 & 4.45 & 4.79 & 4.67 & 2.93 & 3.81 & 8.02 & 8.02 \\
\hline & & 7.59 & 7.15 & 4.18 & 5.17 & 4.72 & 3.64 & 5.38 & 4.02 & 3.86 & 3.84 & 7.02 & 8.31 \\
\hline & & 8.11 & 6.83 & 4.00 & 4.96 & 4.91 & 3.63 & 5.19 & 3.90 & 3.24 & 3.97 & 6.86 & 8.35 \\
\hline & & 8.00 & 7.52 & 3.73 & 4.69 & 4.61 & 3.46 & 5.27 & 3.72 & 3.03 & 3.77 & 7.27 & 8.56 \\
\hline & & 7.26 & 7.50 & 4.15 & 4.91 & 4.95 & 3.58 & 5.43 & 3.70 & 3.24 & 3.88 & 7.36 & 7.48 \\
\hline & \multirow{5}{*}{$\sum_{2}^{U}$} & 2.33 & 2.10 & 0.35 & 0.50 & 0.40 & 1.18 & 1.36 & 1.64 & 1.19 & 1.27 & 2.54 & 2.67 \\
\hline & & 2.06 & 2.26 & 0.37 & 0.41 & 0.41 & 0.90 & 1.75 & 1.55 & 1.14 & 1.56 & 2.11 & 3.25 \\
\hline & & 2.43 & 2.10 & 0.29 & 0.43 & 0.45 & 1.00 & 1.86 & 1.39 & 1.29 & 1.24 & 2.00 & 3.17 \\
\hline & & 2.25 & 2.24 & 0.27 & 0.44 & 0.41 & 0.96 & 1.58 & 1.17 & 1.19 & 1.37 & 2.35 & 3.21 \\
\hline & & 1.90 & 2.08 & 0.35 & 0.43 & 0.46 & 0.96 & 1.90 & 1.25 & 1.25 & 1.44 & 2.13 & 2.81 \\
\hline & \multirow{5}{*}{$\underset{\Omega}{S}$} & 6.27 & 6.55 & 3.97 & 4.67 & 4.11 & 4.08 & 4.30 & 3.99 & 2.63 & 3.18 & 7.00 & 6.98 \\
\hline & & 6.25 & 5.70 & 3.99 & 4.98 & 4.63 & 3.35 & 4.51 & 2.97 & 3.30 & 2.98 & 5.76 & 7.29 \\
\hline & & 6.69 & 5.19 & 3.75 & 4.86 & 4.71 & 3.21 & 4.39 & 3.24 & 2.80 & 3.18 & 5.75 & 7.04 \\
\hline & & 6.79 & 6.41 & 3.55 & 4.25 & 4.51 & 3.20 & 4.37 & 2.85 & 2.82 & 3.11 & 5.96 & 7.52 \\
\hline & & 5.70 & 6.30 & 3.80 & 4.90 & 4.87 & 3.11 & 4.52 & 3.01 & 2.65 & 3.05 & 5.76 & 6.42 \\
\hline & \multirow{5}{*}{$\overline{\mathrm{U}}$} & 1.67 & 1.50 & 0.98 & 1.01 & 0.90 & 1.15 & 1.12 & 1.19 & 0.64 & 0.94 & 1.78 & 1.94 \\
\hline & & 1.86 & 1.64 & 1.00 & 1.20 & 1.14 & 1.05 & 1.14 & 1.14 & 0.86 & 1.00 & 1.42 & 2.15 \\
\hline & & 1.78 & 1.13 & 0.83 & 1.00 & 1.06 & 0.92 & 1.29 & 0.93 & 0.84 & 0.92 & 1.36 & 1.96 \\
\hline & & 1.68 & 1.78 & 0.75 & 1.02 & 1.16 & 0.84 & 1.02 & 0.97 & 0.69 & 0.91 & 1.61 & 2.27 \\
\hline & & 1.41 & 1.74 & 0.82 & 1.07 & 1.05 & 0.95 & 0.99 & 1.00 & 0.68 & 0.87 & 1.42 & 1.90 \\
\hline & \multirow{5}{*}{ 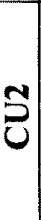 } & 3.67 & 3.35 & 2.08 & 2.18 & 1.99 & 1.95 & 2.14 & 2.28 & 1.30 & 1.74 & 3.97 & 3.94 \\
\hline & & 3.82 & 2.85 & 2.10 & 2.45 & 2.19 & 1.81 & 2.41 & 1.86 & 1.69 & 1.72 & 3.29 & 4.02 \\
\hline & & 3.54 & 2.71 & 1.87 & 2.19 & 2.27 & 1.64 & 2.51 & 1.77 & 1.52 & 1.69 & 3.19 & 3.96 \\
\hline & & 3.78 & 3.40 & 1.73 & 2.08 & 2.30 & 1.64 & 2.27 & 1.77 & 1.38 & 1.68 & 3.56 & 4.33 \\
\hline & & 2.93 & 3.50 & 1.86 & 2.37 & 2.19 & 1.60 & 2.47 & 1.79 & 1.36 & 1.61 & 3.34 & 3.67 \\
\hline
\end{tabular}

LBU1:Largura Basal do $1^{\circ}$ Urotergito; LBU2: Largura Basal do $2^{\circ}$ Urotergito; LMAC: Largura Maior da Área Circular, LAU2: Largura Apical do $2^{\circ}$ Urotergito; CU1: Comprimento do $1^{\circ}$ Urotergito; CU2: Comprimento do $2^{\circ}$ Urotergito 
Tabela 3- Estatísticas Descritivas para o Conjunto de medidas nas colônias Panstrongylus megistus 145 (PM145), P. megistus 151 (PM151), Rhodnius nasutus (RNA), $R$. neglectus (RNE), $R$ prolixus (RPRO), Triatoma brasiliensis (TBRAS), $T$. infestans (TINF), $T$. pseudomaculata(TPSDM), $T$. rubrovaria (TRUB), T. sordida (TSOR), T. tibiamaculata (TTIB) e T. vitticeps (TVIT).

\begin{tabular}{|c|c|c|c|c|c|c|}
\hline \multicolumn{7}{|c|}{ PM 145} \\
\hline ATRIB & Obs & Total & Mean & Variance & Std Dev & Coef. Var \\
\hline LBU1 & 5 & 35 & 6.920 & 0.242 & 0.492 & 7.11 \\
\hline LBU2 & 5 & 39 & 7.760 & 0.103 & 0.321 & 4.14 \\
\hline LMAC & 5 & 11 & 2.200 & 0.040 & 0.200 & 9.09 \\
\hline LAU2 & 5 & 32 & 6.360 & 0.188 & 0.434 & 6.82 \\
\hline $\mathrm{CU1}$ & 5 & 9 & 1.700 & 0.035 & 0.187 & 11.00 \\
\hline $\mathrm{CU} 2$ & 5 & 18 & 3.540 & 0.143 & 0.378 & 10.68 \\
\hline \multicolumn{7}{|c|}{ PM 151} \\
\hline AIRIB & Obs & Total & Mean & Variance & std Dev & Coef.Var \\
\hline LBU1 & 5 & 34 & 6.760 & 0.158 & 0.397 & 5.87 \\
\hline $\mathrm{LBU} 2$ & 5 & 37 & 7.360 & 0.143 & 0.378 & 5.13 \\
\hline LMAC & 5 & 11 & 2.160 & 0.008 & 0.089 & 4.12 \\
\hline LAU2 & 5 & 30 & 6.020 & 0.307 & 0.554 & 9.20 \\
\hline CU1 & 5 & 8 & 1.540 & 0.073 & 0.270 & 17.53 \\
\hline $\mathrm{CU} 2$ & 5 & 16 & 3.180 & 0.127 & 0.356 & 11.19 \\
\hline
\end{tabular}

\begin{tabular}{lrrlcrr}
\hline \multicolumn{7}{c}{ RNA } \\
\hline ATRIB & Obs & Total & Mean & Variance & Std Dev & Coef.Var \\
LBU1 & 5 & 20 & 4.060 & 0.048 & 0.219 & 5.39 \\
LBU2 & 5 & 16 & 3.280 & 0.042 & 0.205 & 6.25 \\
LMAC & 5 & 2 & 0.320 & 0.002 & 0.045 & 14.06 \\
LAU2 & 5 & 19 & 3.820 & 0.042 & 0.205 & 5.36 \\
CU1 & 5 & 4 & 0.880 & 0.012 & 0.110 & 12.50 \\
CU2 & 5 & 10 & 1.940 & 0.028 & 0.167 & 8.60 \\
\hline
\end{tabular}

\begin{tabular}{lrrrrrr}
\hline \multicolumn{7}{c}{ RNE } \\
\hline ATRIB & Obs & Total & Mean & Variance & Std Dev & Coef.Var \\
LBU1 & 5 & 24 & 4.860 & 0.073 & 0.270 & 5.55 \\
LBU2 & 5 & 20 & 4.040 & 0.023 & 0.152 & 3.76 \\
LMAC & 5 & 2 & 0.420 & 0.002 & 0.045 & 10.70 \\
LAU2 & 5 & 24 & 4.760 & 0.078 & 0.279 & 5.86 \\
CU1 & 5 & 5 & 1.060 & 0.008 & 0.089 & 8.39 \\
CU2 & 5 & 11 & 2.280 & 0.027 & 0.164 & 7.19 \\
\hline
\end{tabular}

\begin{tabular}{lrrlcrr}
\hline \multicolumn{7}{c}{ RPRO } \\
\hline ATRIB & Obs & Total & Mean & Variance & Std Dev & Coef.Var \\
LBU1 & 5 & 24 & 4.700 & 0.075 & 0.274 & 5.82 \\
LBU2 & 5 & 19 & 3.880 & 0.137 & 0.370 & 9.53 \\
LMAC & 5 & 2 & 0.440 & 0.003 & 0.055 & 12.50 \\
LAU2 & 5 & 23 & 4.560 & 0.088 & 0.297 & 6.51 \\
CU1 & 5 & 5 & 1.060 & 0.008 & 0.089 & 8.39 \\
CU2 & 5 & 11 & 2.200 & 0.015 & 0.122 & 5.54 \\
\hline
\end{tabular}

\section{TBRAS}

\begin{tabular}{rrrcccc}
\hline ATRIB & Obs & Total & Kean & Variance & Std Dev & Coef.Var \\
LBU1 & 5 & 19 & 3.760 & 0.173 & 0.416 & 11.60 \\
LBU2 & 5 & 15 & 2.980 & 0.197 & 0.444 & 14.89 \\
LMAC & 5 & 5 & 0.980 & 0.017 & 0.130 & 13.26 \\
LAU2 & 5 & 17 & 3.400 & 0.165 & 0.406 & 11.94 \\
CU1 & 5 & 5 & 0.960 & 0.018 & 0.134 & 13.95 \\
CU2 & 5 & 9 & 1.700 & 0.020 & 0.141 & 8.29
\end{tabular}

LBU1: Largura Basal do $1^{0}$ Urotergito, LBU2: Largura Basal do $2^{0}$ Urotergito, CAC: Largura Maior da Área Circular, LAU2: Largura Apical do $2^{\circ}$ Urotergito, CU1: Comprimento do $1^{\circ}$ Urotergito, CU2: Comprimento do $2^{\circ}$ Urotergito.

Continua 
Continuação Tabela 3

Estatisticas Descritivas para o Conjunto de medidas nas colônias Panstrongylus megistus 145 (PM145), P. megistus 151 (PM151), Rhodnius nasutus (RNA), $R$ neglectus (RNE), $R$. prolixus (RPRO), Triatoma brasiliensis (TBRAS), T. infestans (TINF), $T$. pseudomaculata (TPSDM), $T$. rubrovaria (TRUB), T. sordida (TSOR), T. tibiamaculata (TTIB) e $T$. vitticeps (TVIT).

\section{TINF}

\begin{tabular}{lrrrrrr}
\hline ATRIB & Obs & TOtal & Mean & Variance & Std Dev & Coef.Var \\
LBU1 & 5 & 26 & 5.220 & 0.062 & 0.249 & 4.20 \\
LBU2 & 5 & 22 & 4.460 & 0.093 & 0.305 & 6.83 \\
LMAC & 5 & 9 & 1.720 & 0.047 & 0.217 & 12.61 \\
LAU2 & 5 & 22 & 4.420 & 0.007 & 0.084 & 1.90 \\
CU1 & 5 & 6 & 1.100 & 0.015 & 0.122 & 11.09 \\
CU2 & 5 & 12 & 2.360 & 0.028 & 0.167 & 7.07 \\
\hline
\end{tabular}

\section{TPSDM}

\begin{tabular}{lrrrrrc}
\hline ATRIB & Obs & Total & Mean & Variance & Std Dev & Coef.Var \\
LBU1 & 5 & 20 & 4.000 & 0.170 & 0.412 & 10.30 \\
LBU2 & 5 & 16 & 3.220 & 0.122 & 0.349 & 10.83 \\
LMAC & 5 & 7 & 1.420 & 0.032 & 0.179 & 12.60 \\
LAU2 & 5 & 16 & 3.220 & 0.202 & 0.449 & 13.94 \\
CU1 & 5 & 5 & 1.040 & 0.013 & 0.114 & 10.96 \\
CU2 & 5 & 10 & 1.920 & 0.047 & 0.217 & 11.30 \\
\hline
\end{tabular}

TRUB

\begin{tabular}{lrrcrrr}
\hline ATRIB & Obs & Total & Mean & Variance & Std Dev & Coef.Var \\
LBU1 & 5 & 16 & 3.240 & 0.153 & 0.391 & 12.07 \\
LBU2 & 5 & 15 & 2.980 & 0.142 & 0.377 & 12.65 \\
LMAC & 5 & 6 & 1.220 & 0.007 & 0.084 & 6.88 \\
LAU2 & 5 & 14 & 2.820 & 0.082 & 0.286 & 10.14 \\
CU1 & 5 & 4 & 0.720 & 0.007 & 0.084 & 11.67 \\
CU2 & 5 & 7 & 1.460 & 0.023 & 0.152 & 10.41 \\
\hline
\end{tabular}

\section{TSOR}

\begin{tabular}{lrrrrrr}
\hline ATRIB & Obs & Total & Maan & Variance & Std Dev & Coef.Var \\
LBU1 & 5 & 19 & 3.860 & 0.008 & 0.089 & 2.30 \\
LBU2 & 5 & 17 & 3.340 & 0.023 & 0.152 & 4.55 \\
LMAC & 5 & 7 & 1.380 & 0.022 & 0.148 & 10.72 \\
LAU2 & 5 & 16 & 3.100 & 0.010 & 0.100 & 3.22 \\
CU1 & 5 & 5 & 0.920 & 0.002 & 0.045 & 4.89 \\
CU2 & 5 & 8 & 1.680 & 0.002 & 0.045 & 2.68 \\
\hline
\end{tabular}

TTIB

\begin{tabular}{lrrrrrr}
\hline ATRIB & Obs & Total & Kean & Variance & Std Dev & Coef.Var \\
LBU1 & 5 & 33 & 6.620 & 0.522 & 0.722 & 10.90 \\
LBU2 & 5 & 37 & 7.320 & 0.187 & 0.432 & 5.90 \\
LMAC & 5 & 11 & 2.220 & 0.047 & 0.217 & 9.77 \\
LAU2 & 5 & 30 & 6.080 & 0.272 & 0.522 & 8.58 \\
CU1 & 5 & 8 & 1.520 & 0.032 & 0.179 & 11.77 \\
CU2 & 5 & 17 & 3.480 & 0.107 & 0.327 & 9.39
\end{tabular}

\section{TVIT}

\begin{tabular}{lrccccc}
\hline ATRIB & Obs & Total & Mean & Variance & Std Dev & Coef.Var \\
LBU1 & 5 & 38 & 7.500 & 0.125 & 0.354 & 4.72 \\
LBU2 & 5 & 41 & 8.140 & 0.173 & 0.416 & 5.11 \\
LMAC & 5 & 15 & 3.040 & 0.073 & 0.270 & 8.88 \\
LAU2 & 5 & 35 & 7.040 & 0.173 & 0.416 & 5.91 \\
CU1 & 5 & 10 & 2.020 & 0.032 & 0.179 & 8.86 \\
CU2 & 5 & 20 & 3.980 & 0.047 & 0.217 & 5.45
\end{tabular}

LBU1: Largura Basal do $1^{0}$ Urotergito, LBU2: Largura Basal do $2^{0}$ Urotergito, LMAC: Largura Maior da Área Circular, LAU2: Largura Apical do $2^{0}$ Urotergito, CU1: Comprimento do $1^{0}$ Urotergito, CU2: Comprimento do $2^{\circ}$ Urotergito. 
Tabela 4-Coeficiente de correlação para o conjunto de medidas dos diferentes atributos nas colônias Panstrongylus megistus 145 (PM145), P. megistus 151 (PM151), Rhodnius nasutus (RNA), $R$ neglectus (RNE), $R$. prolixus (RPRO), Triatoma brasiliensis (TBRAS), T. infestans (TINF), T. pseudomaculata (TPSDM), T. rubrovaria (TRUB), T. sordida (TSOR), T. tibiamaculata (TTIB) e $T$. vitticeps (TVIT).

\begin{tabular}{|c|c|c|c|c|c|c|}
\hline \multicolumn{7}{|c|}{ PM145 } \\
\hline & LBU1 & LBU2 & LMAC & LAU2 & CU1 & CU2 \\
\hline LBU1 & 1 & & & & & \\
\hline LBU2 & 0,989689 & 1 & & & & \\
\hline LMAC & 0,905253 & 0,934127 & 1 & & & \\
\hline LAU2 & 0,950934 & 0,961873 & 0,809857 & 1 & & \\
\hline CU1 & 0,516726 & 0,604128 & 0,535177 & 0,654699 & 1 & \\
\hline CU2 & 0,551691 & 0,650364 & 0,560076 & 0,74102 & 0,868875 & 1 \\
\hline \multicolumn{7}{|c|}{ PM151 } \\
\hline & LBU1 & LBU2 & LMAC & LAU2 & CU1 & CU2 \\
\hline LBU1 & 1 & & & & & \\
\hline LBU2 & 0,963275 & 1 & & & & \\
\hline LMAC & $-0,22238$ & $-0,10072$ & 1 & & & \\
\hline LAU2 & 0,968561 & 0,985645 & $-0,02533$ & 1 & & \\
\hline CU1 & 0,682919 & 0,634437 & 0,446596 & 0,727354 & 1 & \\
\hline $\mathrm{CU} 2$ & 0,962955 & 0,891039 & $-0,1895$ & 0,937114 & 0,725101 & 1 \\
\hline \multicolumn{7}{|c|}{ RNA } \\
\hline & LBU1 & LBU2 & LMAC & LAU2 & CU1 & $\mathrm{CU} 2$ \\
\hline LBU1 & 1 & & & & & \\
\hline LBU2 & 0,646055 & 1 & & & & \\
\hline LMAC & 0,927145 & 0,704734 & 1 & & & \\
\hline LAU2 & 0,926278 & 0,885797 & 0,905712 & 1 & & \\
\hline CU1 & 0,7831 & 0,980044 & 0,812134 & 0,959411 & 1 & \\
\hline $\mathrm{CU} 2$ & 0,82246 & 0,964631 & 0,83047 & 0,976124 & 0,997262 & 1 \\
\hline \multicolumn{7}{|c|}{ RNE } \\
\hline & LBU1 & LBU2 & LMAC & LAU2 & CU1 & $\mathrm{CU} 2$ \\
\hline LBU1 & 1 & & & & & \\
\hline LBU2 & 0,892892 & 1 & & & & \\
\hline LMAC & $-0,91412$ & $-0,73508$ & 1 & & & \\
\hline LAU2 & 0,670428 & 0,734188 & $-0,35279$ & 1 & & \\
\hline CU1 & 0,734266 & 0,447253 & $-0,59167$ & 0,527661 & 1 & \\
\hline CU2 & 0,744916 & 0,551174 & $-0,52321$ & 0,837325 & 0,859746 & 1 \\
\hline
\end{tabular}

LBU1: Largura Basal do $1^{0}$ Urotergito, LBU2: Largura Basal do $2^{0}$ Urotergito, LMAC: Largura Maior da Área Circular, LAU2: Largura Apical do $2^{\circ}$ Urotergito, CU1: Comprimento do $1^{0}$ Urotergito, CU2: Comprimento do $2^{0}$ Urotergito.

Continua 


\section{Continuação Tabela 4}

Coeficiente de correlação para o conjunto de medidas dos diferentes atributos nas colônias Panstrongylus megistus 145 (PM145), P. megistus 151 (PM151), Rhodnius nasutus (RNA), R. neglectus (RNE), R. prolixus (RPRO), Triatoma brasiliensis (TBRAS), T. infestans (TINF), T. pseudomaculata (TPSDM), T. rubrovaria (TRUB), T. sordida (TSOR), T. tibiamaculata (TTIB) e T. vitticeps (TVIT).

\begin{tabular}{|c|c|c|c|c|c|c|}
\hline \multicolumn{7}{|c|}{ RPRO } \\
\hline & LBU1 & LBU2 & LMAC & LAU2 & CU1 & $\mathrm{CU} 2$ \\
\hline LBU1 & 1 & & & & & \\
\hline LBU2 & 0,969055 & 1 & & & & \\
\hline LMAC & 0,88422 & 0,929112 & 1 & & & \\
\hline LAU2 & 0,981488 & 0,904555 & 0,824215 & 1 & & \\
\hline CU1 & 0,503026 & 0,34343 & 0,084801 & 0,590776 & 1 & \\
\hline $\mathrm{CU} 2$ & 0,684994 & 0,62227 & 0,410175 & 0,696859 & 0,867219 & 1 \\
\hline \multicolumn{7}{|c|}{ TBRAS } \\
\hline & LBU1 & LBU2 & LMAC & LAU2 & CU1 & CU2 \\
\hline LBU1 & 1 & & & & & \\
\hline LBU2 & 0,956206 & 1 & & & & \\
\hline LMAC & 0,917229 & 0,846326 & 1 & & & \\
\hline LAU2 & 0,975543 & 0,885037 & 0,871032 & 1 & & \\
\hline CU1 & 0,860132 & 0,887441 & 0,591735 & 0,843079 & 1 & \\
\hline CU2 & 0,868285 & 0,779763 & 0,638196 & 0,931768 & 0,910268 & 1 \\
\hline \multicolumn{7}{|c|}{ TINF } \\
\hline & LBU1 & LBU2 & LMAC & LAU2 & CU1 & CU2 \\
\hline LBU1 & 1 & & & & & \\
\hline LBU2 & 0,641096 & 1 & & & & \\
\hline LMAC & 0,819857 & 0,519795 & 1 & & & \\
\hline LAU2 & 0,887328 & 0,313725 & 0,788585 & 1 & & \\
\hline CU1 & $-0,28768$ & 0,254139 & 0,131328 & $-0,25415$ & 1 & \\
\hline $\mathrm{CU} 2$ & 0,751437 & 0,558763 & 0,986046 & 0,723019 & 0,293136 & 1 \\
\hline \multicolumn{7}{|c|}{ TPSDM } \\
\hline & LBU1 & LBU2 & LMAC & LAU2 & CU1 & CU2 \\
\hline LBU1 & 1 & & & & & \\
\hline LBU2 & 0,934981 & 1 & & & & \\
\hline LMAC & 0,877392 & 0,980092 & 1 & & & \\
\hline LAU2 & 0,932352 & 0,849385 & 0,730933 & 1 & & \\
\hline CU1 & 0,811287 & 0,801811 & 0,833595 & 0,595207 & 1 & \\
\hline CU2 & 0,969332 & 0,848626 & 0,769461 & 0,92633 & 0,819596 & 1 \\
\hline
\end{tabular}

LBU1: Largura Basal do $1^{\circ}$ Urotergito, LBU2: Largura Basal do $2^{\circ}$ Urotergito, LMAC: Largura Maior da Área Circular, LAU2: Largura Apical do $2^{\circ}$ Urotergito, CU1: Comprimento do $1^{0}$ Urotergito, CU2: Comprimento do $2^{0}$ Urotergito. 


\section{Continuação Tabela 4}

Coeficiente de correlação para o conjunto de medidas dos diferentes atributos nas colônias Panstrongylus megistus 145 (PM145), P. megistus 151 (PM151), Rhodnius nasutus (RNA), $R$. neglectus (RNE), $R$. prolixus (RPRO), Triatoma brasiliensis (TBRAS), T. infestans (TINF), T. pseudomaculata(TPSDM), T. rubrovaria (TRUB), T. sordida (TSOR), T. tibiamaculata (TTIB) e T. vitticeps (TVIT).

\begin{tabular}{|c|c|c|c|c|c|c|}
\hline \multicolumn{7}{|c|}{ TRUB } \\
\hline & LBU1 & LBU2 & LMAC & LAU2 & CU1 & $\mathrm{CU} 2$ \\
\hline LBU1 & 1 & & & & & \\
\hline LBU2 & 0,993343 & 1 & & & & \\
\hline LMAC & $-0,39265$ & $-0,44766$ & 1 & & & \\
\hline LAU2 & 0,904702 & 0,947121 & $-0,60571$ & 1 & & \\
\hline CU1 & 0,795478 & 0,810051 & 0,007649 & 0,775754 & 1 & \\
\hline $\mathrm{CU} 2$ & 0,927944 & 0,947895 & $-0,28404$ & 0,928789 & 0,947853 & 1 \\
\hline \multicolumn{7}{|c|}{ TSOR } \\
\hline & LBU1 & LBU2 & LMAC & LAU2 & CU1 & CU2 \\
\hline LBU1 & 1 & & & & & \\
\hline LBU2 & 0,37362 & 1 & & & & \\
\hline LMAC & $-0,28989$ & $-0,16333$ & 1 & & & \\
\hline LAU2 & 0,20105 & 0,161928 & $-0,99504$ & 1 & & \\
\hline CU1 & $-0,16905$ & 0,397832 & 0,381496 & $-0,34044$ & 1 & \\
\hline CU2 & $-0,2543$ & 0,469991 & $-0,18711$ & 0,2506 & 0,800291 & 1 \\
\hline
\end{tabular}

TTIB

\begin{tabular}{lllllll}
\hline & LBU1 & LBU2 & LMAC & LAU2 & CU1 & CU2 \\
\hline LBU1 & 1 & & & & & \\
LBU2 & 0,953952 & 1 & & & & \\
LMAC & 0,764136 & 0,90233 & 1 & & & \\
LAU2 & 0,88204 & 0,915823 & 0,88904 & 1 & & \\
CU1 & 0,766862 & 0,892104 & 0,995186 & 0,915995 & 1 & \\
CU2 & 0,847703 & 0,944706 & 0,983969 & 0,954303 & 0,988861 & 1 \\
\hline
\end{tabular}

TVIT

\begin{tabular}{lllllll}
\hline & LBU1 & LBU2 & LMAC & LAU2 & CU1 & CU2 \\
\hline LBU1 & 1 & & & & & \\
LBU2 & 0,963121 & 1 & & & & \\
LMAC & 0,848501 & 0,750503 & 1 & & & \\
LAU2 & 0,95543 & 0,957241 & 0,689231 & 1 & & \\
CU1 & 0,88898 & 0,763456 & 0,724439 & 0,87963 & 1 & \\
CU2 & 0,931665 & 0,91068 & 0,610631 & 0,95793 & 0,893796 & 1 \\
\hline
\end{tabular}

LBU1: Largura Basal do $1^{0}$ Urotergito, LBU2: Largura Basal do $2^{\circ}$ Urotergito, LMAC: Largura Maior da Área Circular, LAU2: Largura Apical do $2^{\circ}$ Urotergito, CU1: Comprimento do $1^{0}$ Urotergito, CU2: Comprimento do $2^{0}$ Urotergito. 


\subsubsection{Comparação entre colônias}

Os resultados da análise de variância, bem como os intervalos de confiança, expressos na Tabela 5, evidenciam a possibilidade de diferenças entre as espécies para os seis, atributos estudados.

As saídas do processamento da ANOVA encontram-se detalhadas no Anexo I.

Para as colônias PM145, PM151, TTIB E TVIT as medias são regularmente maiores compondo um primeiro grupo, enquanto as demais parecem compor um segundo grupo caracterizado por medidas homogeneamente inferiores. Esse aspecto pode ser visualizado nas Figuras 14 à 19 que mostram as distribuições das medidas obtidas nas amostras de cada espécie para cada atributo.

Os resultados da analise de agrupamento, cujo diagrama apresenta-se na Figura 20, confirmam as evidências indicadas na analise descritiva. As quatro colônias PM145, PM151, TTIB E TVIT, foram reunidas no primeiro grupo a ser considerado semelhante, quando caracterizados pelos atributos estudados. As espécies TBRAS, TSPDM, TSOR,TRUB e RNA foram reunidas em um segundo grupo, separadas portanto do agrupamento composto por RNE, RPRO e TINF que são mais similares entre si.

A Tabela 6 exibe as médias das amostras para os três atributos com distribuições consideradas estáveis, permitindo verificar simultaneamente a diferença entre os grupos e a similaridade entre as espécies que compõem um mesmo grupo. 
Tabela 5- Estimativas para Média (M), Desvio Padrão (EP), Intervalos de Confiança (IC) para os atributos estudados nas espécies de triatomíneos Panstrongylus megistus 145 (PM145), P. megistus 151 (PM151), Rhodnius nasulus (RNA), R. neglectus (RNE), R. prolixus (RPRO), Triatoma brasiliensis (TBRAS), T. infestans (TINF), T. pseudomaculata (TPSDM), T. rubrovaria (TRUB), T. sordida (TSOR), $T$. tibiamaculata (TTIB) e T. vitticeps (TVIT)

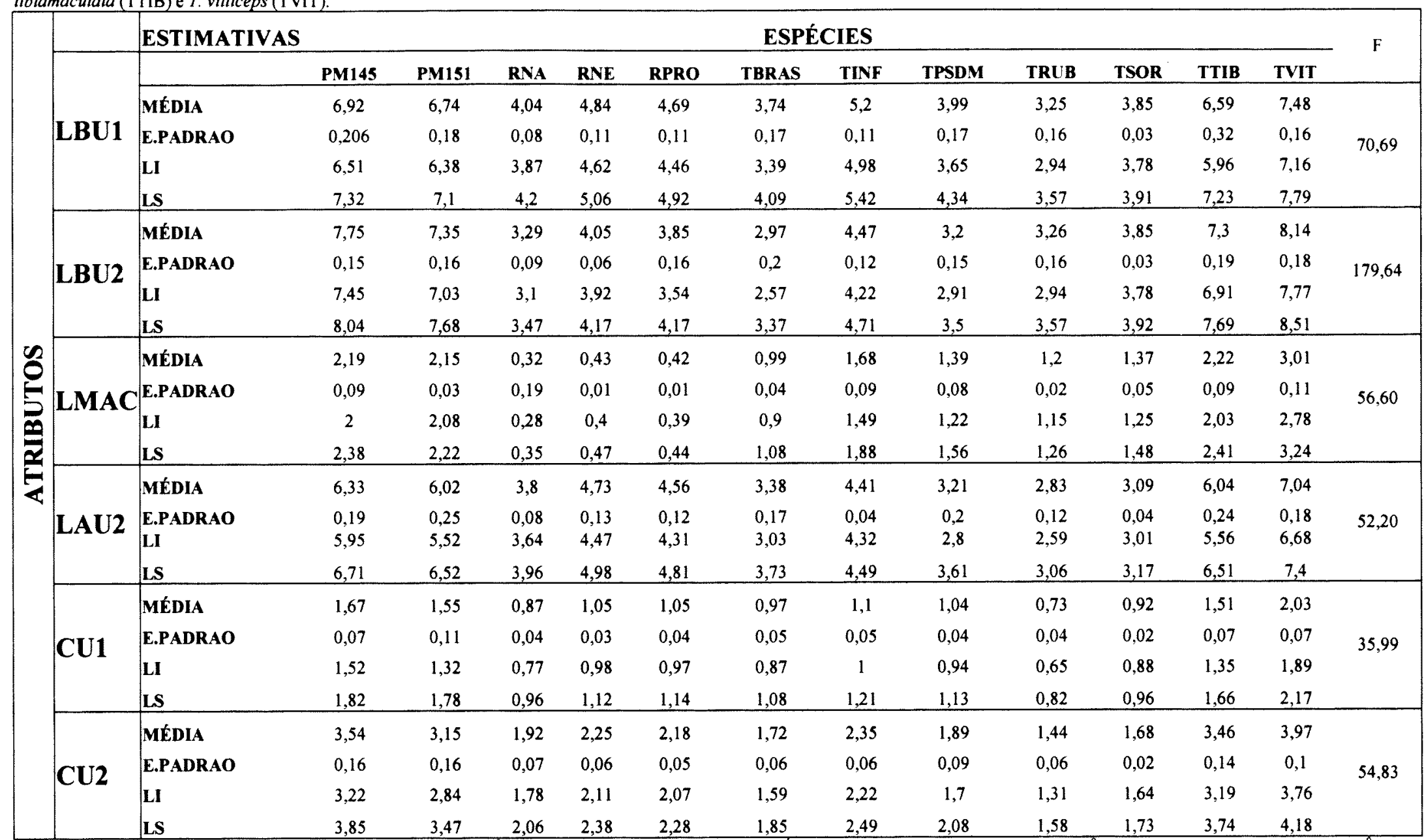

LBU1: Largura Basal do $1^{0}$ Urotergito, LBU2: Largura Basal do $2^{0}$ Urotergito, LMAC: Largura Maior da Área Circular, LAU2: Largura Apical do $2^{0}$ Urotergito, CU1: Comprimento do $1^{0}$ Urotergito, CU2: Comprimento do $2^{0}$ Urotergito.

Valor do $p=0.000$ 
Tabela 6- médias das amostras para os três atributos com distribuições consideradas estáveis nas colônias Panstrongylus megistus 145 (PM145), P. megistus 151 (PM151), Rhodnius nasutus (RNA), $R$ neglectus (RNE), $R$. prolixus (RPRO), Triatoma brasiliensis (TBRAS), T. infestans (TINF), T. pseudomaculata (TPSDM), $T$. rubrovaria (TRUB), $T$. sordida (TSOR), $T$. tibiamaculata (TTIB) e $T$. vitticeps (TVIT).

\begin{tabular}{llll}
\hline & \multicolumn{2}{l}{ Atributos } & LAU2 \\
\cline { 2 - 4 } Grupos de colônias & LBU1 & LBU2 & 6,33 \\
PM145 & 6,92 & 7,75 & 6,02 \\
PM151 & 6,74 & 7,35 & 6,04 \\
TTIB & 6,59 & 7,30 & 7,04 \\
TVIT & 7,48 & 8,14 & \\
& & & 4,73 \\
RNE & 4,05 & 4,84 & 4,56 \\
RPRO & 3,85 & 4,69 & 4,41 \\
TINF & 4,47 & $5,2,0$ & \\
& & & 3,80 \\
RNA & 3,29 & 4,04 & 3,38 \\
TBRAS & 2,97 & 3,74 & 3,21 \\
TPSDM & 3,20 & 3,99 & 3,09 \\
TSOR & 3,26 & 3,85 & 2,83 \\
TRUB & 3,85 & 3,29 & \\
\hline
\end{tabular}

LBU1: Largura Basal do $1^{\circ}$ Urotergito, LBU2: Largura Basal do $2^{0}$ Urotergito, LAU2: Largura Apical do $2^{0}$ Urotergito. 
A distribuição das medidas dos seis atributos por espécie, com base nos dados da Tabela 2, apresentam-se nas Figuras 14 a 19.

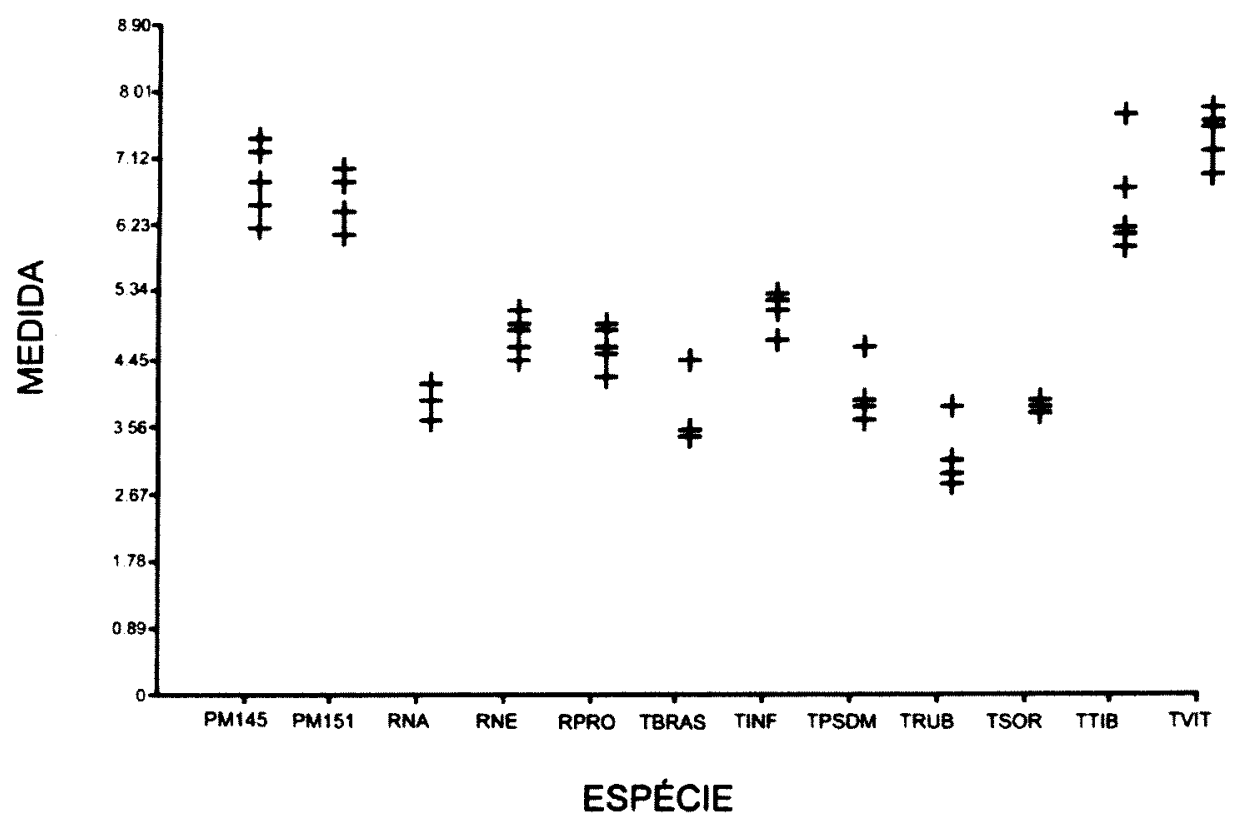

Figura 14. LBU1- Largura Basal do $1^{\circ}$ Urotergito. Distribuição das medidas em mm segundo espécie.

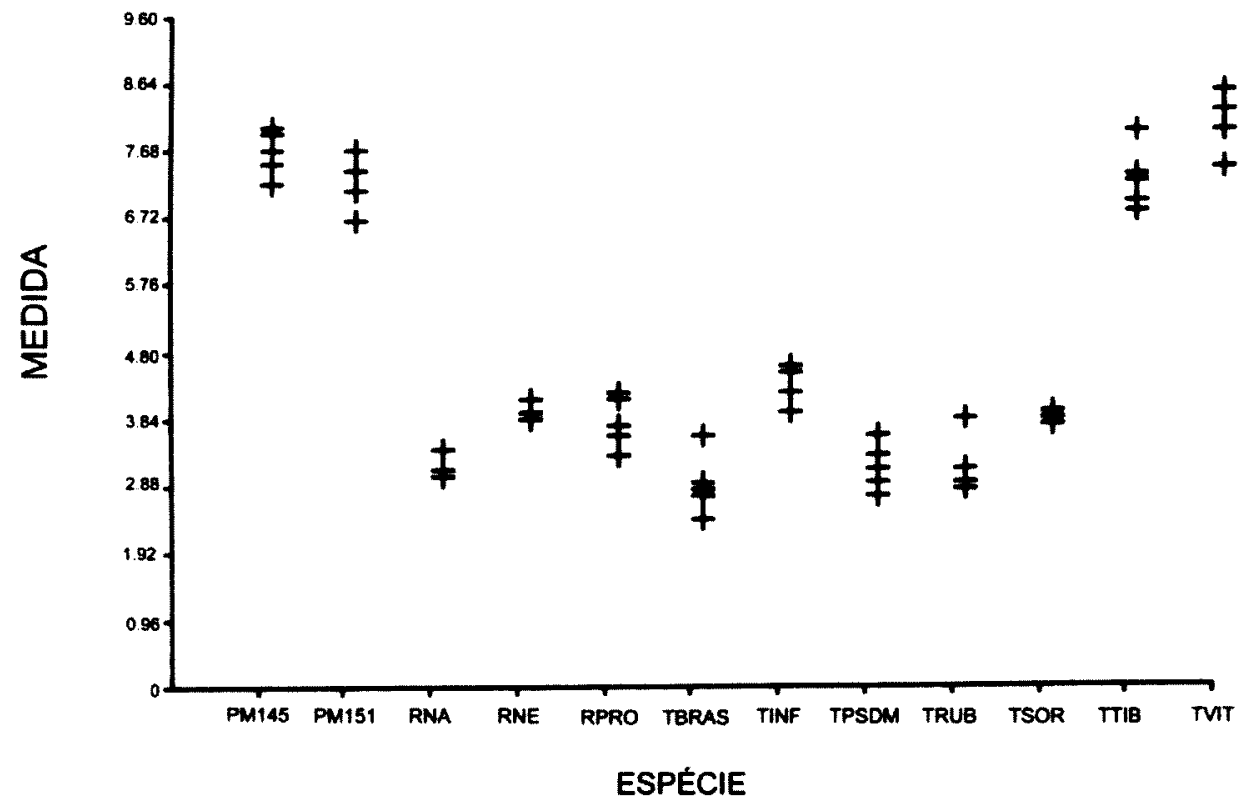

Figura 15. LBU2- Largura Basal do $2^{\circ}$ Urotergito. Distribuição das medidas em $\mathrm{mm}$ segundo espécie. 


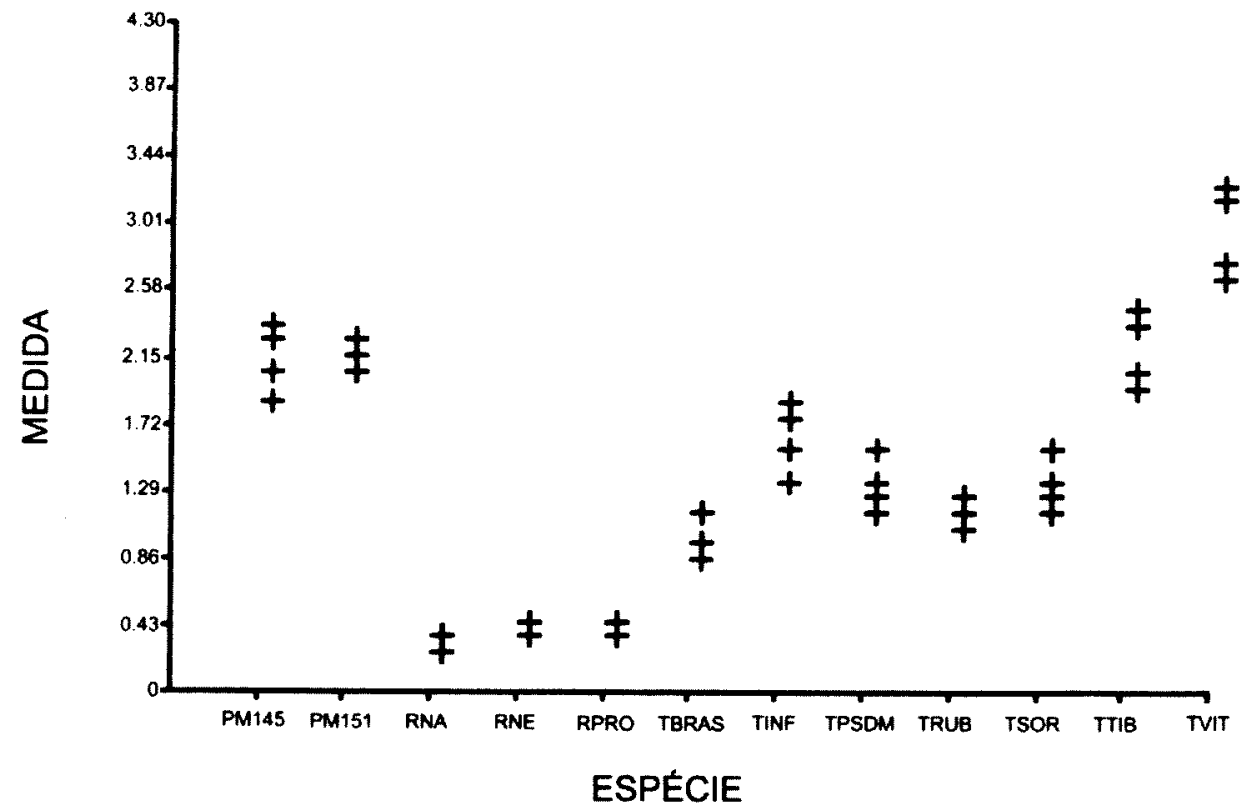

Figura 16. LMAC-Largura Maior da Área Circular. Distribuição das medidas em mm segundo espécie.

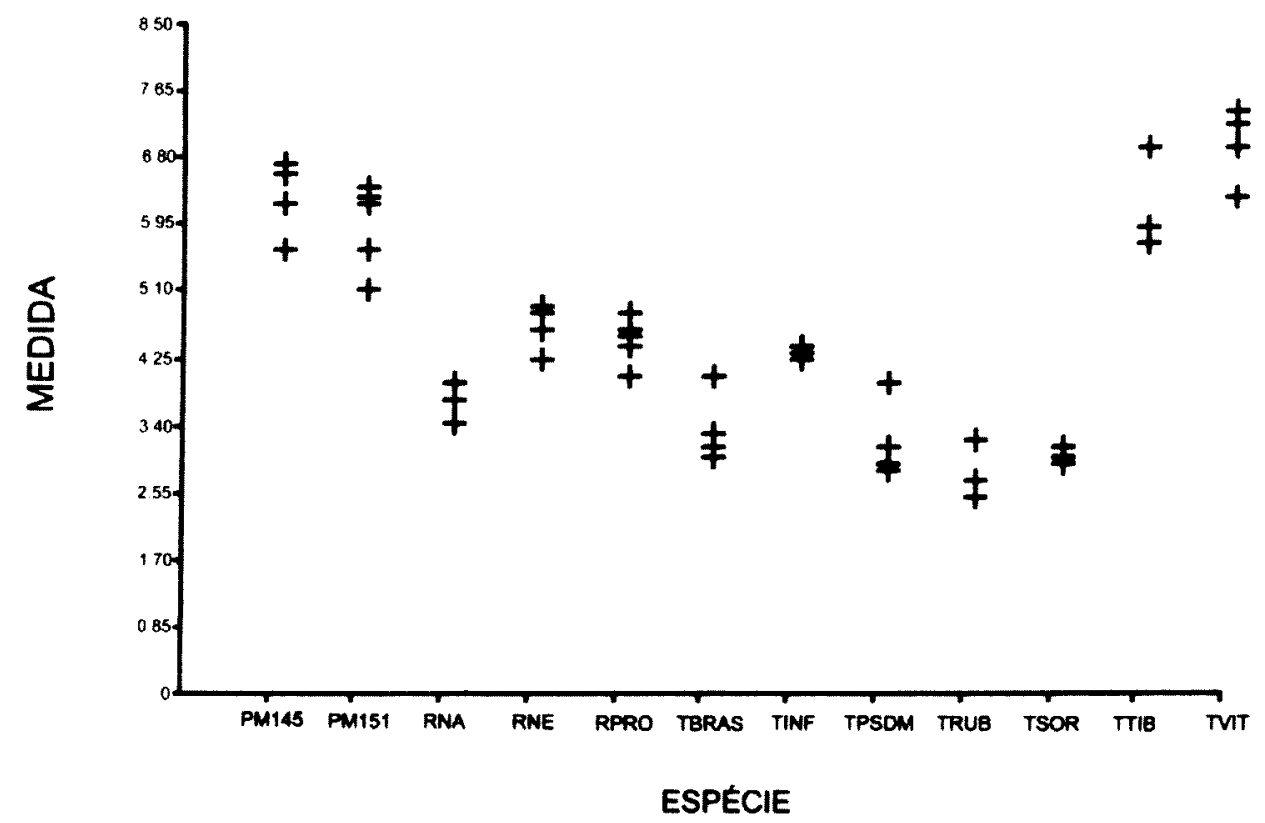

Figura 17. LAU2- Largura Apical do $2^{\circ}$ Urotergito. Distribuição das medidas em $\mathrm{mm}$ segundo espécie. 


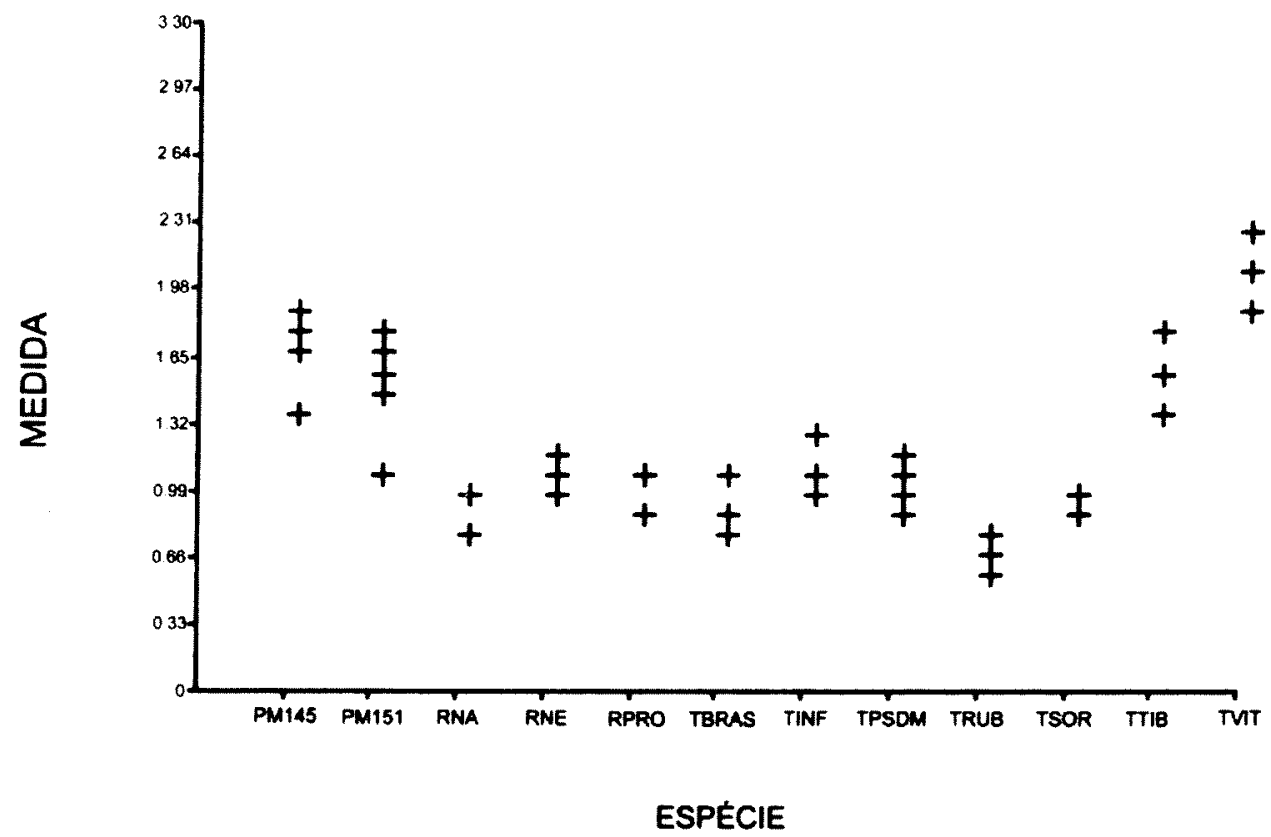

Figura 18. CUI-Comprimento do $1^{\circ}$ Urotergito. Distribuição das medidas em $\mathrm{mm}$ segundo espécie.

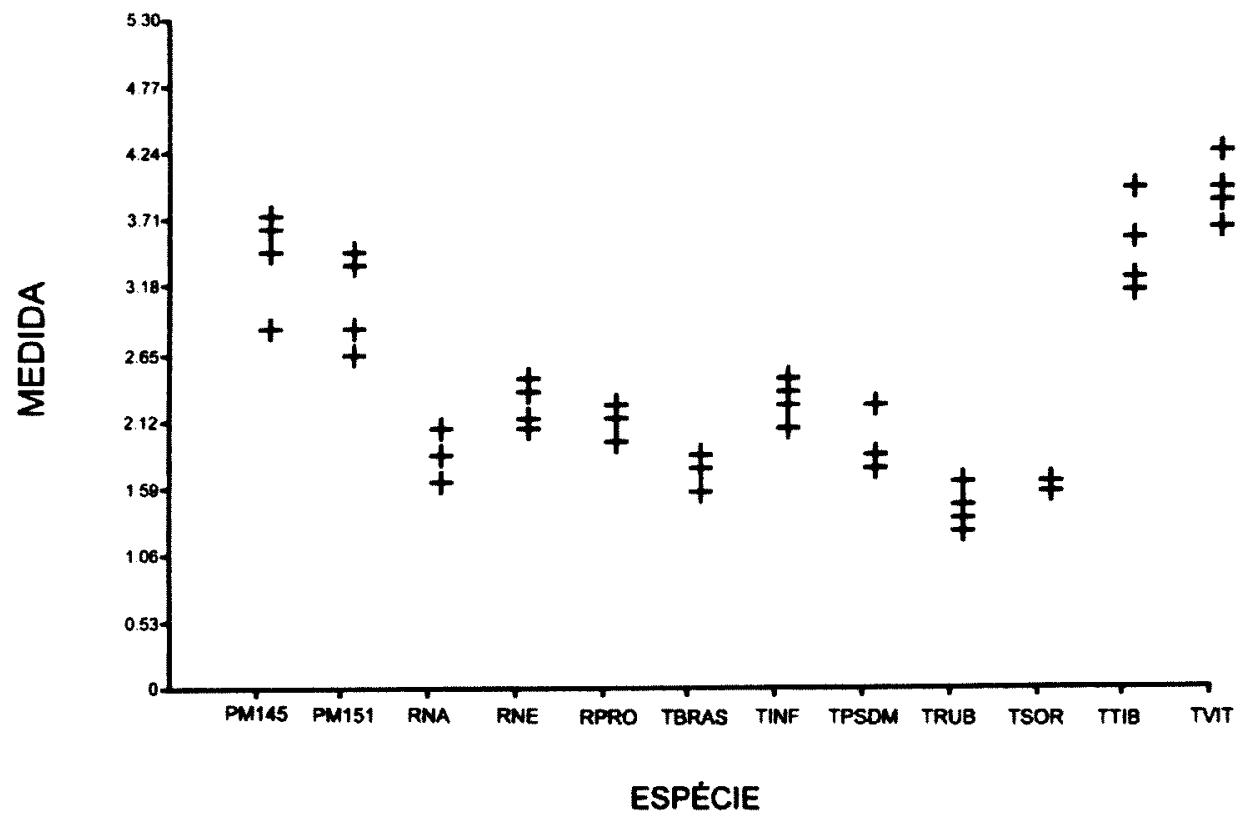

Figura 19. CU2-Comprimento do $2^{\circ}$ Urotergito. Distribuição das medidas em $\mathrm{mm}$ segundo espécie. 
Das Figs. 14 a 19 observa-se que a colônia PM 145 da espécie $P$. megistus procedente de Almino Afonso - Rio Grande do Norte, apresentou mensurações dos seis atributos ligeiramente maiores que a colônia CTA 151, procedente de Curitiba Paraná. Embora não se disponha de dados ecológicos, completos sobre essas duas colônias, supor-se-á que a PM 145 apresentaria um processo de domiciliação mais antigo que a PM 151. Nesta situação a primeira deveria apresentar medidas menores que a segunda, considerando que as populações silvestres tendem a apresentar medidas absolutas maiores que as domiciliadas, de acordo com as observações para R. prolixus ( HARRY 1994). Um outro fator que deve ser considerado é a possibilidade de a PM 151 apresentar maiores dimensões que a PM 145, com base na Lei de Bergman que diz que "os organismos da mesma espécie vivendo em ambientes mais frios são geralmente de maior tamanho" (RAY 1960), porém, também isto se mostrou ao contrário.

É provável que esses triatomíneos da colônia PM 145 ainda pertençam a uma população silvestre em processo de domiciliação, sendo que nesse caso, estariam sendo comparadas duas colônias silvestres; daí que a influência seria do fator latitudinal e térmico e não comportamental.

De acordo com as Figs. 14 a 19 em relação aos atributos taxonômicos LBU1, LBU2, LMAC, LAU2, CU1, CU2 observou-se semelhança entre os valores obtidos, para as espécies $P$. megistus (PM 145 e PM 151), T. tibiamaculata e T. vitticeps (Fig. 14).

Nos valores obtidos para as outras espécies, $R$. nasutus (RNA), $R$. neglectus (RNE), R. prolixus (RPRO), T. brasiliensis (TBRAS), T. infestans (TINF), T. pseudomaculata (TPSDM), T. rubrovaria (TRUB) e $T$. sordida (TSOR), não se observaram diferenças significativas entre as espécies.

Com base nas observações anteriores, poder-se-iam estabelecer três grupos de espécies.

O primeiro grupo seria formado pelas espécies $P$. megistus (colônias PM 145 e 151), T. tibiamaculata e $T$. vitticeps, cujos valores dos atributos taxonômicos seriam superiores a 5,34 mm para a variável LBU1 ( Fig. 14), acima de 5,76 mm. para o atributo LBU2 ( Fig. 15), acima de 2,15 mm., para o atributo LMAC ( Fig. 
16), valores superiores a 5,10 mm, para a variável LAU2 ( Fig. 17), acima de 1,32 mm, para a variável CU1 ( Fig. 18) e acima de $2,85 \mathrm{~mm}$ para a variável (CU2).

O segundo grupo seria composto pelas espécies $R$. neglectus, $R$. prolixus e $T$. infestans, cujos valores estão acima de $4,45 \mathrm{~mm}$ para o atributo LBU1 ( Fig. 14); acima de 3,84 mm para a variável LBU2 ( Fig. 15); valores superiores a 4,25 mm para o atributo LAU2 ( Fig. 17); acima de 2,12 mm para o caráter CU2 ( Fig. 19).

Nota-se neste grupo que o padrão anterior não foi estabelecido para os atributos LMAC (Fig. 16) e para CU1 (Fig. 18).

O terceiro grupo seria formado pelas espécies $R$. nasutus, $T$. brasiliensis, $T$. pseudomaculata (TPSDM), T. rubrovaria (TRUB) e T. sordida (TSOR), cujos valores morfométricos estão baixo de $4,45 \mathrm{~mm}$ para o atributo LBU1 ( Fig. 14), valores abaixo de 3,84 mm para o atributo LBU2 (Fig. 15); valores menores de 1,70 mm para o a tributo CU2 ( Fig. 19).

Da mesma forma que para o segundo grupo, o padrão não foi seguido para os atributos LMAC e CU1.

Dos resultados anteriores depreende-se que, apesar de se ter formado os três grupos de espécies, com base na similaridade de valores morfométricos, essa organização não agrupa espécies correspondentes ao mesmo gênero e portanto reúne indivíduos com características taxonômicas diferentes, particularmente dos gêneros Panstrongylus, Rhodnius e Triatoma.

Uma outra conclusão que pode ser deduzida dos resultados anteriores é a dissimilaridade apresentada pelos caracteres LMAC, CU1 e CU2 no sentido de não se encaixarem no padrão dos grupos formados pelos atributos LBU1, LBU2 e LAU2. Pode-se inferir que para posteriores estudos morfométricos, esses três caracteres não deveriam ser incluídos, considerando a grande variabilidade que eles apresentam.

A variabilidade observada nesses dois atributos foi comprovada também na análise de dispersão e confiabilidade das distribuições por atributo, utilizando os coeficientes de variação e correlação.

Considera-se um avanço no esclarecimento da taxonomia dos triatomíneos, o fato de ter padronizado pelo menos três atributos taxonômicos que poderão ser utilizados em futuras pesquisas, visando caracterizar melhor o PIU e incluí-lo como uma nova estrutura na caracterização das espécies triatomíneas. 
Os resultados da analise de agrupamento, cujo diagrama apresenta-se na Figura 20, confirmam as evidências indicadas na analise descritiva. As quatro colônias PM145, PM151, TTIB e TVIT foram reunidas no primeiro grupo a ser considerado semelhante quando caracterizados pelos atributos estudados. As espécies TBRAS, TSPDM, TSOR,TRUB e RNA foram reunidas em um segundo grupo, separadas portanto do terceiro grupo composto por RNE, RPRO e TINF que são mais similares entre si.

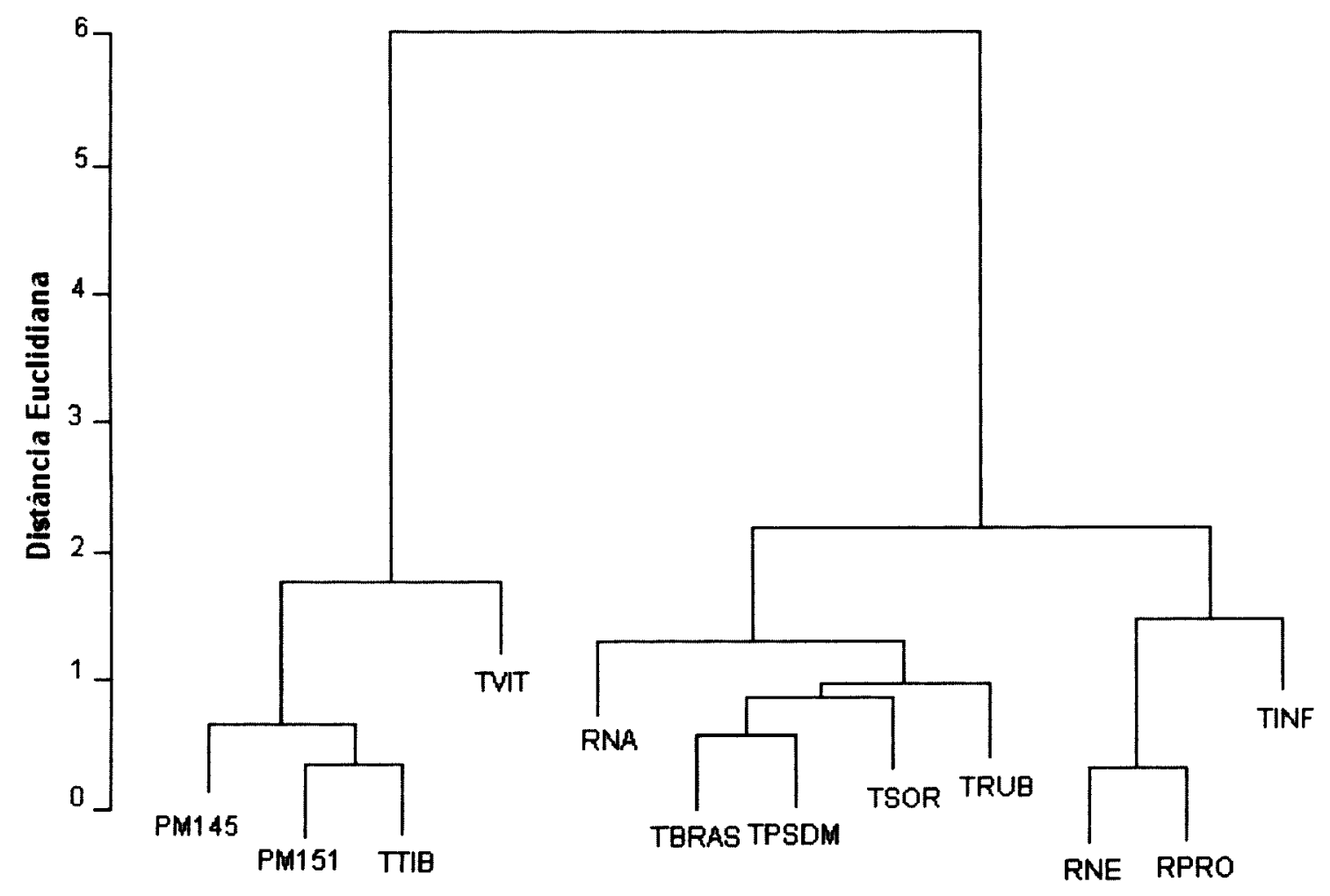

Figura 20- Valores correspondentes às medias das distâncias euclidianas entre 12 colônias de triatomíneos, considerando seis atributos.

Os resultados obtidos na análise de distribuição das medidas segundo espécies (Figs 14 a 19), na ANOVA (Tabela 5) e na análise de cluster (Fig. 20), sugerem a necessidade de aprofundamento na pesquisa sobre morfometria do PIU, utilizando um maior número de espécies de cada um dos gêneros. 


\section{CONCLUSÕES E RECOMENDACÕES}

- O Processo do 1 Urotergito é uma estrutura que pode ser utilizada na separação e identificação de espécies de triatomíneos. Não obstante deve-se aprofundar nas pesquisas desta característica, visando comparar um maior número de espécies por meio da seleção de amostras adequadas de acordo com o número descrito em cada um dos gêneros de triatomíneos.

- O estudo de atributos taxonômicos do Processo do I Urotergito, sob o ponto de vista morfométrico para separar espécies triatomíneas de difícil identificação, seria mais eficiente se realizado em conjunto com o estudo morfométrico de outras estruturas morfológicas tais como ovos, urotergitos e urosternitos de ninfas e cabeça, asas e escutelo dos adultos, entre outras.

- Os atributos taxonômicos que se mostraram mais adequados para serem utilizados na determinação do Processo do I Urotergito nas espécies triatomíneas foram "Largura Basal do $1^{\circ}$ Urotergito", "Largura Basal do $2^{\circ}$ Urotergito" e "Largura Apical do $2^{\circ}$ Urotergito".

- O atributo denominado "Largura Maior da Área Circular" não se mostrou como uma característica adequada para tipificar o Processo do l Urotergito, particularmente em relação à falta de correlação das mensurações realizadas entre as distintas espécies triatomíneas. Não obstante, salienta-se que esse atributo continua sendo útil para tipificar espécies sob o ponto de vista morfológico

- É necessário realizar mais estudos comparativos com os atributos "Comprimento do $1^{\circ}$ Urotergito" e "Comprimento do $2^{\circ}$ Urotergito" para definir a sua verdadeira utilidade como parâmetros taxonômicos, utilizando amostras maiores.

- O estudo das características morfológicas em conjunção com as características morfométricas do Processo do I Urotergito, permitiu o estabelecimento preliminar de parâmetros adequados para a inclusão dessa estrutura em futuras pesquisas taxonômicas e sistemáticas, visando a separação das espécies da subfamília Triatominae. 
- A morfometria tem-se mostrado nos últimos anos com uma ferramenta taxonômica adicional que associada com os parâmetros fálicos, isoenzimáticos, morfológicos e ecológicos contribuirão no futuro no esclarecimento da sistemática e filogenia das espécies de triatomíneos.

- No estudo das características morfológicas da nova estrutura denominada PIU, considerou-se importante tanto a utilização da microscopia óptica, desenho com câmara clara, a microscopia digital como a MEV. Cada um dos métodos forneceram elementos visuais que facilitaram uma melhor descrição dos atributos taxonômicos do Processo do I Urotergito dos triatomíneos estudados. 


\section{REFERÊNCIAS}

Albuquerque RDR, Barretto MP. Estudos sobre reservatórios silvestres do "Trypanosoma cruzi". XXX. Infecção natural de cachorro - do mato, "Cerdocyon thous azarae" (Wied, 1824) pelo “T. cruzi". Rev Bras Biol 1968; 28(4): 457-468.

Aldenderfer MS, Blashfield RK. Cluster Analysis. Beverly Hills: Sage Publications: 1986.

Barata JMS, Santos JFL, Leite CAP. Aspectos morfológicos de ovos de Triatominae. Mensuração de dez espécies do gênero Rhodnius Stal, 1859 (Hemiptera, Reduviidae). Rev Bras Entomol 1980; 24: 197-214.

Barata JMS, Santos JFL, Leite CAP. Aspectos morfológicos de ovos de Triatominae. II. Características macroscópicas e exocoriais de dez espécies do gênero Rhodnius Stal, 1859 (Hemiptera, Reduviidae). Rev Saúde Pública 1981; 15: 490- 542.

Barata JMS, Rosa JÁ da, Barata EAM, Urbinatti PR. Aspectos macroscópicos e exocoriais de ovos em oito gêneros da subfamilia Triatominae (Hemiptera, Reduviidae). IX Reunião Anual de Pesquisa Aplicada em Doença de Chagas, Uberaba, MG 1993 [Resumo]. Rev Bras Med Trop 1993; Supl 2; 95-6.

Barata JMS, Rosa JA da, Urbinatti PR, Ceretti Jr. W, Marassá AM, Barreiros RM de OV, Andrade RMG de, Serra OP. Processo do I Urotergito, nova estrutura para a identificação genérica e específica em Triatominae. In: XIV Congresso Brasileiro de Parasitologia, 1-4 de agosto de 1995 [Resumos]. Rev Patol Trop 1994a; 23 Supl 2: 216.

Barata JMS, Rosa JA da, Ceretti Jr. W, Urbinatti PR, Freitas Barata EAM de. Aspectos morfológicos de ovos em nove gêneros de Triatominae (Hemiptera, Reduviidae). Rev Patol Trop 1994b; 23 Supl 2: 217. 
Barata JMS. Aspectos morfológicos de huevos de Triatominae. Taller Internacional sobre Genética Poblacional y control de triatomíneos. Santo Domingo de los Colorados, Ecuador 24- 28 de septiembre de1995. p. 3-58.

Barata JMS, Rosa JA da, Urbinatti PR, Ceretti Jr. W, Marassá AM, Barreiros RM de OV, Andrade RMG de, Souza RP de, Mazzuia ETA. Diferenciação entre Rhodnius prolixus Stål, 1859 e Rhodnius neglectus Lent, 1954 através da utilização do Processo do I Urotergito (Hemiptera, Reduviidae). In: XXXII Congresso da SBMT, Goiânia, GO de 3-7 de março de 1996 [Resumos]. Rev Soc Bras Med Trop 1996a; 29 Supl 1: 140-141.

Barata JMS, Rosa JA da, Urbinatti PR, Ceretti Jr. W, Marassá AM, Barreiros RM de OV, Andrade RMG de, Souza RP de. Characterization of Triatoma infestans Klug, 1834 and Triatoma sordida Stål, 1859 (Hemiptera, Reduviidae) by means of the I urotergite process through scanning electron microscopy. In: XII Meeting of Brazilian Society of Protozoology, XXIII Annual Meeting on Basic Research in Chagas' Disease. Caxambu, MG, 5-8 November 1996 [Resumos]. Mem Inst Oswaldo Cruz 1996b; 91 Supl: 126.

Barata JMS, Rosa JA da, Urbinatti PR, Ceretti Jr. W, Marassá AM, Barreiros RM de OV, Andrade RMG de, Souza RP de. Characterization of Panstrongylus megistus Burmeister, 1835 and Panstrongylus herreri Wygodzinsky, 1948 (Hemiptera, Reduviidae) by means of the I urotergite process through scanning electron microscopy. In: XII Meeting of Brazilian Society of Protozoology, XXIII Annual Meeting on Basic Research in Chagas' Disease. Caxambu, MG, 5-8 November 1996 [Resumos]. Mem Inst Oswaldo Cruz 1996c; 91 Supl: 127.

Barata JMS, Rosa JA da, Urbinatti PR, Ceretti Jr. W, Andrade RMG de, Marassá AM. Characterization of the I urotergito process in Rhodnius nasutus Stal, 1859 and Rhodnius robustus Larrousse, 1927 through scanning electronic microscopy and optic microscopy. Mem Inst Oswaldo Cruz 1998a; 93 Supl: 326. 
Barata JMS, Rosa JA da, Urbinatti PR, Ceretti Jr. W, Andrade RMG de, Marassá AM. Characterization of the urotergito process in Triatoma brasiliensis Neiva, 1911 and Triatoma rubrovaria Neiva, 1913 through scanning electronic microscopy and optic microscopy. Mem Inst Oswaldo Cruz 1998b; 93 Supl: 327.

Barata JMS, Rosa JA da, Urbinatti PR, Ceretti Jr. W, Marassá AM, Barreiros RM de OV, Andrade RMG de. Characterization of the I urotergito process in Triatoma delpontei, Romanã \& Abalos, 1947 and Triatoma platensis Neiva, 1913 through electronic microscopy and optic microscopy. Mem Inst Oswaldo Cruz 1999a; 94 Supl 2: 246.

Barata JMS, Rosa JA da, Urbinatti PR, Ceretti Jr. W, Marassá AM, Barreiros RM de $\mathrm{OV}$, Andrade RMG de. Characterization of the I urotergito process in Triatoma protracta Uhler, 1894 and Triatoma lecticularia Stal, 1859 through electronic microscopy and optic microscopy. Mem Inst Oswaldo Cruz 1999b; 94 Supl 2: 246.

Barretto MP, Carvalheiro JR. Estudos sobre reservatórios silvestres do "Trypanosoma cruzi". XVIII. Observações sobre a ecologia do "Psammolestes tertius" Lent \& Jurberg, 1965 (Hemíptera, Reduviidae). Rev Bras Biol 1967; 27(1): $13-25$.

Barretto MP, Carvalheiro JR. Estudos sobre reservatórios silvestres do "Trypanosoma cruzi". XXV. Observações sobre a infestação de ninhos de "Anumbius annumbi" Vieillot, 1817 e de "Phacellodomus rufifrons rufifrons" (Wied, 1821) pelo "Psammolestes tertius" Lent \& Jurberg, 1965 (Hemíptera, Reduviidae). Rev Bras Biol 1968; 28(1): 11-17.

Barretto MP, Siqueira AF de, Ferriolli Filho F, Carvalheiro JR. Estudos sobre reservatórios silvestres do "Trypanosoma cruzi". XX. Infecção natural de ratos comensais, capturados em biótopos naturais e artificiais, por tripanossomos semelhantes ao "T. cruzi". Rev Bras Biol 1967; 27 (2): 145-156. 
Barretto MP, Siqueira AF de, Ferriolli Filho F, Carvalheiro JR, Albuquerque RDR, Funayama GK. Estudos sobre reservatórios silvestres do "Trypanosoma cruzi". XXVII. Infecção natural de quirópteros pelo "Trypanosoma vespertilionis" Bataglia, 1904. Rev Bras Biol 1968; 28(2): 147-155.

Barretto MP. Ecologia de triatomíneos e transmissão do Trypanosoma cruzi, com especial referência ao Brasil. Rev Soc Bras Med Trop 1976; 10: 339-353.

Barretto MP, Ribeiro RD, Rocha GM. Estudos sobre reservatórios silvestres do "Trypanosoma cruzi". LXIX. Inquérito preliminar sobre triatomíneos silvestres na região do triângulo mineiro, MG, Brasil. Rev Bras Biol 1978; 38(3): 633-637.

Berquó ES, Souza JMP de, Gotlieb SLD. Bioestatística. Sao Paulo: EPU; 1981.

Bussab WO, Miazaki ES, Andrade DF. Introdução à analise de agrupamentos. Nono simpósio brasileiro de probabilidade e estatística; 1990.

Cahet DMB, Carcavallo RU, Barbosa HS, Jurberg J. Estudo morfológico das asas de Triatoma jurbergi Carcavallo, Galvão \& Lent, 1998 (Hemiptera- ReduviidaeTriatominae), vistas através de Microscopia Eletrônica de Varredura (M.E.V.) e Óptica. Entomol Vect 1999; 6(3): 236- 263.

Carcavallo RU, Ravinovich JE, Tonn RJ. Factores biológicos y ecológicos en la enfermedad de Chagas. Tomo I- Epidemiologia - Vectores 1985. Número Especial Chagas 2: 20.

Carcavallo RU, Galindez- Girón I, Martínez A, Jurberg J. Cuticular structures of Triatominae. Their taxonomic significance. Entomol Vect 1994; 1(2): 79-91.

Carcavallo RU, Galindez- Girón I. Systematic value of the scutellum in Triatominae (Hemiptera, Reduviidae). Entomol Vect 1995; 2(1): 23-29. 
Carcavallo RU, Galindez- Girón I, Martínez A, Jurberg J, Lent H. Atlas of Chagas disease vectors in the Americas. Rio de Janeiro: Fiocruz; 1997. v. 3.

Carcavallo RU, Jurberg J. Triatoma baratai sp.n. do Estado do Mato Grosso do sul, Brasil (Hemiptera, Reduviidae, Triatominae). Entomol Vector 2000; 7(4): 373-387.

Carcavallo RU, Jurberg J, Lent H, Noireau F, Galvão C. Phylogeny of the Triatominae (Hemiptera: Reduviidae). Entomol Vect 2000; 7 Supl 1: 1-99.

Carcavallo RU, Jurberg J, Lent H, Galvão C, Steindel M, Pinto CJC. Nova espécie do complexo oliveriai (nova denominação para o complexo matogrossensis) (Hemiptera, Reduviidae, Triatominae) do Estado do Rio Grande do Sul, Brasil. Mem Inst Oswaldo Cruz 2001; 96(1): 77- 79.

Carcavallo RU, Jurberg J, Silva Rocha D da, Galvão C, Noireau F, Lent H. Triatoma vandae sp. n. do complexo oliverai encontrada no Estado de Mato Grosso, Brasil (Hemiptera: Reduviidae: Triatominae). Mem Inst Oswaldo Cruz 2002; 97(5): 649654.

Catalá S. Sensilla associated with the rostrum of eight species of Triatominae. J Morphol 1996; 228: 195- 201.

Catalá S. Antennal sensilla of Triatominae (Hemiptera, Reduviidae): a comparative study of five genera. Int J Insect Morphol Embriol 1997; 26(2): 67- 73.

Catalá S, Schofield CH. Antennal sensilla of Rhodnius. J Morphol 1994; 219: 193203.

$[\mathrm{CDC}]$ Centers for Disease Control and Prevention. Ecologic Niche Modeling and Potential Reservoirs for Chagas Disease, Mexico. [On line] Available from $<\mathrm{URL}$ : http://www.cdc.gov/ncidod/eid/vol8 no 7/01-0454.htm> [2002 May 26]. 
Chavez T, Moreno J, Dujardin JP. Isoenzime electrophoresesis of Rhodnius species: a phenetic approach to relationships within the genus. Ann Trop Med Parasitol 1999; 93(3): 299-307.

Corrêa AD, Siqueira- Batista R. Histórico. In: Siqueira- Batista R, Corrêa AD, Huggins DW. Moléstia de Chagas. Rio de Janeiro: Cultura Médica; 1996. p. 1-14.

Corrêa AD, Miranda Filho N, Siqueira- Batista R, Silva Reis da CL, Vahia- Loureiro A, Huggins DW. Epidemiologia. Moléstia de Chagas. Rio de Janeiro: Cultura Médica; 1996. p. 16-38.

Costa JM, Jurberg J, Barth MO. Estudos morfológicos de Cavernicola lenti Barreto \& Arias, 1985 (Hemiptera, Reduviidae, Triatominae). Mem Inst Oswaldo Cruz $1991 ; 86(2): 247-263$.

Costa J. Distribuição e caracterização de diferentes populações de Triatoma brasiliensis Neiva, 1911 (Hemiptera, reduviidae, Triatominae). Cad Saúde Pública 2000; 16 Supl 2: 93- 95.

Costa Neto PLO. Estatística. São Paulo; Edgard Blucher; 1977.

Daly HV. Insects Morphometrics. Ann Rev Entomol 1985; 30:415-38.

Dean AG, Dean JA, Coulumbier D, Brendel KA, Smith DC, Burton AH et al. Epi info, versão 6.04B. São Paulo: Imprensa Oficial do Estado S. A. IMESP, 1994.

Dias E. Estudos sobre o Schizotrypanum cruzi. Mem Inst Oswaldo Cruz 1934; 28: 1-110.

Dias JCP. Control of Chagas disease in Brazil. Parasitology Today 1987; 3(11): 336-341. 
Dias JCP. Epidemiologia. In: Brener Z, Andrade ZA, Barral- Netto $M$. Trypanosoma cruzi e Doença de Chagas. $2^{\mathrm{a}}$ ed. Rio de Janeiro: Guanabara Koogan S. A.; 2000. p. 48-74.

Dias JCP. Doença de Chagas, ambiente, participação e Estado. Cad Saúde Pública 2001; 17 Supl: 165-169.

Dias JCP. Chagas disease and blood transfusion in endemic areas. In: Wendel S, Brener Z, Camargo ME, Rassi A. Chagas disease (American Trypanosomiasis): its impact on transfusion and clinical medicine. ISBT Brazil 92: São Paulo; 1992.

Dias JCP, Silveira AC. Situação atual da doença de Chagas no Brasil. Rev Soc Bras Med Trop 1996; 29 Sup 2: 19-21.

Diotaiuti L, Dias JCP. Ocorrência e biologia de Rhodnius neglectus Lent, 1954 em macaubeiras da periferia de Belo Horizonte, Minas Gerais. Mem Inst Oswaldo Cruz 1984; 79: 239-301.

Diotaiuti L, Paula R de, Falcão PL, Dias JCP. Avaliação do programa de controle vetorial da doença de Chagas em Minas Gerais, Brasil, com referência especial ao Triatoma sordida. Bol San Panam 1995; 118(3):211-219.

Dujardin JP, Bermudez H, Schofield CJ. The use of morphometrics in entomological surveillance of silvatic foci of Triatoma infestans in Bolivia. Acta Tropica 1997a; 66: $145-153$.

Dujardin JP, Bermudez H, Casini C, Schofield CJ, Tibayrenc M. Metric differences between silvatic and domestic Triatoma infestans (Heteroptera: Reduviidae) in Bolivia. J Med Entomol 1997b; 34(5): 544- 551. 
Dujardin JP, Torrez EM, Le-Pont F, Hervas D, Sossa D. Isozymic and metric variation in the Lutzomyia longipalpis complex. Med Vet Entomol 1997c; 11: 394400.

Dujardin JP, Forges G, Torrez M, Martinez E, Cordoba C, Gianella A. Morphometrics of Panstrongylus rufotuberculatus in Bolivia. Ann Trop Med Parasitol 1998; 92(2): 219-228.

Dujardin JP. Introducción a la morfometria com énfasis en Triatominae Phlebotominae. [Monograph on line]. 1999a. Available in <URL: http://eclat.fcien.edu.uy>. [2002 Maio 31].

Dujardin JP, Steindel M, Chavez T, Machane M, Schofield CJ. Changes in the sexual dimorphism of Triatominae in the transition from natural to artificial habitats. Mem Inst Oswaldo Cruz 1999b; 94: 565- 569

Dujardin JP, Chavez T, Moreno JM, Machane M, Noireau F, Schofield C. Comparison of isoenzyme electrophoresis and morphometric analysis for phylogenetic reconstruction of the Rhodniini (Hemiptera: Reduviidae: Triatominae). J Med Entomol 1999c; 36: 653-659.

Espínola HN. Nota sobre diferenças sexuais em formas imaturas de Triatominae (Hemiptera, Reduviidae). Rev Bras Biol 1966; 26(3): 263-267.

Forattini OP, Rabello EX, Castanho MLS, Patoli DG. Aspectos ecológicos da tripanossomose americana. I. Observações sobre o Panstrongylus megistus e suas relações com os focos naturais da infecção, em área urbana da cidade de São Paulo, Brasil. Rev Saúde Pública 1970; 4: 19-30.

Forattini OP, Ferreira AO, Rocha e Silva EO, Rabello EX. Aspectos ecológicos da tripanossomíase americana. XII. Variação regional da tendência de Panstrongylus megistus à domiciliação. Rev Saúde Pública 1978; 12: 209- 33. 
Forattini OP. Biogeografia, origem e distribuição da domiciliação de triatomíneos no Brasil. Rev Saúde Pública 1980; 14(3): 265- 299.

Galindez-Girón I, Valderrama A, Anez N, Márquez V, Torres E, Madrid S, Barazarte R, Márquez J, Gonzalez R. Algunos estudios morfométricos en los Triatominae. I. Rhodnius prolixus y Rhodnius robustus (Hemiptera, Reduviidae). Entomol Vect 1994; 1(3): 99-111.

Galindez-Girón I, Torres E, Matos E, Araújo V, Márquez J, Barazarte R, Araque L, Castillo L de. Estúdio morfométrico preliminar de Rhodnius robustus Larrousse, 1927 (Hemiptera, Reduviidae, Triatominae), del occidente de Venezuela. Entomol Vect $1997 ; 4(4)$ : 99-110.

Gonçalves TCM, Lent H, Almeida JR. Estudo anatômico e morfométrico dos folículos testiculares de algumas espécies de Triatominae (Hemiptera: Reduviidae). Mem Inst Oswaldo Cruz 1987; 82(4): 543-550.

Gonçalves TCM, Oliveira E de, Dias LS, Almeida MD, Nogueira WO, Pires FDA. An. Investigation on the ecology of Triatoma vitticeps (Stal, 1859) and its possible role in the transmission of Trypanosoma cruzi in the locality of Triunfo, Santa María Magdalena. Municipal District, State of Rio de Janeiro, Brazil. Mem Inst. Oswaldo Cruz 1998; 93(6): $711-717$.

Gorla DE, Jurberg J, Catalá SS, Schofield CJ. Systematics of Triatoma sordida, T. guasayana and T. patagonica (Hemiptera, Reduviidae). Mem Inst Oswaldo Cruz 1993; 88(3): 379- 385.

Gorla DE, Dujardin JP, Schofield CJ. Biosystematics of old world Triatominae. Acta Tropica 1997; 63: 127- 140. 
Harry M, Galindez I, Cariou ML. Isozyme variability and differentiation between Rhodnius prolixus, $R$. robustus and $R$. pictipes, vectors of Chagas disease in Venezuela. Med Vet Entomol 1992; 6: 37-43.

Harry M. Isozymic data question the specific status of blood- sucking bugs of genus Rhodnius, vectors of Chagas' disease. Trans R Soc Trop Med Hyg 1993; 87: 492.

Harry M. Morphometric variability in the Chagas' disease vector Rhodnius prolixus. J. Genet 1994; 69: 233-250.

James FC, McCulloch CE. Multivariate analysis in ecology and systematics: panacea or Pandora's box? Ann Rev Ecol Syst 1990; 21: 129-66.

Jaramillo C, Montaña MF, Castro LR, Vallejo GA, Guhl F. Differentiation and genetic analysis of Rhodnius prolixus and Rhodnius colombiensis by DNA and RAPD amplification. Mem Inst Oswaldo Cruz 2001; 96(8): 1043-1048.

Jurberg J, Fagundes LM de , Barth OM. Estudo morfológico de ovos e ninfas de Dipetalogaster maximus (Uhler, 1894) (Hemiptera, Reduviidae, Triatominae). Mem Inst Oswaldo Cruz 1993; 86(2): 269- 283.

Jurberg J, Campos P. Morfologia de huevos e ninfas de Triatoma vitticeps (Stal, 1859) (Hemiptera - Reduviidae). Entomol Vect 1995; 2(1): 9-22.

Jurberg J, Galvão C. Hermanlentia n. gen. da Tribo Triatomini, com um rol de espécies de Triatominae (Hemiptera, Reduviidae). Mem Inst Oswaldo Cruz 1997; 92: 181-185.

Jurberg J. Noventa anos da descoberta da doença de Chagas e a criação do Centro de Referência em Taxonomia de Triatomíneos. Entomol Vect 1999; 6(4): 315-322. 
Jurberg J, Carcavallo RU, Lent H. Panstrongylus sherlocki sp.n. do Estado da Bahia, Brasil (Hemiptera, Reduviidae, Triatominae). Entomol Vector 2001; 8(2): 261-274.

Jurberg J, Silva MBA, Galvão C, Silva- Rocha D da, Barbosa HS, Carcavallo RU. Descrição dos ovos e dos estádios ninfais de Triatoma jurbergi Carcavallo, Galvão \& Lent, 1998 vistos através de microscopia óptica e eletrônica de varredura (Hemiptera, Reduviidae). Mem Inst Oswaldo Cruz 2002; 97(2): 209- 216.

Lent H, Wygodzinsky P. Revision of the Triatominae (Hemiptera, Reduviidae), and their significance as vectors of Chagas' disease. Bull Amer Museum Nat Hist 1979; 163(3): 123-520.

Lent H, Jurberg J. O Gênero Rhodnius Stal, 1859, com um estudo sobre a genitália das espécies (Hemiptera- Reduviidae- Triatominae). Rev Bras Biol 1969; 29(4): 487- 560 .

Lent $\mathrm{H}$, Jurberg J. Estudo comparativo da genitália externa masculina de seis espécies de Triatoma Laporte, 1832 que mais freqüentemente habitam o domicílio humano no Brasil (Hemiptera, Reduviidae). Rev Bras Biol 1978; 38(4): 931 - 944.

Lent H, Jurberg J. Comentários sobre a genitália externa masculina em Triatoma Laporte, 1832 (Hemiptera, Reduviidae). Rev Bras Biol 1980; 40(3): 611 - 627.

Linhares AX. Vetores do Trypanosoma cruzi. Rev Patol Trop 2000; 29Supl: 83- 89.

Lucena DT de. Ecologia dos Triatomíneos do Brasil. Rev Malar Doenças Trop $1959 ; 11(1): 577-635$.

Marcondes CB. Entomologia médica e veterinária. São Paulo: Atheneu; 2001. 
Mascarenhas BM. Triatomíneos da Amazônia. Morfometria do ovo de Rhodnius brethesi Matta, 1919 (Hemiptera, Triatominae). Acta Amazônica 1982; 12(3):66164.

Mathsoft WA. S-PLUS. User's Guide, Data Analysis Products Division. Seattle; 2000.

Matias A, Riva JX de la, Torrez M, Dujardin JP. Rhodnius robustus in Bolivia identified by its wings. Mem Inst Oswaldo Cruz 2001; 96(7): 947-950.

Monteiro LR, Reis SF dos. Princípios de morfometria geométrica. Ribeirão Preto: Holos Editora; 1999. 188p.

Monteiro FA, Wesson DM, Dotson EM, Schofield CJ, Beard CB. Phylogeny and molecular taxonomy of the Rhodnini derived from mitochondrial and nuclear DNA sequences. Am J Trop Med Hyg 2000; 62(4): 460-465.

Noireau F, Bastrenta B, Catalá S, Dujardin JP, Panzera F, Torrez M, Perez R, Galvão C, Jurberg J. Sylvatic population of Triatoma infestans from the Bolivian Chaco: from field collection to characterization. Mem Inst Oswaldo Cruz 2000; 95 Supl $1: 119-122$.

Organización Mundial de la Salud. Control de la enfermedad de Chagas.Ginebra; 1991. (OMS- Series Inf Tecn, 811).

Papa AR, Jurberg J, Carcavallo RU, Cerqueira RL, Barata JMS. Triatoma sherlocki sp. n. do Estado da Bahia, Brasil (Hemiptera, Reduviidae, Triatominae). Entomol Vector 2002; 9(1): 133-146.

Patterson JS, Schofield CJ, Dujardin JP, Miles MA. Population morphometric analysis of the tropicopolitan bug Triatoma rubrofasciata and relationships with old world species of Triatoma: evidence of new world ancestry. Med Vet Entomol $2001 ; 15: 443-451$. 
Perlowagora-Szumlewicz A, Cruz HN da. Triatominae (Hemiptera, Reduviidae): sex identification in immature forms of vectors of Chagas disease. Rev Inst Med Trop $1972 ; 14(1): 6-11$.

Pinto C. Arthrópodes parasitos e transmissores de doenças. In: Mello P de (Ed.), Tratado de Parasitologia 1930; vol 4: 173- 234.

Ray C. The application of Bergmann's and Allen's rules to the Poikilotherms. J Morphology 1960; 106: 85-108.

Rey L. Tripanossomíase por Trypanosoma cruzi: epidemiologia e controle. In: Bases da Parasitologia Médica. $2^{\mathrm{a}}$ Ed. Rio de Janeiro: Guanabara Koogan S. A. ; 2002. p. 42- 49 .

Ribeiro ALP, Rocha MOC. Forma indeterminada da doença de Chagas. In: Brener Z, Andrade ZA, Barral- Netto $M$. Trypanosoma cruzi e Doença de Chagas. $2^{\text {a }}$ ed. Rio de Janeiro: Guanabara Koogan S. A.; 2000. 246-265.

Rosa JA da, Barata JMS, Barelli N. Cerdas Abdominais de espécies de Triatominae, através de Microscopia Eletrônica de Varredura. Mem Inst Oswaldo Cruz 1989; 84 Supl 2: 117.

Rosa JA da, Barata JMS, Barelli N, Santos JFL, Neto FMB. sexual distinction between $5^{\text {th }}$ instar nymphs of six species of Triatominae (Hemiptera, Reduviidae). Mem Inst Oswaldo Cruz 1992a; 87 (2): 257-264.

Rosa JA da, Barata JMS, Barelli N. Spiracles of $5^{\text {th }}$ instar nymphs in six species of Triatominae (Hemiptera, Reduviidae) using scanning electron mycroscopy. Mem Inst Oswaldo Cruz 1992b; 87 (2): 301-302. 
Rosa JA da, Barata JMS, Barelli N. Morphology of abdominal bristles determined by scanning electron microscopy in six species of Triatominae (Hemiptera, Reduviidae). Mem Inst Oswaldo Cruz 1995; 90(4): 487-488.

Rosa JA da, Barata JMS, Cilense M. Description of eight and nineth urosternite of female fifth instar nymphs of five species of Triatoma (Hemiptera, Reduviidae). Bolletino Chemico Farm 1997; 136: 2.

Rosa JA da, Barata JMS, Cilense M, Belda FM. head morphology of $1^{\text {st }}$ and $5^{\text {th }}$ instar nymphs of Triatoma circummaculata and Triatoma rubrovaria (Hemiptera, Reduviidae). Intern J Insect Morph Embryol 1999; 28: 363-375.

Rosa JA da, Barata JMS, Santos JLF, Cilense M. Morfologia de ovos de Triatoma circummaculata e Triatoma rubrovaria (Hemiptera, Reduviidae). Rev Saúde Pública 2000a; 34(5): 538-42.

Rosa JA da, Tres DFA, Santos JLF, Barata JMS. Estudo morfométrico dos segmentos antenais de ninfas e adultos de duas colônias de Triatoma rubrovaria (Blanchard, 1843) (Hemiptera, Reduviidae). Entomol Vect 2000b; 7(3): 255-264.

Santos CM dos, Jurberg J, Galvão C, Rocha DS, Galindez-Girón I. Morphometrics of the genus Panstrongylus Berg, 1879 (Hemiptera, Reduviidae, Triatominae). Mem Inst Oswaldo Cruz 1999; 94 Supl 2: 252.

Schofield CJ, minter DM, Tonn RJ. Vector control series. XIV. The triatomine bugs- biology and control. Geneva: World Health Organization; 1987 (WHO/VBC/87.941).

Schofield CJ. Triatominae. Biología y control. West Sussex: Eurocommunica Publications; 1994.

Schofield CJ. Biosystematics and evolution of the Triatominae. Cad Saúde Pública 2000; 16 Supl 2: 89-92. 
Schreiber G, Penalva F, Carvalho HC de. Morfologia comparada dos túbulos testiculares e sistemática dos Triatominae (Hemipt. Reduv.). Cien Cult 1968; 20(3): 640-41.

Sherlock IA. Vetores. In: Brener Z, Andrade ZA, Barral- Netto M. Trypanosoma cruzi e Doença de Chagas. Rio de Janeiro: Guanabara Koogan S. A.; 1979. p. 4288.

Sherlock IA, Carcavallo RU, Galindez-Girón I. Lista de infecções naturais e experimentais por flagelados em diversas espécies de triatomíneos. In: Carcavallo RU, Galindez- Girón I, Martínez A, Jurberg J, Lent H. Atlas of Chagas disease vectors in the Americas. Rio de Janeiro: Fiocruz; 1997. v. 1. p 289-298.

Sherlock IA. Vetores. In: Brener Z, Andrade ZA, Barral- Netto M. Trypanosoma cruzi e Doença de Chagas. $2^{\mathrm{a}}$ ed. Rio de Janeiro: Guanabara Koogan S. A.; 2000. p. 21-40.

Siegel S. Non parametric statistics for the behavioral sciences. New York: McGraw-Hill; 1956.

Silva MBA, Barbosa HS, Carcavallo RU, Galvão C, Jurberg J. Placas apicais do lábio das ninfas de $1^{0}$ estádio de Triatoma guazu Lent, 1998 (Hemiptera, Reduviidae), vetores da doença de Chagas. Entomol Vect 1999; 6(6): 663- 668.

Silva MBA, Jurberg J, Galvão C, Carcavallo RU. Estudo morfológico e morfométrico de ovos e ninfas de Triatoma guazu Lent \& Wygodzinsky, 1979 (Hemiptera, Reduviidae, Triatominae) vistos por microscopia óptica e eletrônica de varredura. Entomol Vect 2000; 7(3): 311- 334.

Silveira AC. Epidemiologia e controle da doença de Chagas. A Saúde no Brasil 1983; 1(4): 212- 218. 
Silveira AC, Diotaiuti I, Neiva E, Matos CAS, Elias M. Domiciliação de Rhodnius neglectus Lent, 1954, no Estado de Goiás, Brasil. In: X Reunião de Pesquisa Aplicada em Doença de Chagas, Caxambu, 1983.

Silveira AC. Distribuição de triatomíneos capturados no ambiente domiciliar no período de 1975/1983, Brasil. Rev Bras Malar Doenças Trop 1984; 36: 15-312.

Silveira AC, Rezende DF de. Epidemiologia e controle da transmissão vetorial da doença de Chagas no Brasil. Rev Soc Bras Med Trop 1994; 27 Supl 3: 11-22.

Silveira AC. Situação do controle da transmissão vetorial da doença de Chagas nas Américas/ Current situation with Chagas disease vector control in the americas. Cad Saúde Pública 2000; 16 Supl 2:35-42.

Soares RPP, Barbosa SE, Dujardin JP, Schofield CJ, Siqueira AM, Diotaiuti L. Characterization of Rhodnius neglectus from two regions of Brazil using isoenzymes, genitalia morphology and morphometry. Mem Inst Oswaldo Cruz 1999; 94(2): $161-166$.

Solano P, Dujardin JP, Schofield CJ, Romaña C, Tibayrenc M. Isoenzymes as a tool for identification of Rhodnius species. Res Rev Parasitol 1996; 56: 41- 47.

Takeda GKF, Moreira FE, Reaes TB de, Castanho LS. Primeiro encontro de Triatoma tibiamaculata Pinto, 1926 naturalmente infectado por Trypanosoma cruzi, no município de Ubatuba, São Paulo. Rev Inst Med Trop 1976; 18(6):402-209.

Valente VC, Valente SAS, Carcavallo RU, Rocha DS, Galvão C, Jurberg J. Considerações sobre uma nova espécies do gênero Rhodnius Stal, do Estado do Pará, Brasil (Hemiptera, Reduviidae, Triatominae). Entomol Vector 2001; 8(1): 65-80. 
Vinhães MC, Dias JCP. Doença de Chagas no Brasil. Cad Saúde Pública 2000; 16 Supl 2: 7-12.

Wendel S, Brener Z, Camargo ME, Rassi A. Chagas disease (American Tripanosomiasis): its impact on transfusion and clinical medicine. Sociological aspects and modes of transmission. Basic framework: the parasite, its cycles $\&$ reservoirs. São Paulo: ISBT Brazil’ 92- SBHH; 1992.

World Health Organization. Control of Chagas disease. Geneva; 1991. (WHOTechnical Report Series, 811).

World Bank. World development Report 1993. Investing in health. New York: Oxford University Press. 1993.

Zeledon R, Ravinovich JE. Chagas disease: an ecological appraisal with special emphasis on its insect vectors. Ann Rev Entomol 1981; 26: 101-133.

Zeledon R. Vectores de la enfermedad de Chagas y sus características ecofisiológicas. Interciencia 1983; 8(6): 384- 395. 
7. ANEXOS 


\section{ANEXOS}

Anexo I. Diferença entre os Valores Morfométricos das Espécies Segundo Atributos Estudados.

Resultados Obtidos para Análise de Variância Segundo um Fator de classificação. Software Epi Info, Versão $6.04 \mathrm{~b}$

ANOVA For normally distributed data only

LBU1-Largura Basal do $1^{\circ}$ Urotergito

\begin{tabular}{lrrrrr}
\hline Variation & SS & df & MS & F statistic & p-value \\
Between & 117.236 & 11 & 10.658 & 70.699 & 0.000000 \\
Within & 7.236 & 48 & 0.151 & & \\
Total & 124.473 & 59 & & &
\end{tabular}

Bartlett's test for homogeneity of variance

Bartlett's chi square $=16.674 \mathrm{deg}$ freedom $=11$ p-value $=0.117909$

The variances are homogeneous with $95 \%$ confidence.

f samples are also normally distributed, ANOVA results can be used.

LBU2 - Largura Basal do $2^{\circ}$ Urotergito

$\begin{array}{lrrrrr}\text { Variation } & \text { SS } & \text { df } & \text { MS } & \text { F statistic } & \text { p-value } \\ \text { Between } & 227.418 & 11 & 20.674 & 179.647 & 0.000000 \\ \text { Within } & 5.524 & 48 & 0.115 & & \\ \text { Total } & 232.942 & 59 & & & \end{array}$

Bartlett's test for homogeneity of variance

Bartlett's chi square $=12.632 \mathrm{deg}$ freedom $=11 \quad \mathrm{p}$-value $=0.318067$

The variances are homogeneous with $95 \%$ confidence.

If samples are also normally distributed, ANOVA results can be used.

LMAC - Largura Maior da Área Circular

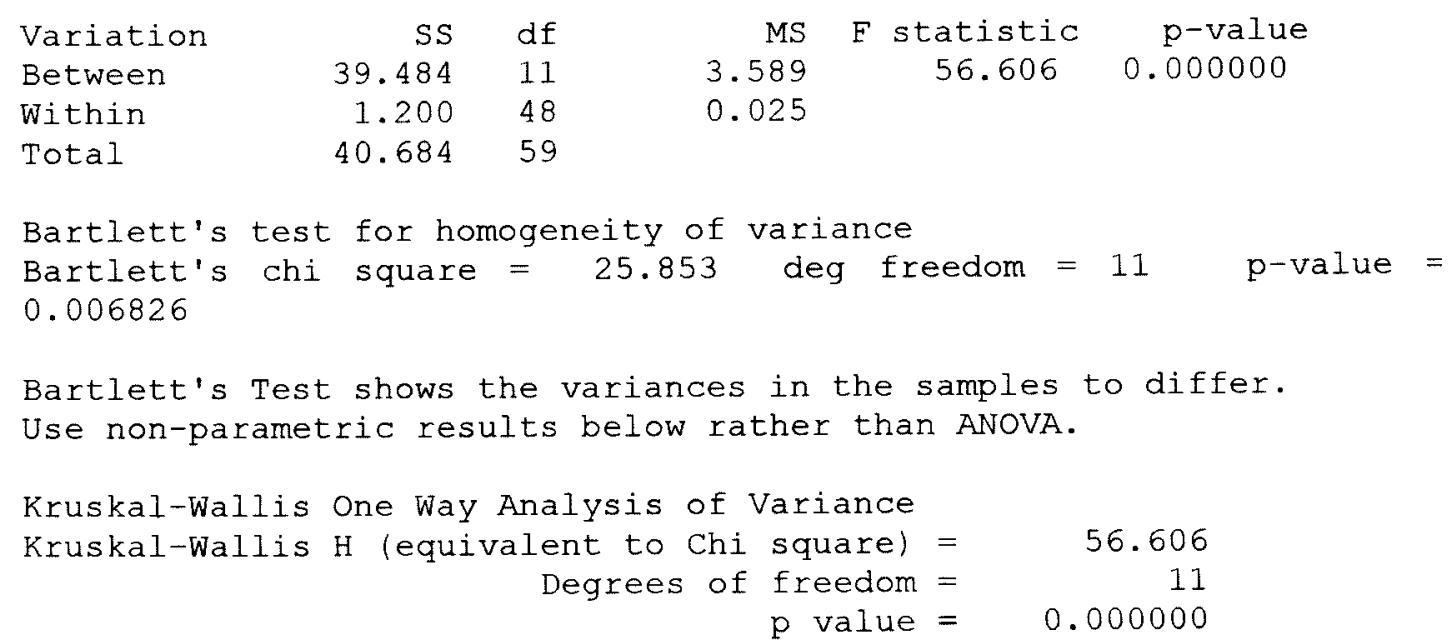




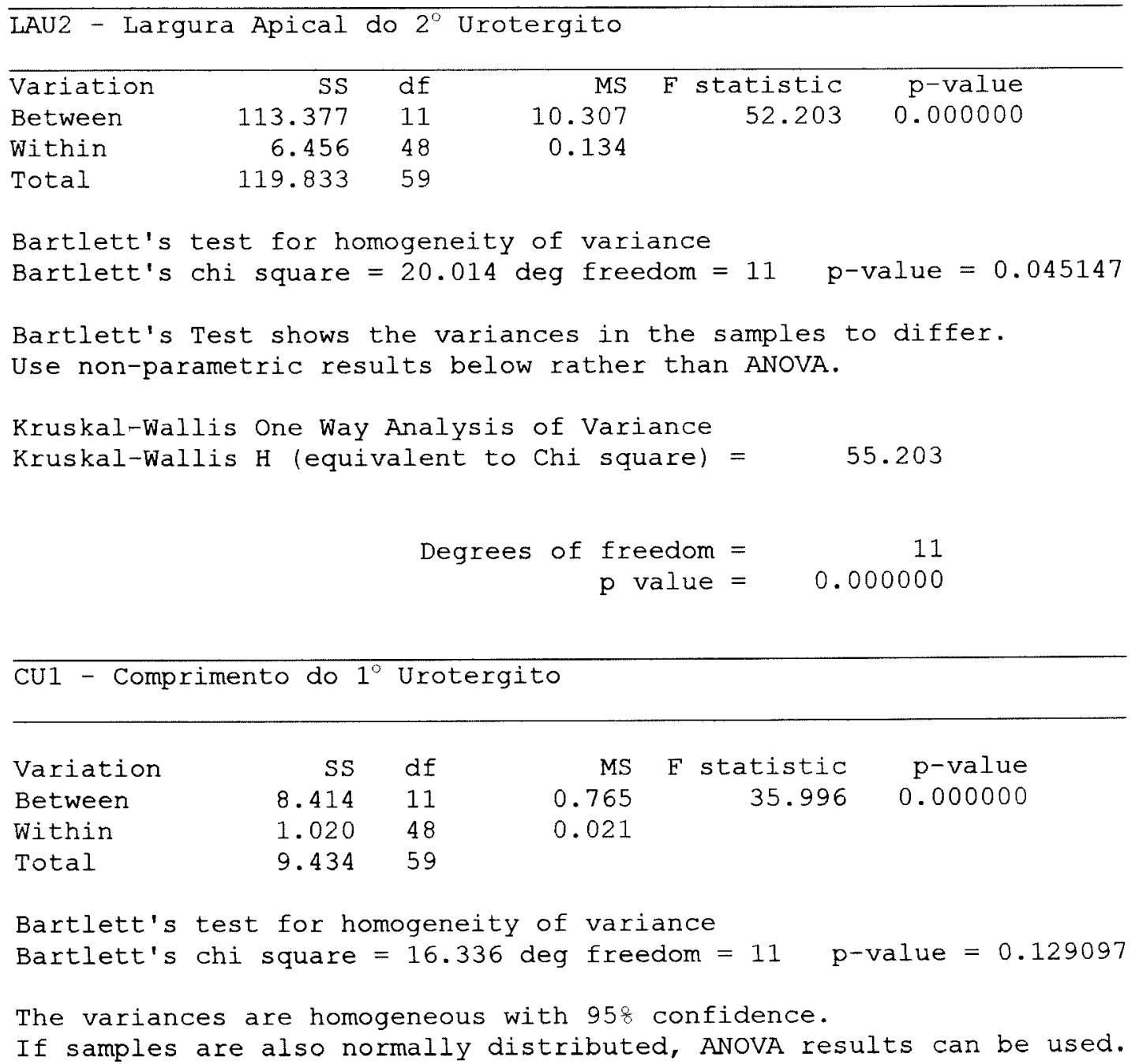

CU2 - Comprimento do $2^{\circ}$ Urotergito

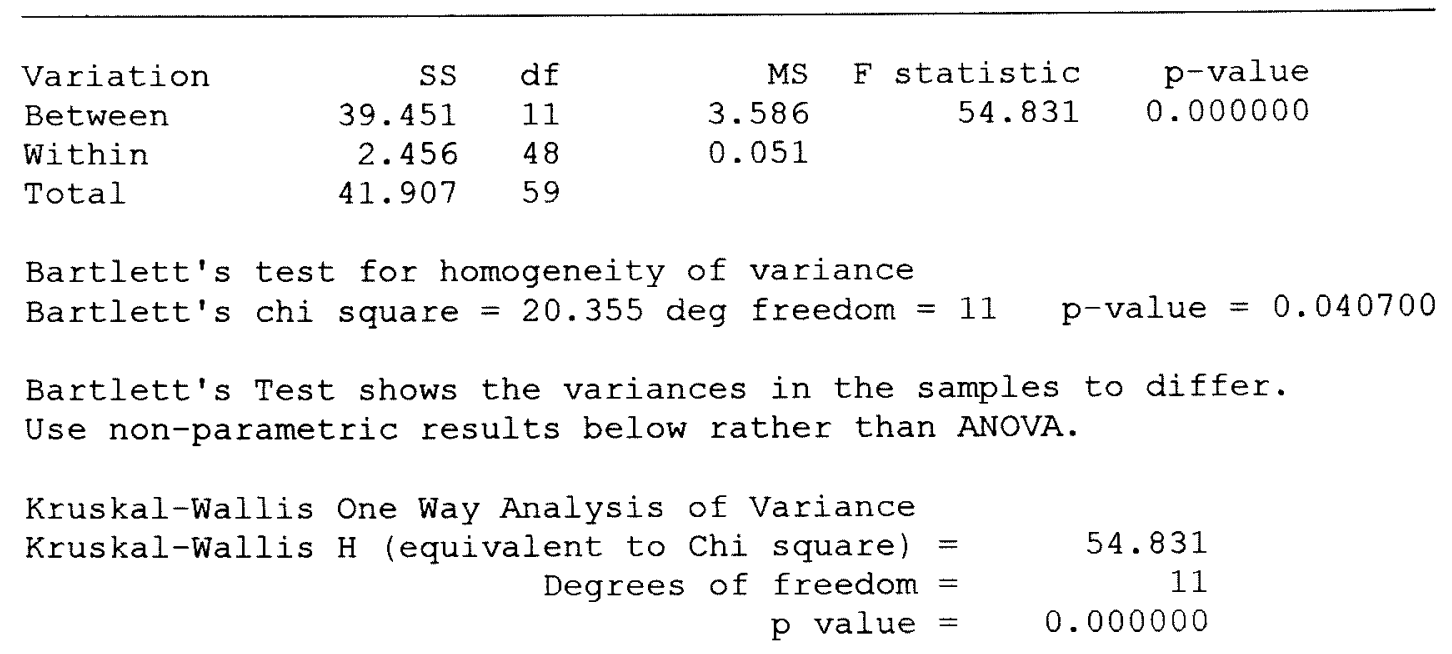

